\title{
61. THE GEOLOGY OF HESS RISE, CENTRAL NORTH PACIFIC OCEAN ${ }^{1}$
}

\author{
Tracy L. Vallier², David K. Rea ${ }^{3}$, Walter E. Dean ${ }^{4}$, Jörn Thiedes, and Charles G. Adelseck ${ }^{6}$
}

\begin{abstract}
The geology of Hess Rise is interpreted from studies of morphology and structure, igneous petrology, sediment lithofacies, seismic stratigraphy, and paleoenvironments.

Hess Rise probably formed at a triple junction, between 116 and $95 \mathrm{~m} . \mathrm{y}$. ago, in the equatorial zone of the southern hemisphere. A large archipelago, formed by volcanism, subsequently moved northward as part of the Pacific Plate and subsided. A Late Cretaceous-early Tertiary tectonic and(or) volcanic event created oceanic islands and probably influenced the normal subsidence rate. The lithofacies reflect both the northward movement under various surface water masses of differing productivity and the subsidence history, which influenced calcareous-sediment accumulation and dissolution.

Hess Rise is informally divided into three physiographic or morphologic provinces: northern Hess Rise, the central platform, and southern Hess Rise. Southern Hess Rise is further subdivided into the northwestern ridge, Mellish Bank, and the eastern ridge. The structure of Hess Rise is dominated by normal faults which bound grabens and horsts. The west and south boundaries of the rise are fault scarps. Most faults trend about $345^{\circ}$ on northern Hess Rise, $039^{\circ}$ to $060^{\circ}$ on southern Hess Rise.

Igneous rocks are tholeiitic basalt on northern Hess Rise at Site 464, and trachyte at Site 465 on southern Hess Rise. The tholeiite probably is not a mid-ocean-ridge basalt; more likely it is a transitional basalt erupted during off-ridge volcanism. The trachyte at Site 465 was erupted either in shallow water or subaerially; it represents a late-stage differentiate of alkali-basalt magma. Geochemically, the trachyte is similar to late-stage eruptives on many oceanic islands. The alkali basalt clasts in Upper Cretaceous calcareous ooze at Site 466 probably record a Late Cretaceous-early Tertiary tectonic event that brought old crust above sea level, where it was eroded; alternatively, volcanism may have built the islands.

Cores recovered from Holes 464, 310, 310A, 465, 465A, and 466 (north to south) show three major lithofacies: limestone of mid-Cretaceous (Albian-Cenomanian) age, calcareous ooze and chalk of Late Cretaceous to Quaternary age, and pelagic clay that is Late Cretaceous to Quaternary in age at Site 464 and Eocene in age at Site 310. Minor lithofacies in the carbonates and pelagic clay include siliceous microfossils and chert. The limestone contains as much as $8.6 \%$ by weight of organic carbon. The organic-carbon-rich sediments apparently were deposited along the sides of Hess Rise, above the $\mathrm{CCD}$ and within a mid-water oxygen minimum, as the rise crossed the highly productive equatorial divergence.

Surface sediments are influenced by present-day near-surface water-mass productivity and the depth of deposition. Above about 3000 meters calcareous ooze is deposited, and below about 4000 meters pelagic clay is dominant. Between 3000 meters and 4000 meters, greater clay contents correlate with increased water depth.

The seismic stratigraphy interpreted from single-channel seismic-reflection records can be correlated with the lithofacies. Three major acoustic units apparently vary in age, composition, thickness, and geographic distribution. The lowest acoustic unit generally is acoustically opaque; it corresponds to volcanic basement. In places, however, the top parts of this unit may be well-lithified limestone or chert. The middle acoustic unit, in general strongly layered acoustically, is Albian and Cenomanian limestone, chalk, and chert on southern Hess Rise and Albian and Cenomanian chert, chalk, limestone, and claystone on northern Hess Rise. The middle unit probably is Albian to at least lower Tertiary chalk, chert, and nannofossil ooze on the central platform. The upper acoustic unit is weakly stratified to acoustically transparent and corresponds to Upper Cretaceous to Recent nannofossil ooze on southern Hess Rise and to pelagic clay of the same age on northern Hess Rise. On the central platform, it probably corresponds to Eocene to Recent nannofossil ooze, marl, and pelagic clay.
\end{abstract}

\section{INTRODUCTION}

The origins and geologic evolutions of oceanic plateaus still are somewhat enigmatic; no oceanic plateau has been studied in the detail necessary for complete understanding. By necessity, therefore, interpretations of many oceanic plateaus have been based on fragmentary seismic, gravity, magnetic, and lithologic data. It is apparent from the previous interpretations that

\footnotetext{
1 Initial Reports of the Deep Sea Drilling Project, Volume 62.

Initial Reports of the Deep Sea Drilling Project,
U.S. Geological Survey, Menlo Park, California.

${ }_{4}^{3}$ University of Michigan, Ann Arbor, Michigan.

${ }_{5}^{4}$ U.S. Geological Survey, Denver, Colorado.

5 University of Oslo, Oslo, Norway.

${ }^{6}$ Scripps Institution of Oceanography, La Jolla, California.
}

oceanic plateaus have several possible origins, and that their geologic evolutions are closely tied to horizontal and vertical motions of the sea floor.

Oceanic plateaus may have pedestals (basement rocks) of either continental or oceanic affinities. Those with continental pedestals apparently were rifted away from the parent continental masses and subsequently either foundered nearby (e.g., Falkland Plateau and Lord Howe Rise) or were transported long distances from their original locations (e.g., Seychelles platform). Most oceanic plateaus, however, have volcanic pedestals that formed either (1) along mid-ocean spreading ridges, (2) during intra-plate volcanism, caused perhaps by passage over a mantle hot spot, (3) as island arcs along convergent margins, (4) as the result of the tectonic uplift of 
older oceanic crust, perhaps with synchronous volcanism, or (5) as a combination of two or more of the above.

Hess Rise, a prominent topographic feature on the floor of the central north Pacific Ocean (Fig. 1; plates in back pocket of volume), has many characteristics similar to those of other oceanic plateaus. The purpose of this paper is to describe the geology of Hess Rise and to interpret its geologic evolution based mainly on (1) Deep Sea Drilling Project results from Site 310 (Larson, Moberly, et al., 1975) and Sites 464, 465, and 466 (this volume), (2) piston-core descriptions provided by Scripps Institution of Oceanography and Lamont-Doherty Geological Observatory, and (3) single-channel seismic-reflection profiles from DSDP Leg 32 (Larson, Moberly, et al., 1975), Leg 55 (Greene, 1980), and Leg 62 (Rea et al., this volume). Scripps Institution of Oceanography cruise Aries 7 (Davies et al., 1971), and LamontDoherty Geological Observatory cruises Vema 20 and 32 and Conrad 10 (Fig. 2). We also discuss previous studies of ocean-floor magnetics (Hilde, Isezaki, and Wageman, 1976; Hilde, Uyeda, and Kroenke, 1977) to assist our interpretations. Water depths are given in meters, assuming a sound velocity of $1500 \mathrm{~m} / \mathrm{s}$. Emphasis is placed on the origin of Hess Rise and its subsequent tectonic and sedimentary histories. Paleoenvironmental interpretations are based on lithostratigraphic and biostratigraphic records, and on the plate-rotation model of Lancelot (1978).

This paper complements the work of Kroenke and Nemoto, who have a paper in press and one or more in preparation on the geology of Hess Rise. Nemoto and Kroenke (in press) discuss Hess Rise bathymetry, acoustic characteristics, and sediment distribution deduced

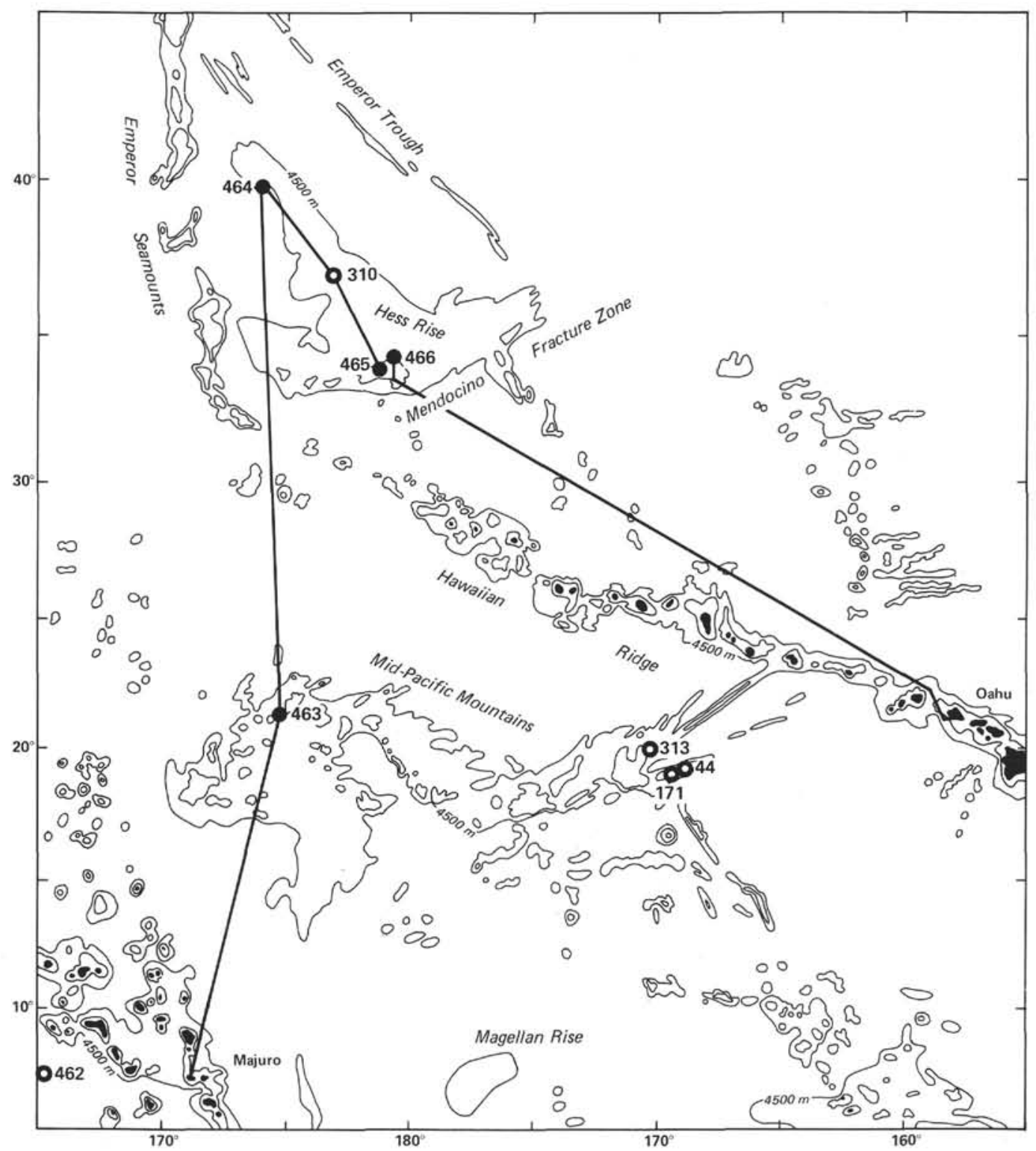

Figure 1. Map showing sites drilled on DSDP Leg 62 . Sites 464, 465, and 466 were drilled on Hess Rise. 


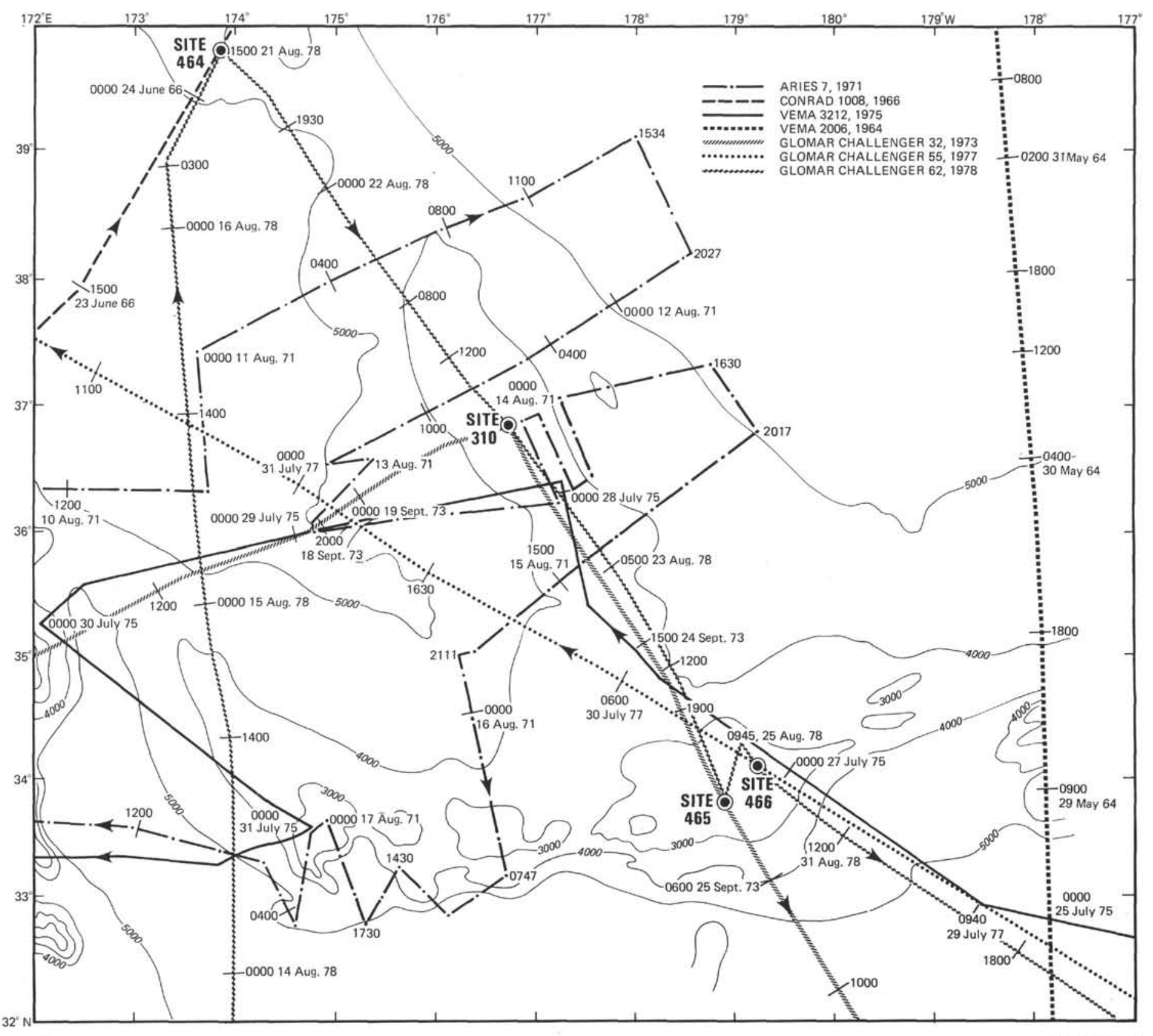


from seismic-reflection profiles collected by the Hawaii Institute of Geophysics (HIG) cruises of the Kana Keoki (1973, 1975, 1976, and 1977), Glomar Challenger cruises 32 and 62, Vema cruise 32, and Aries cruise 7.

\section{MORPHOLOGY AND STRUCTURE}

Hess Rise is in the southern, broader half of a triangular region bounded on the west by the Emperor Seamounts, on the northeast by the Emperor Trough, and on the south by the Mendocino Fracture Zone (Fig. 1). It is apparent that the morphology and structure of Hess Rise are closely related; Figure 3 shows the detailed bathymetry of Hess Rise, and Figure 4 shows the major morphologic trends. For purposes of this paper, we recognize three major morphologic features: southern Hess Rise, the central platform, and northern Hess Rise. Southern Hess Rise, in turn, is further subdivided from west to east into the northwestern ridge, Mellish Bank, and the eastern ridge (Figs. 3 and 4).

Hess Rise proper is shaped somewhat like an inverted $\mathrm{T}$. The leg of the $\mathrm{T}$ is a broad ridge 150 to $250 \mathrm{~km}$ wide and over 1500 meters high that trends northwest on an azimuth of $327^{\circ}$. This ridge, which forms both the central platform and northern Hess Rise, becomes lower and narrower to the north and does not extend much beyond $40^{\circ} \mathrm{N}$. The three morphologic features of southern Hess Rise form the cross-piece of the inverted T. Mellish Bank, the middle and dominant morphologic feature of southern Hess Rise, rises more than 3000 meters above the sea floor to the south. Mellish Bank trends approximately east-west and has a steep southfacing scarp, a broad crestal region, and a gentle north slope.

The eastern ridge of southern Hess Rise is about 100 $\mathrm{km}$ wide and has as much as 2000 meters of relief. Its long axis approximately parallels the Mendocino Fracture Zone and forms the cross-member of a $\mathrm{T}$ whose leg cuts perpendicularly across part of the fracture zone. The southeast extension (Fig. 4) may be part of a seamount chain that trends northwest-southeast between Hess Rise and the Hawaiian Ridge (Fig. 1). The third morphologic feature of southern Hess Rise is the northwestern ridge. Its dimensions and trend are similar to the eastern ridge.

Three distinct structural trends related to the morphologic features appear on Hess Rise (Fig. 4). The most prominent trend $\left(326^{\circ}\right.$ to $\left.332^{\circ}\right)$ is that of the main north arm $\left(327^{\circ}\right)$ and the southeast extension $\left(332^{\circ}\right)$ and northwest ridge $\left(326^{\circ}\right)$ of southern Hess Rise. A second structural trend is defined by the generally east-west features along Mellish Bank. The third structural trend is along the southeastern part of the rise and is roughly parallel to the $060^{\circ}$ trend of the Mendocino Fracture Zone.

Normal faults with offsets up to 500 meters are common on seismic-reflection profiles across Hess Rise (Fig. 5, 2000Z, 21 August to 0330Z, 22 August). These faults occur in stair-step patterns and in graben-and-horst configurations. We were able to identify some major fault trends (Fig. 6) by tracing faults between track lines. It is apparent that the fault trends do not conform exactly to the general trends of the morphologic features discussed above, although there is some constancy in trends on the individual features. For example, the part of Hess Rise north of Site 310 (Figs. 5 and 6) is characterized by a series of normal faults that trend about $345^{\circ}$. This fault pattern does not extend onto southern Hess Rise.

The part of Hess Rise near Sites 465 and 466 appears to be the most complicated sector of the entire region. The main structural features of this area (Fig. 6), from north to south, are (1) two small grabens that trend $050^{\circ}$, (2) the rise crest, which trends $072^{\circ}$, but which may not be fault controlled, (3) a break in slope or a bench halfway down the major south scarp of the rise, trends $055^{\circ}$, (4) the base of the main scarp, which trends $039^{\circ}$, and (5) the Mendocino Fracture Zone, which trends $060^{\circ}$. Significant fault trends, then, range from $039^{\circ}$ to $060^{\circ}$.

The $072^{\circ}$ trend of the crest along southern Hess Rise appears to continue west of Sites 465 and 466 . Most track lines that cross the crest of the rise show a small graben 10 to $20 \mathrm{~km}$ to the north of and paralleling the crest to $174^{\circ} \mathrm{E}$. Structural trends from east to west on the southern margin of Hess Rise change from southwesterly to northwesterly.

On the central platform south of Site 310 is an area of north- to north-northwest-trending structures. Correlation of faults between track lines was more difficult in this region than in the regions either to the north or to the south.

The age (or ages) of faulting on Hess Rise is not clear. Faults cut acoustic basement on most profiles, and it is clear that the faults were active during some of the sediment accumulation. For example (Fig. 5, 0700Z, $22 \mathrm{Au}-$ gust), thicknesses of some sediment units increase near faults. We will show in our discussion of the ages of acoustic units that these units may be as young as Paleogene (mid-Eocene?), suggesting that some faults were active until at least that time.

\section{LITHOLOGY AND SEDIMENT FACIES}

Lithologic units at the four drill sites on Hess Rise are identified by gross lithologic characteristics. The units discussed would be mappable rock-stratigraphic units if they were encountered on land; as such, they correspond to formations, members, and groups. In this section, we describe the rocks and sediments and discuss the lithofacies of the recovered sediment.

Interpretations of the sedimentary history have been influenced by our understanding of the origin of Hess Rise and its subsequent northward movement as part of the Pacific Plate. Hess Rise apparently originated under the biologically productive equatorial water mass and subsequently moved northward under the less-productive center of the North Pacific gyre, and finally under the more-productive subarctic water mass. We assume that Hess Rise subsided according to a normal-subsidence curve (Detrick et al., 1977) as the Pacific Plate moved northward and cooled. However, this gradual subsidence may have been interrupted in the Late Cretaceous or early Tertiary by tectonism and(or) volcanism. 


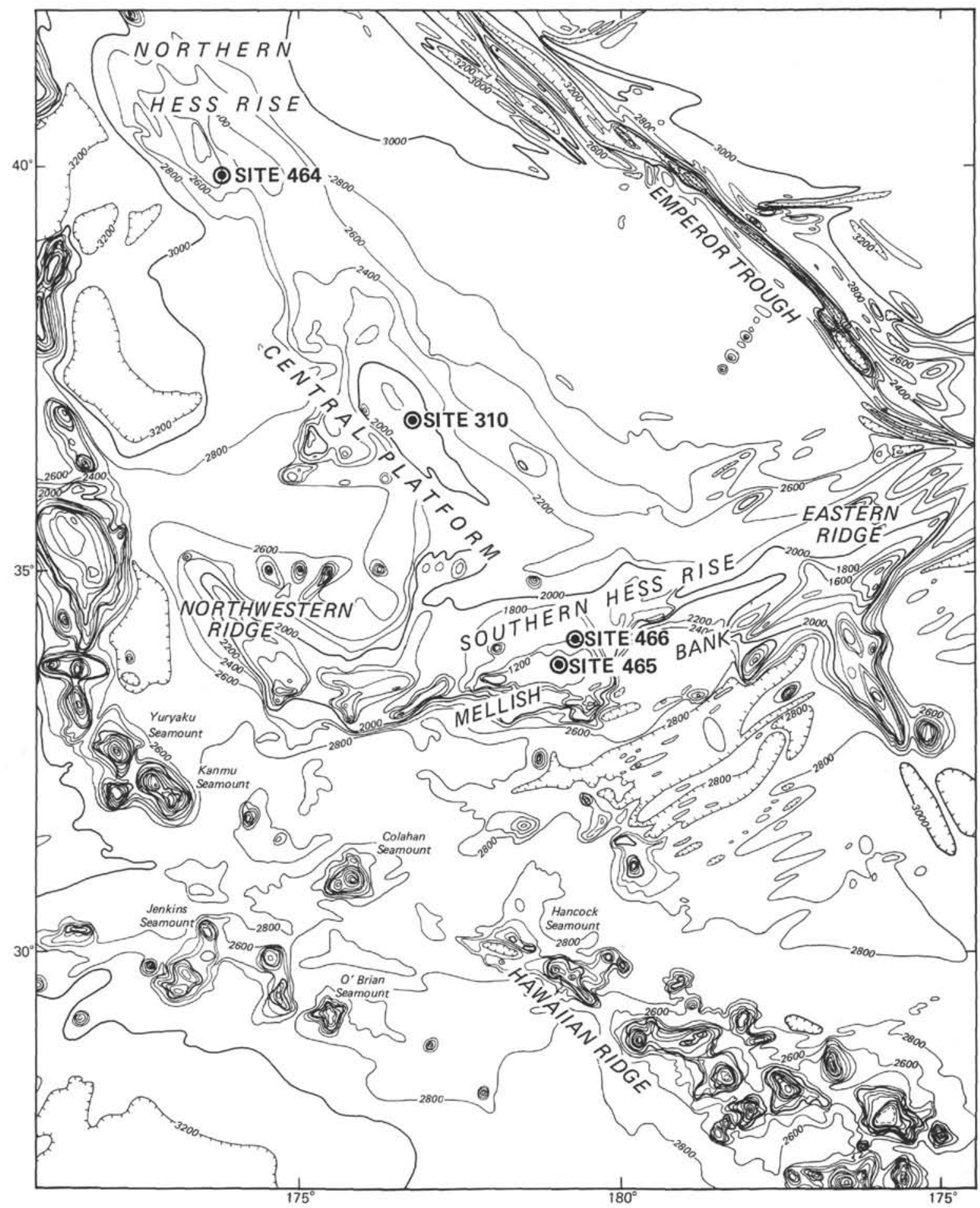

Figure 3. Topographic map of Hess Rise (Chase et al., 1971), showing locations of DSDP Sites 310, 464, 465, and 466. Major physiographic features are shown. Bathymetry in meters is given in Chase et al. (this volume).

\section{Lithologic Units at DSDP Sites}

The lithologic units at Site 310 (Larson, Moberly, et al., 1975) and Sites 464,465 , and 466 (this volume) are briefly reviewed in this section, in order to establish a framework for later discussions of lithofacies and seismic (acoustic) units. Rock-stratigraphic (Fig. 7) and time-rock-stratigraphic (Fig. 8) columns show the lithologies and ages of units recovered and the major lacunas.

Site 465 was drilled on southern Hess Rise at 2161 meters water depth and reached $\mathbf{4 7 6}$ meters sub-bottom. Igneous basement consisting of deeply weathered trachyte was cored in Hole 465A between sub-bottom depths of 411.7 and 476 meters. The volcanic rocks 


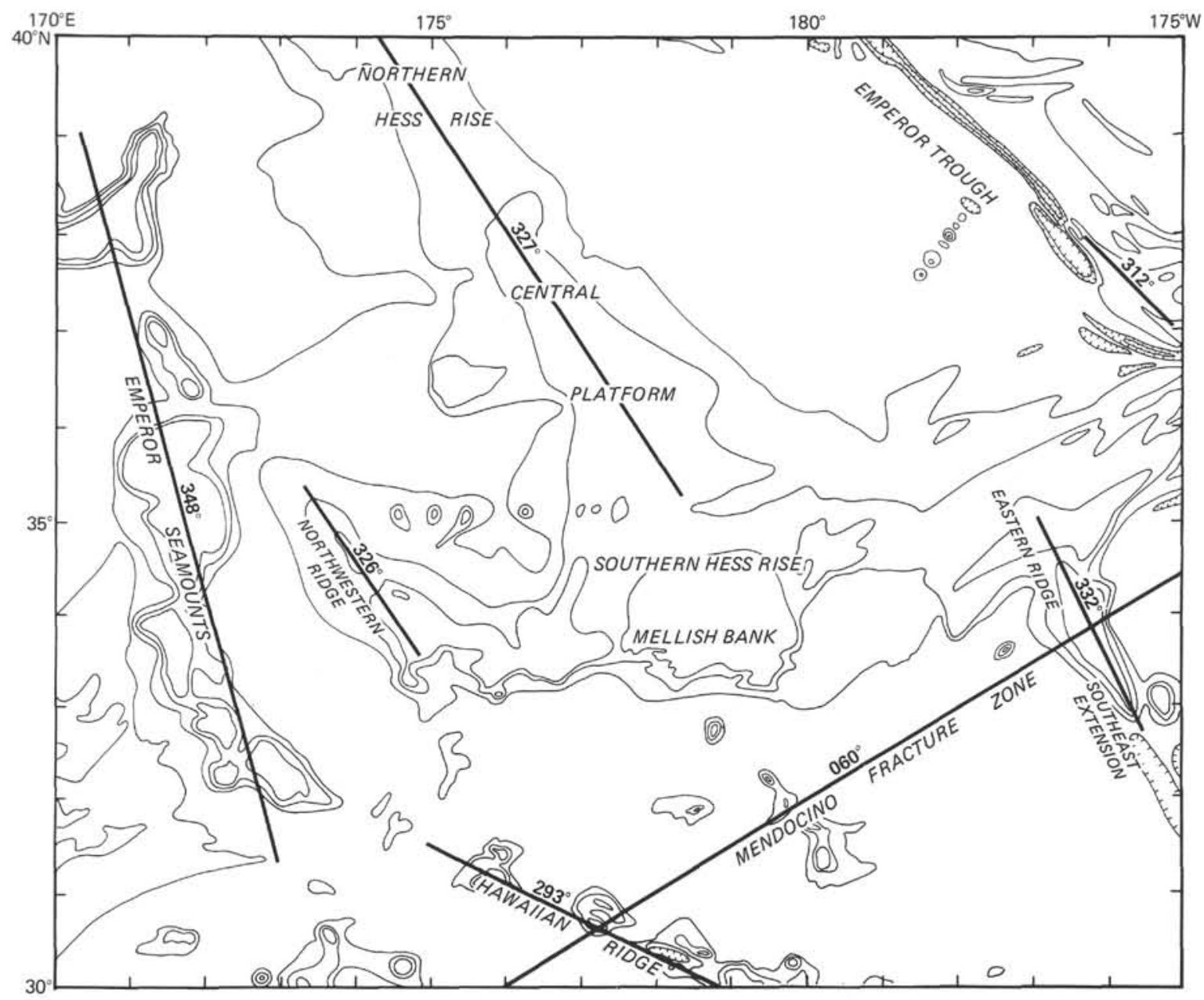

Figure 4. Trends of major morphologic features on and near Hess Rise.

underlie Albian limestone and were erupted either subaerially or in very shallow water (Seifert et al., this volume). The trachyte is overlain by two major sediment units (Fig. 7). Unit II (276-411.7 m sub-bottom) consists of upper Albian and Cenomanian laminated limestone that shows evidence of current scour and redeposition in the beds that directly overlie the trachyte. Concentrations of organic carbon in this limestone unit reach $8.6 \%$, and are usually higher than $2 \%$ (Dean et al., this volume). The overlying sediment (Unit I, $276 \mathrm{~m}$ thick) consists of Coniacian to Pleistocene carbonate ooze with intercalated chert. Hiatuses occur from early Cenomanian to late Coniacian, from Santonian to late Campanian, and from Paleocene to Pliocene (Fig. 8). There may be a hiatus of short duration in the Maastrichtian (Boersma, this volume). The sediment in Unit I reflects a slowly deepening, quiet depositional environment under a highly productive surface water mass. The only significant lithologic change across the Cretaceous/ Tertiary boundary is the occurrence of black pyrite aggregates above the boundary, within the otherwise homogeneous nannofossil ooze of Unit I. Geochemically, however, the sediment above the boundary is marked by increases in many trace elements in the ooze (Dean, this volume), including iridium and gold (Michel et al., this volume). These data lend support to the asteroid theory of mass extinctions at the Cretaceous/ Tertiary boundary (Alvarez et al., 1980; Ganapathy, 1980; Smit and Hertogen, 1980). All sediments recovered at Site 465 represent pelagic carbonate accumulation, which suggests that this part of southern Hess Rise has been above the CCD at all times. Boersma (this volume), judging from benthic-foraminifer data, suggests a gradual deepening from upper slope to lower bathyal $(>1500 \mathrm{~m})$ depths between the Albian and Maastrichtian.

Site 466 is on southern Hess Rise, about $50 \mathrm{~km}$ northeast of Site 465 , at 2665 meters water depth. Subbottom penetration was 312 meters, and igneous basement was not reached. The sedimentary section was subdivided into two major lithologic units, which contains at least three, and possibly four, hiatuses (Figs. 7 and 8). The oldest strata cored (Unit II) consist of 66 meters of upper Albian olive-gray nannofossil chalk and limestone containing up to $8.1 \%$ organic carbon. This unit is correlative with the upper Albian and Cenomanian organic-carbon-rich limestone cored at Site 465. The overlying nannofossil ooze of Unit $\mathrm{I}$ is Turonian to Pleistocene in age. An upper Albian (or Cenomanian) to Turonian hiatus marks the boundary between Units I 

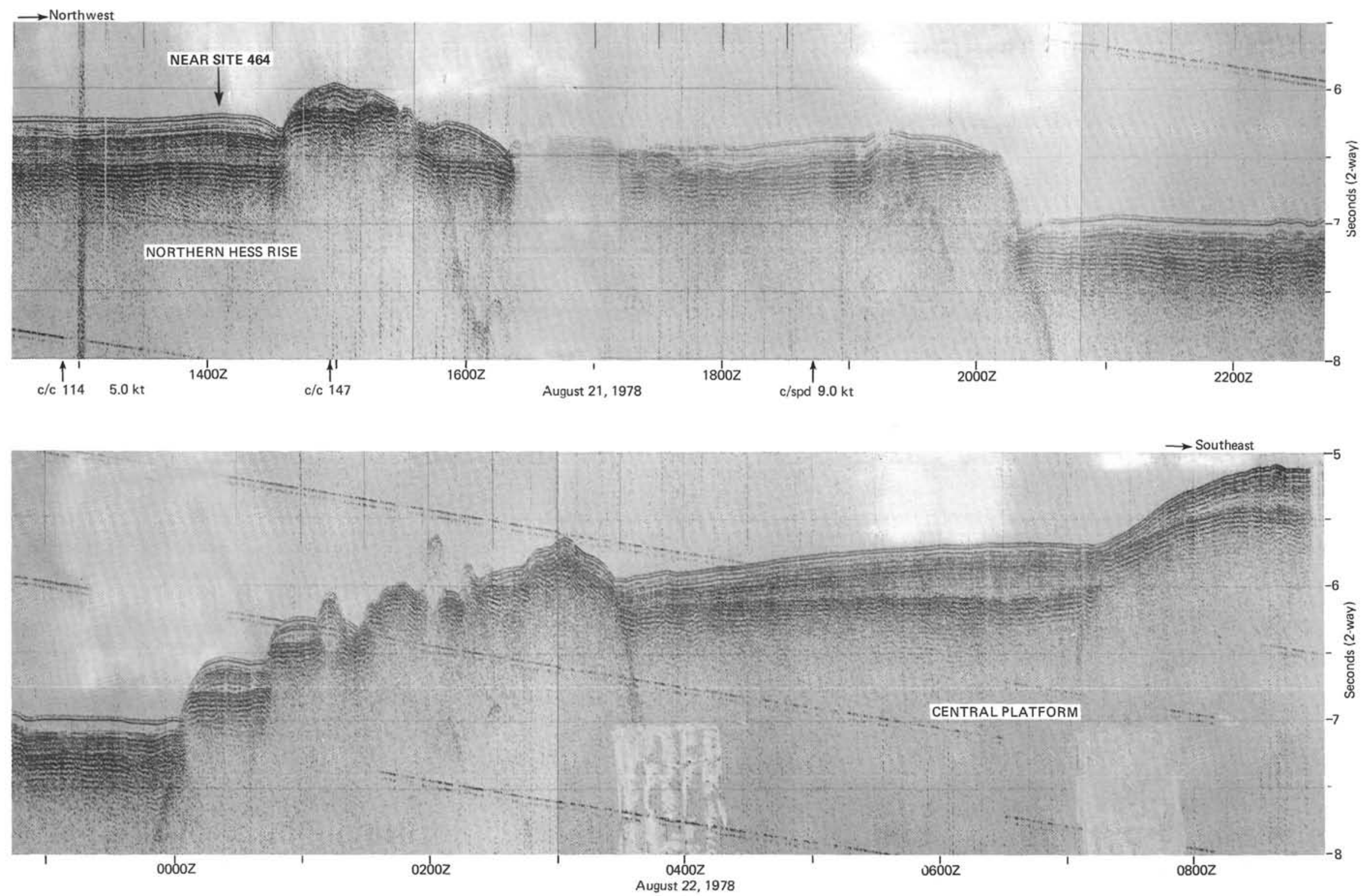

Figure 5. Glomar Challenger five-second sweep seismic record, DSDP Leg 62, from Site 464 southward across the northern part of the central platform of Hess Rise. Graben is apparent along record between $2000 \mathrm{Z}$ and $0000 \mathrm{Z}$. 


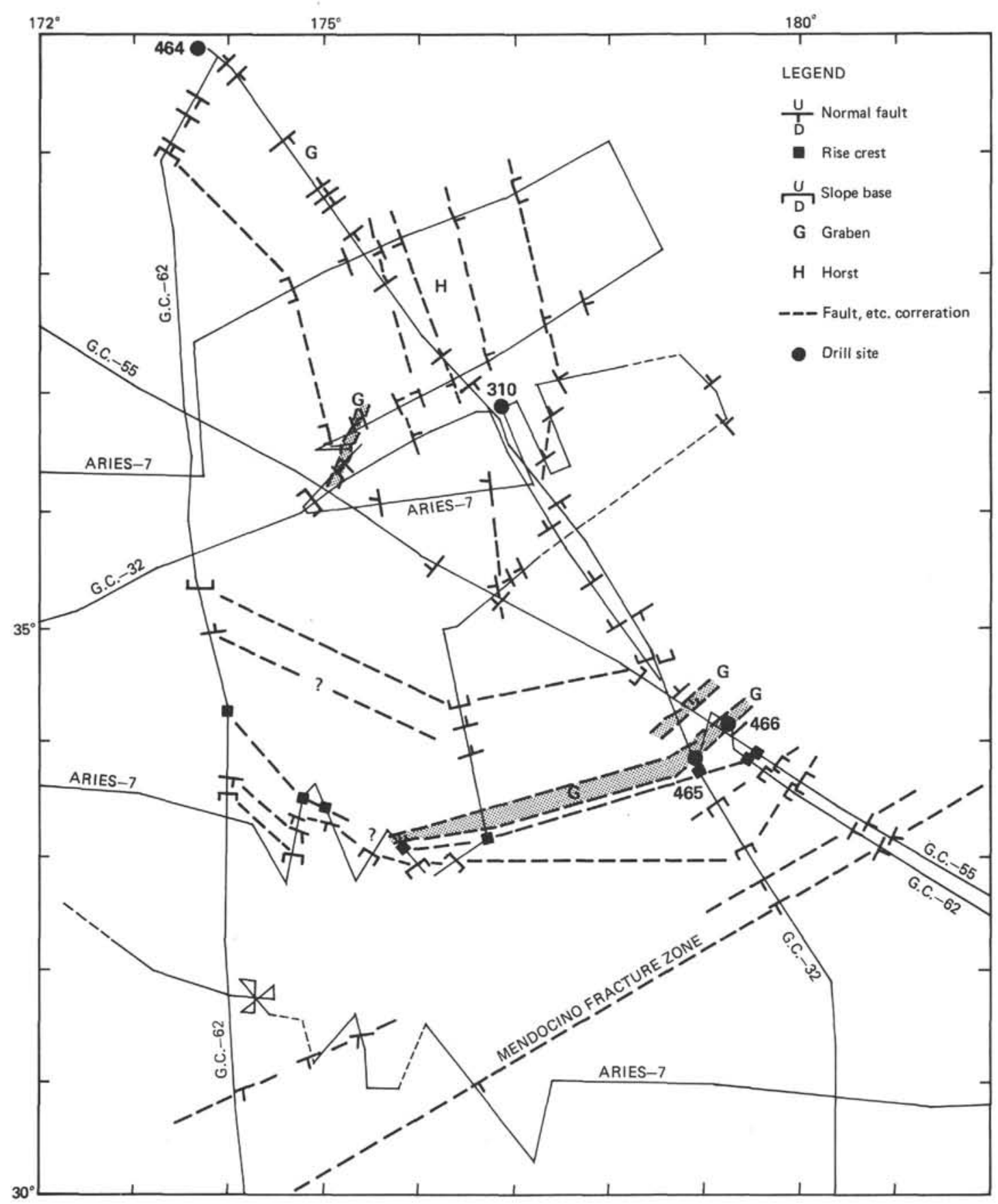

Figure 6. Structural geology of Hess Rise, showing normal faults, major slope breaks, DSDP sites, and the southern crest of Hess Rise. Tentative fault correlations are shown by dashed lines.

and II. Hiatuses of Santonian to early Campanian, early Maastrichtian to middle Eocene, and Oligocene to early Pliocene ages occur within Unit I. The upper 66 meters of sediment are Plio-Pleistocene in age.

Pebbles of altered alkali basalt found in the nannofossil ooze of the lower sub-unit of Unit I suggest either that tectonism raised basement or that additional island volcanism occurred. The date of this event is difficult to determine because of poor recovery and intense mixing of sediment. The first basalt pebbles encountered were in a drilling breccia of Core 10 , mixed with fragments of chert, Inoceramus shells, and a pebble of hematite; mid- dle Eocene nannofossil ooze coated some of the pebbles and fragments. Fragments of chert and abundant pebbles of basalt, mixed with nannofossil ooze of lower Maastrichtian to upper Campanian age, were recovered in Cores 11,12 , and 14 . Two basalt pebbles were recovered in Core 17, and one basalt pebble was recovered in each of Cores 19, 20, 27, 28, and 29. Vallier et al. (this volume) conclude that the pebbles were deposited during the Late Cretaceous (late Campanian to early Maastrichtian), judging from the concentration of pebbles in Cores 11 through 14 . They also suggest, however, that these pebbles are associated with the early 
Maastrichtian to middle Eocene unconformity and may have been subsequently incorporated into Cretaceous material as down-hole contamination during drilling and coring. Regardless of exact timing, the alkali-basalt pebbles record a major event on southern Hess Rise when nearby volcanic outcrops were eroded and the rounded clasts were transported to Site 466 .

Site 310 (Larson, Moberly, et al., 1975) is on the central platform of Hess Rise, at 3516 meters water depth; it was drilled to 352.5 meters sub-bottom. Igneous rocks were not penetrated. The sediment sequence was divided into four lithologic units (Figs. 7 and 8). Unit IV (128$352.5 \mathrm{~m}$ sub-bottom) consists of upper Albian (or lower Cenomanian) to Campanian chert, nannofossil ooze, and nannofossil chalk, with some porcellanite and pelagic shale, Unit III (95-128 m sub-bottom) consists of nannofossil ooze of late Campanian and early Maastrichtian age that underlies a Maastrichtian to lower Eocene unconformity. Unit II (79-95 m sub-bottom) consists of zeolitic nannofossil ooze and nannofossil-bearing zeolitic pelagic clay. An unconformity within Unit II separates the pelagic clay of probable early and middle Eocene age from the lower Oligocene nannofossil ooze. Unit I (0-79 $\mathrm{m}$ sub-bottom) is a radiolarian-bearing nannofossil ooze of middle Miocene to Pleistocene age.

Site 310 apparently remained above the local CCD through most of its history. However, zeolitic pelagic clay in lithologic Unit II indicates that the CCD rose between the early Maastrichtian and early Eocene, but subsided below the site by the middle Eocene. Site 310 was at an equatorial position under a high-productivity surface water mass in the late Albian to Cenomanian, according to the plate-rotation model of Lancelot (1978). An inflection point in the sedimentation-rate curve at about 70 m.y. marks the beginning of the site's transit under the mid-latitude low-productivity zone. Increased sedimentation rates in the Neogene and Pleistocene suggest a return of the site to a position under high-productivity surface water.

Site 464 was drilled on the northern flank of Hess Rise, at 4637 meters water depth; drilling reached $\mathbf{3 0 8 . 5}$ meters sub-bottom. Altered tholeiitic basalt was recovered from the base of the hole (Seifert et al., this volume). The sediment column is $\mathbf{3 0 7 . 6}$ meters thick and was subdivided into three lithologic units (Fig. 7). The lower unit (Unit III) is a thick $(218.6 \mathrm{~m})$ sequence of lower Albian (or upper Aptian) to Cenomanian chalk, limestone, marlstone, chert, and claystone. The oldest sediments with diagnostic fossils are within the Parhabdolithus angustus nannoplankton zone, which is late Aptian and early Albian in age (Čepek, this volume). The bottom 20 meters of sediment is unzoned because of the absence of diagnostic fossils and very poor recovery. Unit II consists of 53 meters of pelagic clay of Late Cretaceous to middle Miocene age, based on ichthyolith studies (Doyle and Riedel, this volume). Unit II is overlain by about 36 meters of clayey siliceous ooze and siliceous clay of late Miocene to early Pleistocene age (Unit I).

High sedimentation rates in the lower Albian (or upper Aptian) to Cenomanian section (Unit III) record a time when Site 464 was under a high-productivity zone. The change from accumulation of calcareous biogenic sediment to pelagic clay during the Late Cretaceous is related both to subsidence through the $\mathrm{CCD}$ and to movement of the site to a less-productive surface water mass. The change from pelagic clay to siliceous ooze and siliceous clay during the late Miocene is attributed to the movement of the site to a position under a moreproductive surface water mass formed by the mixing of subtropical and subarctic water masses. Moderately to strongly etched calcareous nannofossils in Cores 2 to 5 suggest that the sea floor was near the CCD in the Neogene.

\section{Igneous Rocks}

Igneous rocks recovered on Hess Rise are similar to igneous rocks from several other oceanic plateaus and from many oceanic islands. The petrology of these rocks not only puts some constraints on hypotheses for the origin and evolution of Hess Rise, but also adds significant data that can be used to understand the origin and evolution of other oceanic plateaus. In this section we present descriptions of the time and space relationships of igneous rocks recovered from Hess Rise, and discuss petrologic and tectonic implications for the origin of Hess Rise. Most of the information is from papers in this volume (Seifert et al.; Scott; LeeWong; and Vallier et al.), and from Vallier et al. (1980) and Windom et al. (in press). It is not our intent to present a thorough discussion of volcanic rocks on oceanic plateaus, but we emphasize that the composition of pedestal igneous rocks can give important clues to the original tectonic setting (e.g., continental fragment, island arc, oceanic island, or uplifted mid-ocean ridge) and the volcanic evolution of oceanic plateaus.

We recovered igneous rocks at three sites on Hess Rise. Tholeiitic basalt was cored on northern Hess Rise at Site 464, trachyte was recovered on southern Hess Rise at Site 465 , and alkali basalt clasts were recovered in a carbonate ooze at Site 466 on southern Hess Rise. All of the rocks we recovered are moderately to highly altered.

Sixteen centimeters of highly altered basalt was recovered beneath lower Albian or upper Aptian limestone, chert, and claystone at Site 464. Petrographic and chemical studies indicate that only iron oxide minerals and plagioclase remain as primary minerals (Seifert et al., this volume). Concentrations of major- and minorelement oxides in two samples and trace elements in three samples are given in Tables 1 and 2.

These data show wide ranges in concentrations of some elements, a result of variable original composition and low-temperature alteration. Major-element-oxide data, especially the amounts of $\mathrm{H}_{2} \mathrm{O}^{+}$and $\mathrm{K}_{2} \mathrm{O}$ and the $\mathrm{Fe}_{2} \mathrm{O}_{3} /\left(\mathrm{Fe}_{2} \mathrm{O}_{3}+\mathrm{FeO}\right)$ ratio, are most indicative of posteruptive, low-temperature alteration. For example, the average value of $\mathrm{H}_{2} \mathrm{O}^{+}$in these samples is $2.8 \%$, compared to an average of $0.2 \%$ for fresh oceanic tholeiite; the average $\mathrm{Fe}_{2} \mathrm{O}_{3} /\left(\mathrm{Fe}_{2} \mathrm{O}_{3}+\mathrm{FeO}\right)$ ratio is 0.48 , compared to 0.30 for tholeiite (Hart, 1971; Shido et al., 1971). The average concentration of $\mathrm{K}_{2} \mathrm{O}$ is $1.25 \%$, also 
SITE 464

$39^{\circ} 51.64^{\prime} \mathrm{N} 173^{\circ} 53.33^{\prime} \mathrm{E}$

$4637 \mathrm{~m}$

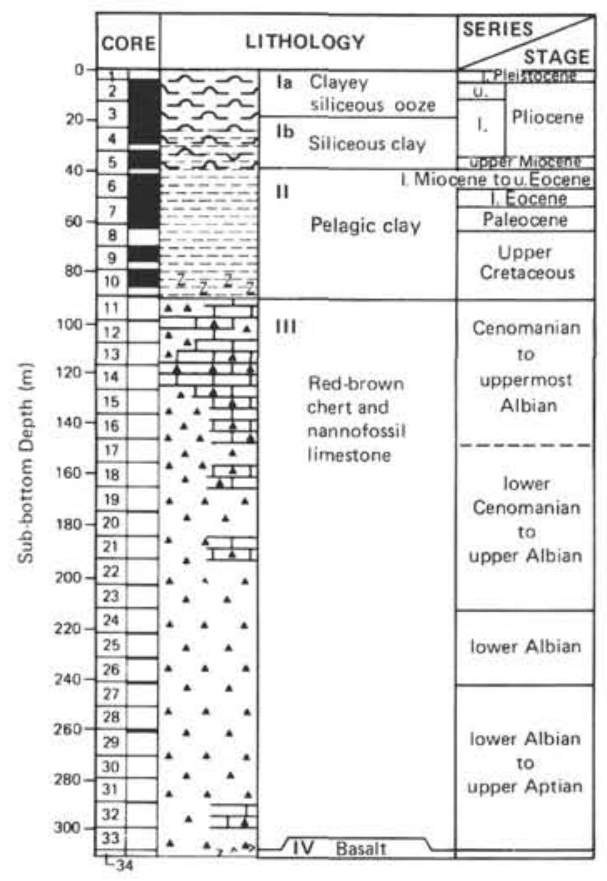

SITE 310

$36^{\circ} 52.11^{\prime} \mathrm{N} 176^{\circ} 54.09^{\prime} \mathrm{E}$

$3516 \mathrm{~m}$

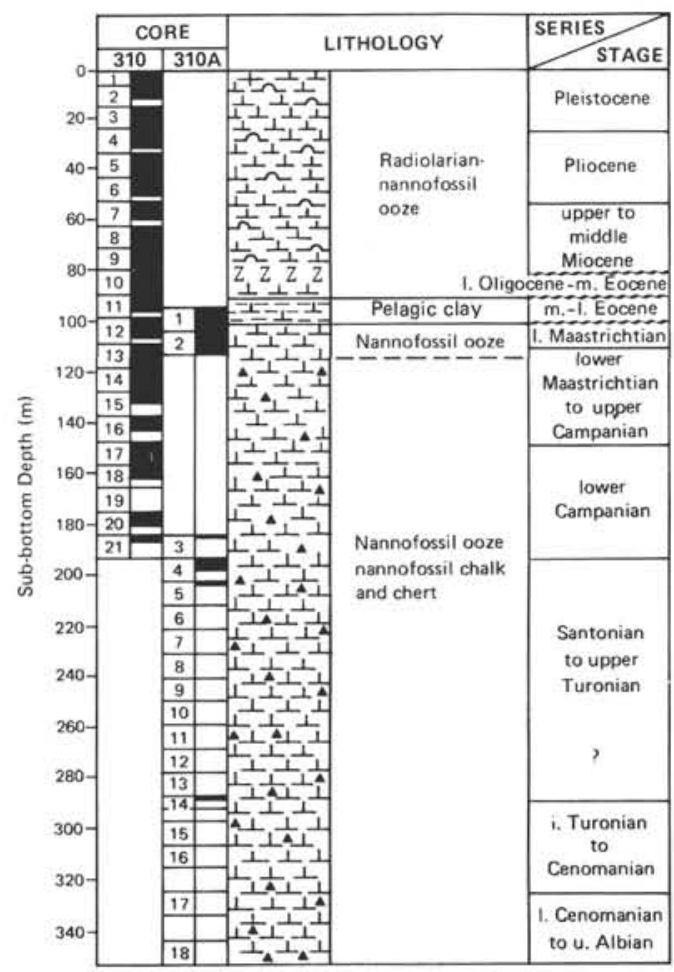

Figure 7. Generalized lithologic columns for DSDP Sites 310, 464, 465, and 466.

very high compared to an average of $0.25 \%$ for fresh oceanic tholeiite (Cann, 1971). The chemical and petrographic data, together with the high abundance of smectite, suggest that the basalt at Site 464 has been considerably altered; this alteration is similar to that described by Bass (1976), Scheidegger and Stakes (1977), and Andrews (1977).

Trace-element data (Table 2) are much more definitive in establishing the chemical affinities of the basalt from Site 464. Concentrations of the rare earth elements (REE), determined by instrumental neutron-activation analysis and normalized to chondritic meteorite abundances, are plotted in Figure 9. The REE values have a relatively flat pattern, with concentrations about 15 times the concentrations in chondrites. The REE concentrations correspond most closely to those of transitional mid-ocean-ridge basalts (Sun et al., 1979).

The chemical and petrographic data show that the basalt at Site 464 was originally a tholeiite, but they do not indicate a particular tectonic setting for eruption. The basalt could be oceanic crust erupted at a spreading center, or the basalt could have formed by off-ridge (intra-plate) volcanism. The high $\mathrm{TiO}_{2}$ and relatively low $\mathrm{Al}_{2} \mathrm{O}_{3}$ values do not support an island-arc origin, although our data do not completely preclude the possibility.

The igneous basement at Site 465 is altered trachyte (Seifert et al., this volume; Scott, this volume). About 24 meters of trachyte were recovered in Hole $465 \mathrm{~A}$ beneath limestone of late Albian to Cenomanian age. The size of the vesicles (some greater than $5 \mathrm{~mm}$ in diameter), the red iron-oxide staining in some flow units, and the current-stratified, coarse-grained sandstone between the trachyte and the Albian to Cenomanian limestone all suggest that the trachyte erupted either subaerially or in very shallow water.

Thin-section studies (Seifert et al., this volume) show three generations of feldspar as phenocrysts, laths, and microlites flow-aligned in a clay (originally glass) matrix. The compositions of the plagioclase feldspars range from 28 to $43 \%$ anorthite, and the compositions of potash feldspars range from 92 to $98 \%$ orthoclase, as determined by electron-microprobe analyses (LeeWong, this volume).

The ranges and averages of concentrations of major and minor-element oxides, trace elements, $\mathrm{H}_{2} \mathrm{O}^{+}$, $\mathrm{H}_{2} \mathrm{O}^{-}$, and $\mathrm{CO}_{2}$ in 18 samples of trachyte from Hole 465 A are given in Tables 1 and 2. Additional traceelement analyses by Scott (this volume) are not included in Table 2, but the values are similar, and most fall within the given ranges.

Windom et al. (in press) compared the compositions of the least-altered trachyte from Site 465 with those of trachytes from 14 oceanic islands and seamounts. The Hess Rise trachyte is similar to the other rocks, except that the concentration of $\mathrm{K}_{2} \mathrm{O}$ is consistently higher and that of $\mathrm{Na}_{2} \mathrm{O}$ is consistently lower in the Hess Rise trachyte. These differences may be related either to altera- 
SITE 465

$33^{\circ} 49.23^{\prime} \mathrm{N} 178^{\circ} 55.14^{\prime} \mathrm{E}$

$2161 \mathrm{~m}$

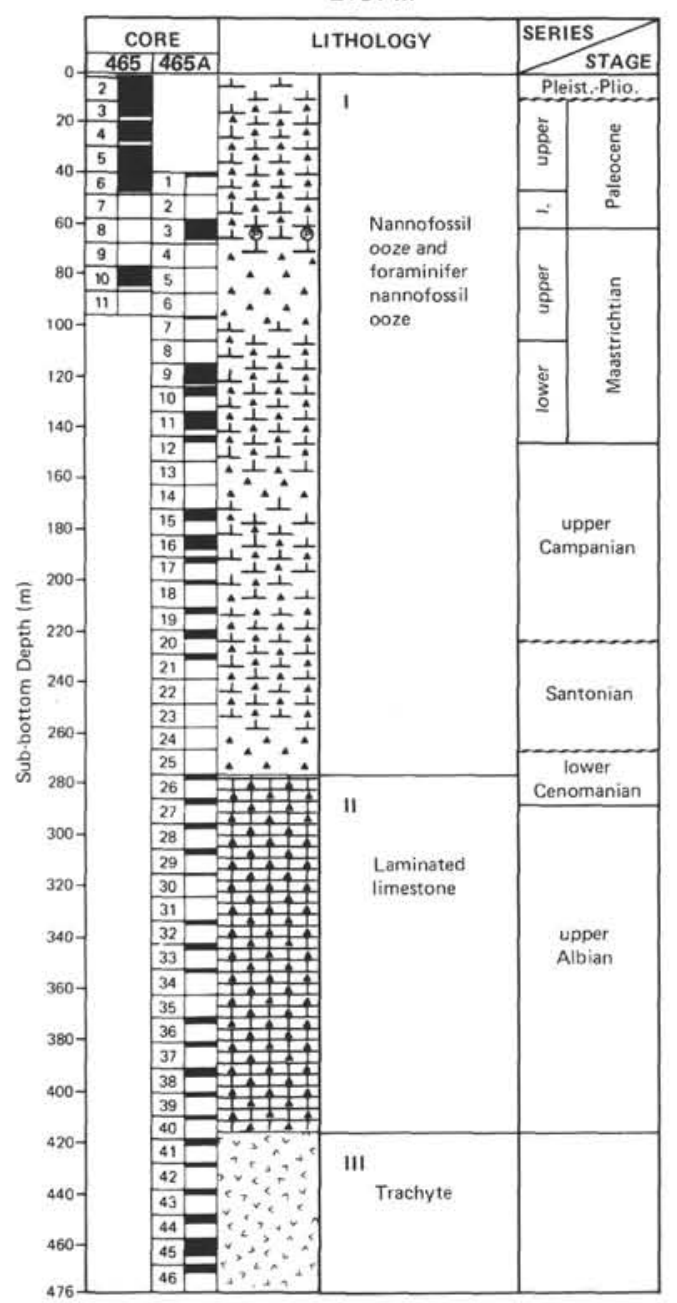

Figure 7. (Continued).

tion or to differences in compositions of the original magmas. Ranges of concentrations of trace elements, particularly rare-earth elements, are more restricted.

The REE patterns (Fig. 10) show that the light rareearth elements (LREE; e.g., La and Ce) are enriched by about 200 to 300 times relative to chondrite abundances, which is typical of alkalic rocks. The depletion of heavy rare-earth elements (HREE) relative to chondrites is also typical of alkalic rocks and probably indicates that HREE-enriched minerals such as pyroxene separated at an early stage of fractional crystallization. Windom et al. (in press) speculate that the wide range of HREE values may result from the concentration of the HREE in one or more minerals that were subsequently altered to clay minerals, thereby increasing HREE mobilities.

The trachyte at Site 465 is a differentiate of alkalibasalt magma and probably represents some of the latest volcanism on an oceanic island or seamount that crowned Hess Rise during its early evolution. We do not know that characteristics of older igneous rocks on southern Hess Rise, but we speculate, judging from data from Site 464 and from other oceanic plateaus (e.g.,

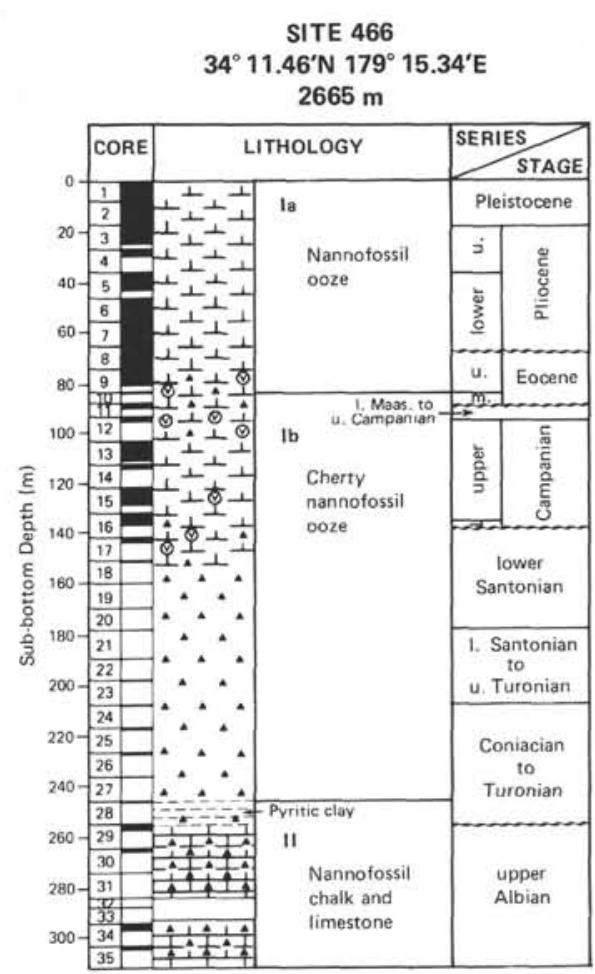

Scott, this volume), that the underlying igneous rocks are mostly tholeiitic basalt with a cap of alkali basalt and the differentiates of alkali-basalt magmas.

The original tectonic setting of Hess Rise is not known, but the setting proposed by Hilde, Isezaki, and Wageman (1976) is consistent with our data; according to these authors, Hess Rise began to form along a midocean ridge or a triple junction by the extrusion of tholeiitic basalt. Eruption of volcanic rocks may have continued along a transform fault (Windom et al., in press) where alkalic basalt and the differentiates of alkali-basalt magma were erupted as the oceanic plateau moved away from the spreading center.

Clasts of volcanic rock were recovered from nannofossil ooze of Late Cretaceous to early Eocene age in Hole 466 (Vallier et al., this volume). The clasts have both petrologic and tectonic significance for the origin and later uplift of (or volcanic activity on) Hess Rise. Thin-section studies indicate that the clasts have porphyritic intersertal and hyalopilitic textures. Phenocrysts of plagioclase, clinopyroxene, olivine, and ironoxide minerals are set in altered glassy groundmasses. 


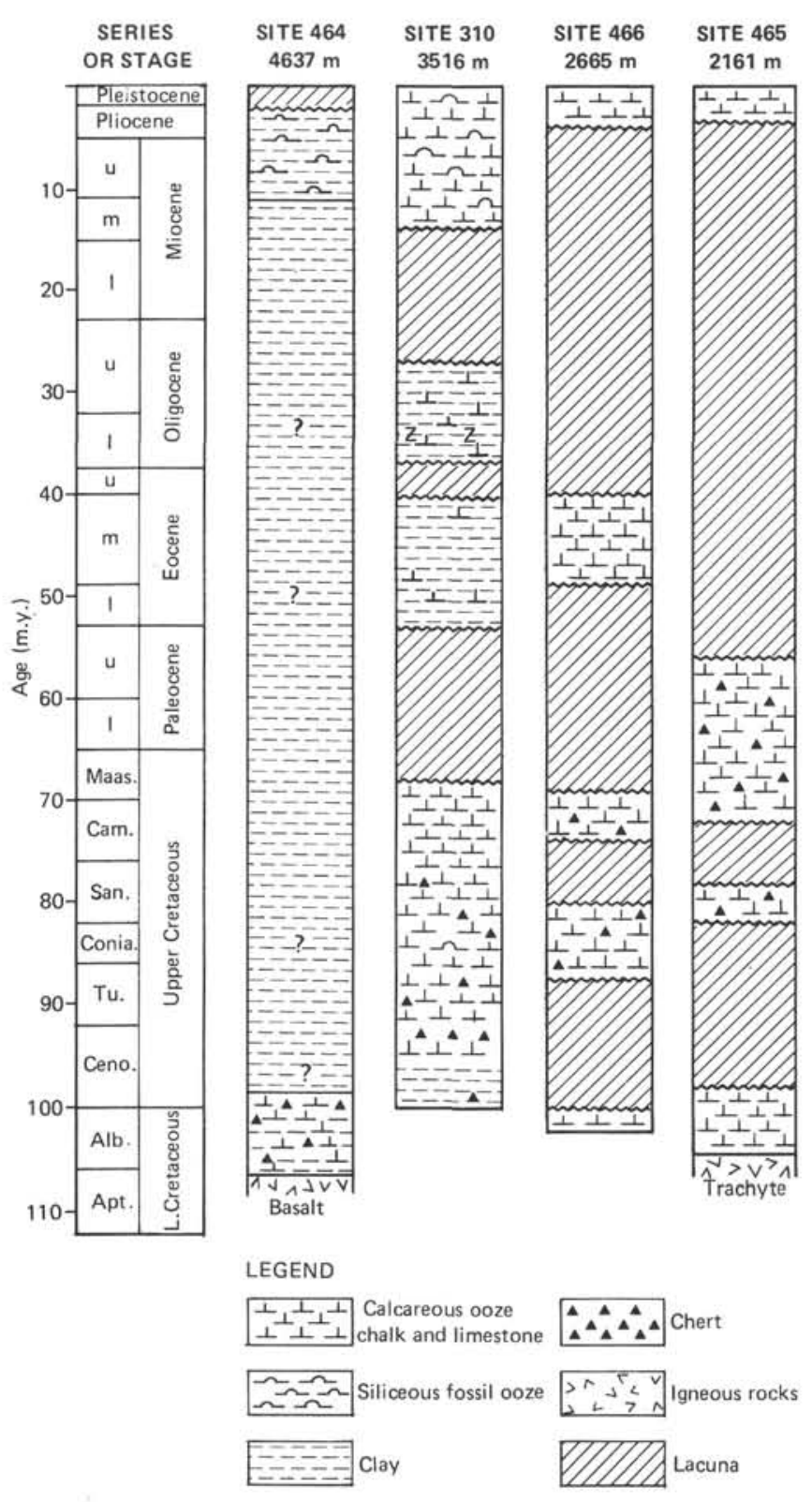

Figure 8. Generalized time-lithologic columns for DSDP Sites 310, 464,465 , and 466 .

Low-temperature alteration has led to both partial and complete replacement of primary minerals by secondary minerals that include zeolites and calcite. Primary mineral compositions of most clasts are characteristic of alkali basalt and alkali olivine basalt. Some of the extensively altered clasts probably are more-silicic differentiates of alkali-basalt magmas.

Relict clinopyroxene shows high concentrations of $\mathrm{CaO}$, and therefore high molecular percent wollastonite, which are characteristics of alkalic rocks. Plots of molecular percent wollastonite versus $\mathrm{Al}_{2} \mathrm{O}_{3}$ and $\mathrm{Na}_{2} \mathrm{O}$ show that these rocks have alkalic affinities (Vallier et al., this volume).

The volcanic-rock clasts are rounded, which suggests that they were eroded from nearby islands. We do not know the origin of the islands, but the presence of these
Table 1. Compositional ranges and averages of major- and minor-element oxides (wt.\%), as determined by X-ray fluorescence, instrumental neutron-activation analysis, and wet-chemical techniques.

\begin{tabular}{lcccc}
\hline & \multicolumn{2}{c}{ Trachyte (Site 465) } & \multicolumn{2}{c}{ Basalt (Site 464) } \\
Oxide & Range & Average & Range & Average \\
& & & & \\
$\mathrm{SiO}_{2}$ & $58.07-60.81$ & 59.66 & $45.58-46.75$ & 46.16 \\
$\mathrm{TiO}_{2}$ & $0.99-1.07$ & 1.03 & $1.72-1.75$ & 1.74 \\
$\mathrm{Al}_{2} \mathrm{O}_{3}$ & $18.40-19.08$ & 18.78 & $15.69-16.14$ & 15.92 \\
$\mathrm{Fe}_{2} \mathrm{O}_{3}$ & $2.37-3.59$ & 2.97 & $6.27-6.49$ & 6.38 \\
$\mathrm{FeO}$ & $0.14-1.00$ & 0.56 & $6.46-7.16$ & 6.81 \\
$\mathrm{MgO}$ & $0.31-2.08$ & 1.03 & $7.82-7.89$ & 7.85 \\
$\mathrm{CaO}$ & $1.94-3.40$ & 2.31 & $3.91-4.72$ & 4.32 \\
$\mathrm{Na}_{2} \mathrm{O}$ & $4.68-5.46$ & 5.12 & $3.08-3.38$ & 3.23 \\
$\mathrm{~K}_{2} \mathrm{O}$ & $2.89-6.40$ & 4.80 & $0.81-1.68$ & 1.25 \\
$\mathrm{P}_{2} \mathrm{O}_{5}$ & $0.28-0.46$ & 0.36 & $0.09-0.10$ & 0.09 \\
$\mathrm{MnO}$ & $0.015-0.060$ & 0.034 & $0.25-0.29$ & 0.27 \\
$\mathrm{H}_{2} \mathrm{O}^{+}$ & $0.60-2.68$ & 1.56 & $2.74-2.79$ & 2.76 \\
$\mathrm{H}_{2} \mathrm{O}^{-}$ & $0.64-3.98$ & 1.84 & $4.33-5.31$ & 4.82 \\
$\mathrm{CO}_{2}$ & $0.21-1.73$ & 0.47 & - & - \\
\hline
\end{tabular}

Notes: $\mathrm{Fe}_{2} \mathrm{O}_{3}$ is total iron for Site 465 analyses only. Site 465 data $(N=18)$ are for southern Hess Rise trachyte; Site 464 data $(N=2)$ are for northern Hess Rise basalt. See Seifert et al. (this volume) for a review of analytical methods.

Table 2. Trace-element ranges and averages (ppm) as determined by X-ray fluorescence and instrumental neutronactivation analysis for basalt (Site 464) and trachyte (Site 465).

\begin{tabular}{ccccc}
\hline & \multicolumn{2}{c}{ Trachyte (Site 465) } & \multicolumn{2}{c}{ Basalt (Site 464) } \\
Element & Range & Average & Range & Average \\
\cline { 2 - 4 } $\mathrm{La}$ & $7.51-89.1$ & 82.5 & $4.8-5.1$ & 5.0 \\
$\mathrm{Ce}$ & $156-187$ & 171 & $12.8-13.6$ & 13.2 \\
$\mathrm{Sm}$ & $8.9-11.7$ & 10.5 & $3.1-3.5$ & 3.2 \\
$\mathrm{Eu}$ & $2.9-3.2$ & 3.0 & $1.17-1.25$ & 1.20 \\
$\mathrm{~Tb}$ & $1.0-1.6$ & 1.3 & $0.66-0.69$ & 0.68 \\
$\mathrm{Yb}$ & $1.8-4.4$ & 2.9 & $2.37-2.96$ & 2.27 \\
$\mathrm{Lu}$ & $0.3-0.7$ & 0.5 & $0.32-0.42$ & 0.36 \\
$\mathrm{Rb}$ & $15.3-66.5$ & 33.6 & & \\
$\mathrm{Ba}$ & $596-688$ & 645 & & \\
$\mathrm{Th}$ & $13.9-18.9$ & 16.9 & $3.16-3.17$ & 3.16 \\
$\mathrm{Ta}$ & $8.4-11.1$ & 9.6 & $0.26-0.28$ & 0.27 \\
$\mathrm{Zr}$ & $474-829$ & 715 & $111-112$ & 111 \\
$\mathrm{Sr}$ & $251-397$ & 311 & $158-178$ & 167 \\
$\mathrm{Co}$ & $8.5-22.6$ & 16.2 & $38.6-50.3$ & 45.3 \\
$\mathrm{Sc}$ & $2.1-3.2$ & 2.7 & $55.0-55.8$ & 55.3 \\
\hline
\end{tabular}

Note: For trachyte, $N=18$; for basalt, $N=3$.

clasts certainly records an important event in the evolution of Hess Rise. The islands may have formed by uplift of older mid-Cretaceous igneous crust during Late Cretaceous(?) and(or) early Tertiary tectonism. Alternatively, the islands being eroded during that time may have been built by volcanism. There is some inconclusive evidence that volcanic activity on or near Hess Rise occurred in the Late Cretaceous to early Tertiary (Vallier and Jefferson, this volume), but apparently it was not extensive.

\section{Organic-Carbon-Rich Limestone Facies}

The mid-Cretaceous limestones that contain abundant organic matter, recovered from Sites 465 and 466, 


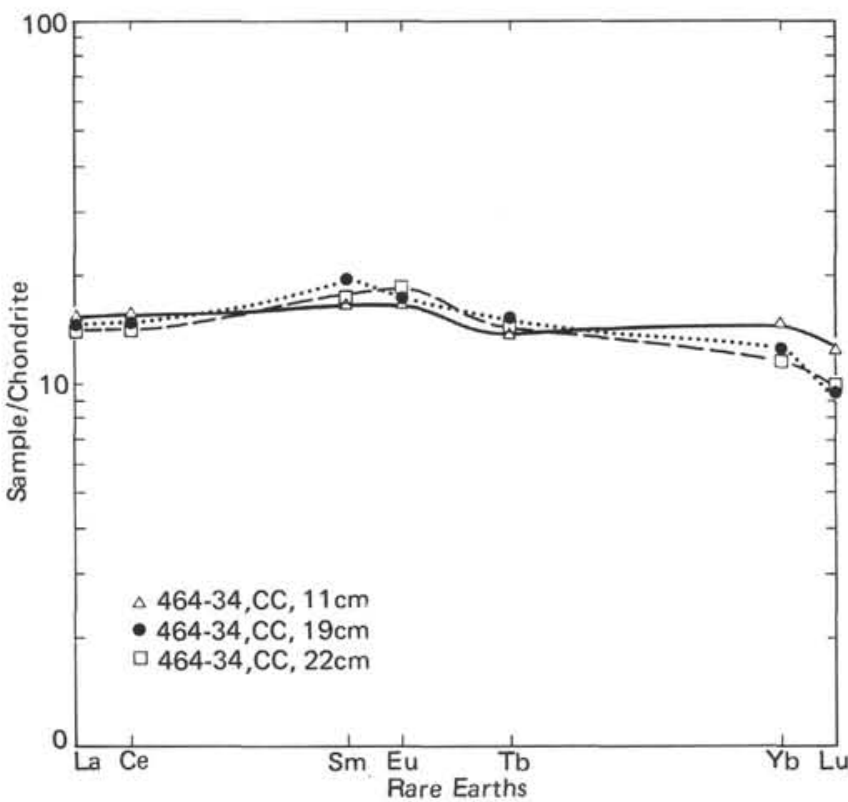

Figure 9. Distribution of rare-earth elements, normalized to chondrite abundances, in basalt samples from Hole 464, northern Hess Rise (Seifert et al., this volume).

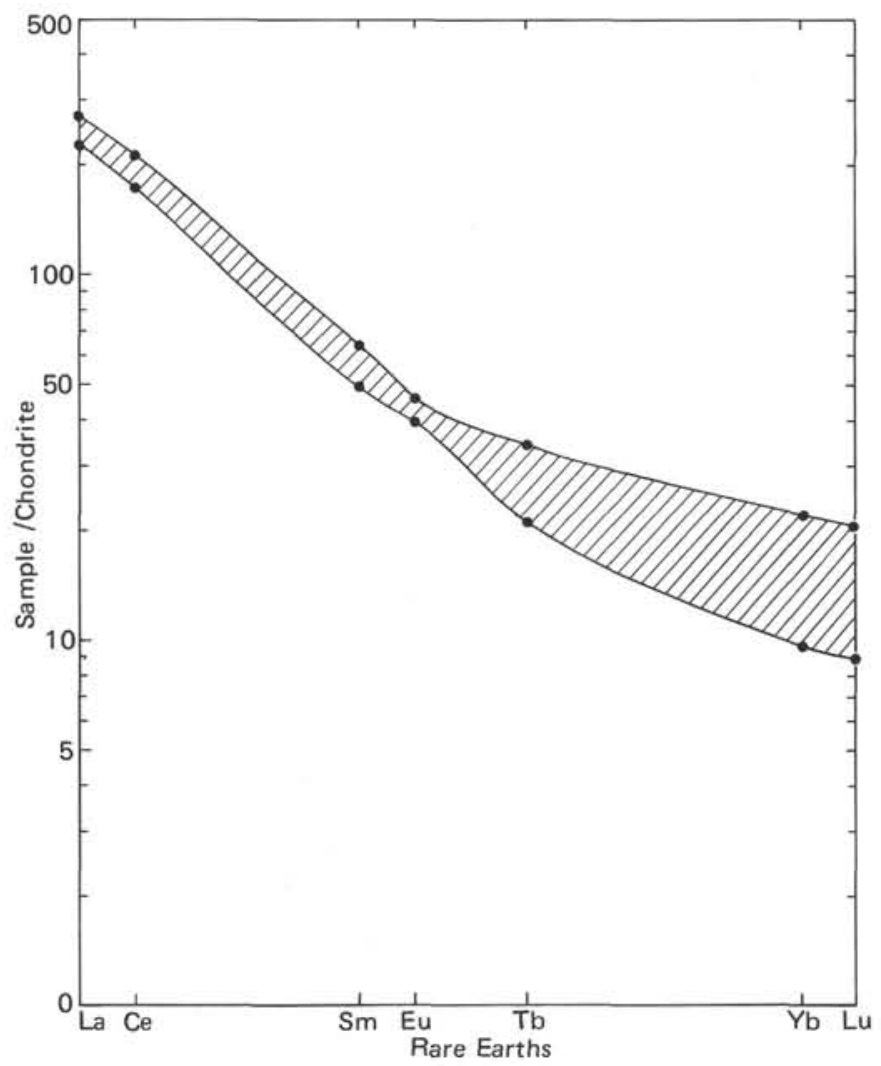

Figure 10. Distribution of rare-earth elements, normalized to chondrite abundances, in samples of trachyte from Hole $465 \mathrm{~A}$, southern Hess Rise (Seifert et al., this volume).

on southern Hess Rise, were studied by Dean et al., Mélières et al., Simoneit, and Timofeev and Bobolyubova (all this volume). The oldest sedimentary lithologic unit at Site 465 (Unit II, upper Albian to lower Cenomanian, deposited about 98 to 103 m.y. ago) consists of 136 meters of laminated, olive-gray limestone, containing up to $8.6 \%$ organic carbon. The lateral equivalent of this unit at Site 466 consists of about 66 meters of olive chalk and limestone of late Albian age (100-101 m.y.) containing up to $8.1 \%$ organic carbon.

Rocks of mid-Cretaceous age containing more than $2 \%$ organic carbon have been reported from several other DSDP sites on elevated plateaus and seamounts in the central Pacific. Two samples of volcanic siltstone containing 2.8 and $2.3 \%$ organic carbon were reported from Site 171 on Horizon Guyot (Winterer, Ewing, et al., 1973). One sample of early Aptian to Barremian (>115 m.y.) olive-gray silicified clayey porcellanite from Hole 305 on Shatsky Rise contained $9.3 \%$ organic carbon (Larson, Moberly, et al., 1975). A small fragment of early Cenomanian to late Albian age (92-97 m.y.) in the core catcher of Core 17, Hole 310A, central Hess Rise, was described as black carbonaceous pelagic shale (Larson, Moberly, et al., 1975). No organiccarbon analyses of this fragment were made, but it had a bituminous odor and burned when heated. One sample of a calcareous bed within pre-Aptian ( $>120$ m.y.) volcanic sandstone in Hole 317A, on Manihiki Plateau, was reported to contain $28.7 \%$ organic carbon (Schlanger, Jackson, et al., 1976). Three thin beds within a lower Aptian (about 113 m.y.) dark-colored pelagiclimestone sequence in Hole 463, in the Mid-Pacific Mountains, contain as much as $7.5 \%$ organic carbon (Dean et al. and Mélières et al., both this volume; Thiede et al., in press).

Three basic models have been proposed to describe conditions under which marine sediments rich in organic matter might accumulate in a deep-sea environment. The first model is that of a stratified deep basin with anoxic bottom waters (e.g., Ryan and Cita, 1977; Thiede and van Andel, 1977; Arthur and Schlanger, 1979; Demaison and Moore, 1980; among others). The most commonly used modern example of this type of environment is the present Black Sea (Degens and Ross, 1974). Well-documented ancient examples of sections with reduced sediment include the Pleistocene Mediterranean Sea (Ryan, 1972; Nesteroff, 1973), the Lower Jurassic of Great Britain (Morris, 1979), and the midCretaceous (Mowry Shale) of the western interior of North America (Nixon, 1973; Byers and Larson, 1979).

The second model actually consists of a group of similar models, all involving a mid-water oxygen minimum that impinges on a continental margin, an oceanic plateau, or a seamount (Schlanger and Jenkyns, 1976; Fischer and Arthur, 1977; Thiede and van Andel, 1977; Arthur and Schlanger, 1979). Oxygen minima are common in coastal regions where high surface-water productivity, usually caused by upwelling, results in high biological oxygen demand and depletion of oxygen at mid-water $(\sim 200$ to $\sim 1000 \mathrm{~m})$ depths. The sediment in regions of an oxygen minimum often contains more than $2 \%$ organic carbon. Probably the best known coastal environment of this type is the high-productivity upwelling system associated with the Benguela Current off Namibia, Southwest Africa (Calvert and Price, 1971; Brongersma-Sanders, 1957, 1966). Similar condi- 
tions exist off the coasts of Peru, Chile, northwest Africa, western Australia, California, western Mexico, India, and Arabia. The oxygen minimum in the eastcentral Pacific Ocean extends westward for a considerable distance from the continental margins of North and South America. Where mid-ocean volcanic plateaus and seamounts intersect this minimum, organic matter may accumulate in sediments in much the same way it does where the oxygen minimum impinges on a continental margin. An intensified and(or) expanded oxygen minimum in the past could have resulted in greater accumulation of organic-carbon-rich sediments-both in total amount and in lateral extent, and may have resulted in low-oxygen conditions in bottom waters over large parts of the world ocean (Schlanger and Jenkyns, 1976; Fischer and Arthur, 1977; Thiede and van Andel, 1977; Arthur and Schlanger, 1979).

A third model for the accumulation of organic matter involves depletion of oxvgen in the sediments in response to a high rate of supply of organic matter (Gardner et al., 1978). According to this model, the zero-oxygen isopleth may be at or above the sediment/water interface, or within the sediments, depending upon the relative rates of supply of organic matter, supply of oxygen, and depletion of oxygen by biological oxygen demand within the sediment and overlying waters (Gardner et al., 1978; Demaison and Moore, 1980). Anoxic conditions in the sediments and possibly in the water column for some distance above the sediment/water interface are caused by oxygen consumption within the sediments, and are not necessarily related to reduction of oxygen in the overlying waters, although restricted circulation of bottom waters containing little or no oxygen may be required for total oxygen depletion and the accumulation of hydrogen sulfide. Variations in the rate of supply of organic matter would result in variations in the positions of the zero-oxygen isopleth and could result in cyclic interbeds of oxic and anoxic sediments such as those commonly observed in mid-Cretaceous strata of the Atlantic Ocean (Dean, Gardner, et al., 1978; Dean, Barron, et al., 1981; Gardner et al., 1978; Arthur et al., 1980).

The following observations place constraints on which model or models of accumulation of organic-carbon-rich sediments might be used to explain the genesis of the mid-Cretaceous strata recovered at the seven Pacific DSDP sites described in references cited above.

1) Except for the sites on southern Hess Rise (Sites 465 and 466) all of the reported organic-carbon-rich rocks in the Pacific have a very restricted stratigraphic range, and at four of the seven sites the organic-carbonrich facies is defined by only one or two samples.

2) All Pacific occurrences of organic-carbon-rich rocks are from oceanic plateaus at intermediate water depths; strata of equivalent age in adjacent deep basins do not contain high concentrations of organic matter.

3) The organic-carbon-rich rocks in the Pacific are all mid-Cretaceous in age, but they are not synchronous, and they range from as early as 84 m.y. on Horizon Guyot to more than 120 m.y. on Manihiki Plateau.
4) All mid-Cretaceous organic-carbon-rich strata in the Pacific are associated with volcanic material.

5) All sites underlain by organic-carbon-rich strata were in relatively shallow water and were south of or very near the Equator during the mid-Cretaceous.

6) Organic-carbon-rich strata usually occur interbedded with organic-carbon-poor strata on a scale of tens of centimeters. The organic-carbon-rich and -poor interbeds in the mid-Cretaceous of the Atlantic and of Tethys are usually manifested as cyclic variations in lithology and(or) color (Dean et al., 1978, 1981; Arthur et al., 1980; Weissert et al., 1979), and it is usually easy to predict which layers are likely to contain high concentrations of organic carbon. The organic carbon-rich layers are not as obvious, however, in the mid-Cretaceous strata of the Pacific. Olive-gray, laminated, foraminifer- and radiolarian-rich limestone at Site 465 includes 136 meters of stratigraphic section that spans about $5 \mathrm{~m}$.y. from the late Albian to early Cenomanian. Similar-appearing samples of this limestone may contain less than $1 \%$ to more than $3 \%$ organic carbon. Cyclic interbeds of white, light-gray, dark-gray, black, and green limestones with highly variable amounts of volcanic ash and silica constitute 45 meters of stratigraphic section at Site 463. Many of the beds are laminated and dark-colored and appear to be rich in organic matter, but only three intervals contain concentrations of organic carbon greater than $2 \%$ (Dean et al. and Mélières et al., this volume; Thiede et al., in press). These organic-carbon-rich intervals occur within about 6 meters of section that spans only about $10^{5}$ years.

7) The source of the organic matter in the mid-Cretaceous rocks in the Pacific appears to be mostly lipidrich, autochthonous, marine organic matter. Dean et al. (this volume) concluded from pyrolysis-assay results that most of the organic matter in the mid-Cretaceous limestones from Sites 465 and 466 on southern Hess Rise and Site 463 in the Mid-Pacific Mountains is composed of lipid-rich kerogen derived from aquatic marine organisms, and that contributions from terrigenous organic matter are minor. Petrographic studies of organic matter from Sites 463,465 , and 466 by Timofeev and Bogolyubova (this volume) showed that most of the organic matter is sapropelic, and that only the lower few cores in Hole $465 \mathrm{~A}$ contain appreciable amounts of humic organic matter. Analyses of one sample from Hole 466 on Hess Rise by Simoneit (this volume) showed that the lipids are primarily of autochthonous marine origin.

Data on the carbon-isotope composition of the organic matter are somewhat equivocal (Dean et al., this volume). The organic carbon is isotopically light $\left(\delta^{13} \mathrm{C}\right.$ $=-24$ to $-29 \%$ ) relative to modern marine organic carbon $\left(\delta^{13} \mathrm{C}=-9\right.$ to $\left.-30 \%\right)$, and lightest carbon is most lipid-rich. The $\delta^{13} \mathrm{C}$ values are within the range of $\delta^{13} \mathrm{C}$ values for terrestrial organic carbon, Cretaceous petroleum, and organic carbon from Cretaceous strata in other ocean basins where the organic matter, based on other geochemical evidence, is judged to be of marine, terrestrial, and(or) mixed origin. The isotopic evidence also suggests that Cretaceous petroleum and the 
organic matter in mid-Cretaceous organic-carbon-rich strata were derived from terrigenous organic matter, which contradicts most other geochemical evidence. A more likely conclusion is that we do not fully understand the relations between carbon-isotope composition and the biogeochemistry of carbon.

That the organic-carbon-rich mid-Cretaceous strata in the Pacific only occur on oceanic plateaus and seamounts, that they are not synchronous, and that most occur over very short stratigraphic (and time) intervals cannot be explained by complete deoxygenation of bottom waters. That most of the organic-carbon-rich strata are not synchronous, and that they formed over a time of as much as 40 m.y. cannot easily be reconciled by the expanded oxygen-minimum model proposed by Schlanger and Jenkyns (1976) and Jenkyns (1980). Yet, all of these strata were deposited during a time (the midCretaceous) when sediments rich in organic matter were accumulating at many places, especially in the Atlantic Ocean. During this time, oceanic surface- and bottomwater temperatures also were high (Douglas and Savin, 1975; Fischer and Arthur, 1977). Increased water temperatures would have had two main effects: first, thermohaline deep-water circulation, driven today by the sinking of cold, oxygen-rich surface waters in high latitudes, would have been more sluggish; and second, the warmer water would contain lower concentrations of dissolved oxygen. Bottom-water circulation was sufficient to supply some oxygen to maintain oxidizing conditions in the deep basins of the Pacific, but slow enough to permit depletion of dissolved oxygen in areas of high productivity of organic matter.

All occurrences of organic-carbon-rich rocks in the Pacific, except those on southern Hess Rise (Sites 465 and 466), appear to have been caused by short-lived events of oxygen depletion somehow associated with volcanic activity. The organic-carbon-rich strata at the southern Hess Rise sites appear to have been deposited in oxygen deficient environments that lasted at least several millions of years and resulted in the accumulation of thick sequences of pelagic strata containing abundant organic matter. The Hess Rise sites probably were under an equatorial zone of high surface-water productivity when these strata accumulated. Most of the Hess Rise organic-carbon-rich strata are laminated, but the cross-stratification and good sorting of these rocks (Site 465 report, this volume) suggest that they were deposited in relatively shallow water. The benthic foraminifers in the Site 465 strata suggest that they were deposited in an upper-bathyal environment (Boersma, this volume). The association of thin beds of volcanic ash with these strata and the abundance of smectite in the non-carbonate fractions (Vallier and Jefferson, this volume) indicate that volcanic activity was still going on after the main constructive phases of volcanism on Hess Rise ceased. We conclude that the organic-carbon-rich strata on southern Hess Rise were deposited on a part of the rise above the CCD and within an oxygen-minimum zone, as the rise crossed under a highly productive equatorial divergence (the equatorial crossing model of Thiede et al., in press).
The short-lived anoxic events associated with volcanic activity at Pacific localities other than Hess Rise were the results of local tectonic and oceanographic factors (the organo-volcanic spike model of Thiede et al., in press). Volcanic islands and near-surface rises that must have existed in the central Pacific during the midCretaceous interrupted the flow of surface currents. Fertile surface waters near islands and shoals may have been made more productive by current-induced upwelling and land-derived nutrients. Any oxygen-deficient environments that may have resulted from increased productivity probably developed only locally and had a short duration. Also, these environments would have formed at different places at different times, but all within the general period of highly productive and warm surface waters during the mid-Cretaceous.

\section{Pelagic Carbonate Facies}

Sections of relatively pure nannofossil or foraminifer-nannofossil ooze and chalk were recovered at Sites 310,465 , and 466. Calcareous ooze at Site 310, on the central part of Hess Rise, contains larger admixtures of siliceous-microfossil debris and clay than at either of the sites on southern Hess Rise. This difference is probably due to concentration of siliceous debris and clay left after dissolution of carbonate in ooze from Site 310, because this site, at a water depth of 3516 meters, is close to the present $\mathrm{CCD}$, and has always been closer to the CCD than the southern Hess Rise sites, which are presently at water depths of 2161 meters (Site 465) and 2665 meters (Site 466$)$. The thin $(10 \mathrm{~m})$ pelagic-clay unit at 90 to 100 meters sub-bottom at Site 310 spans at least the middle Eocene, and may extend back into at least part of the Late Cretaceous. The pelagic clay unit between carbonate units indicates that the CCD fluctuated at this part of Hess Rise.

The entire sedimentary sections at Sites 465 and 466 on southern Hess Rise are records of pelagic carbonate sedimentation. Unfortunately, the sections contain several major lacunas (Fig. 8); poor recovery because of abundant chert makes the records even less complete. In spite of poor recovery, the progressive diagenetic change from ooze to chalk to limestone within the pelagic-carbonate facies is recognizable at all three sites $(310,465$, and 466$)$. Progressive diagenesis during burial of the carbonate facies also is shown by decreasing concentrations of strontium with increasing depth in samples from Holes 465A and 466 (Dean, this volume). Matter et al. (1975) observed a similar decrease in strontium with depth in pelagic carbonates on Shatsky Rise, which they attributed to an increase with depth in low$\mathrm{Sr}$ overgrowths on microfossils.

The best record of the pelagic-carbonate facies occurs at Site 465 , where the top of the sedimentary section contains about 270 meters of structureless, remarkably uniform nannofossil ooze of late Coniacian to late Paleocene age, and about 2 meters of foraminifer-nannofossil ooze of Plio-Pleistocene age.

Neogene pelagic calcareous facies are best represented at Sites 310 and 466 . A well-developed (about 60 $\mathrm{m}$ thick) Pleistocene to lower Pliocene sequence occurs 
at both sites, and a condensed (about $20 \mathrm{~m}$ thick) lowermost Pliocene and upper and middle Miocene section at Site 310 . At both sites, a marked change in sedimentary regime occurred about 4.2 m.y. ago, from slow or nondeposition in the early Neogene to normal pelagic sedimentation through the rest of the Neogene and Pleistocene (Vincent, this volume). Fluctuations in carbonate content within the Neogene are concordant with those in Neogene sequences from the equatorial Pacific. Vincent (this volume) relates carbonate-dissolution spikes within these Neogene sequences to global changes in the chemistry of the ocean linked to regression-cooling events.

Rea and Harrsch (this volume) show that massaccumulation rates of eolian material in the pelagiccarbonate facies on Hess Rise are high for carbonate oozes of late Cenozoic age, with a maximum about 4 to $5 \mathrm{~m}$.y. ago, probably caused by increased volcanic activity. Eolian mass-accumulation rates in carbonate facies of Maastrichtian to Campanian age on Hess Rise are very low relative to mass-accumulation rates of eolian material in pelagic carbonates of the same age on oceanic plateaus farther south. Many DSDP sites, presently located in the central Pacific, have records of increased Late Cretaceous volcanic activity (e.g., Sites $165,169,170,171,198,315,316,462$, and 463 ), which suggests that many of the oceanic plateaus were created during this period of volcanic activity. Hess Rise apparently did not receive much of this Upper Cretaceous volcanic material. However, the Albian organic-carbonrich limestone at Sites 465 and 466 contains abundant volcanic material (Rea and Harrsch; Vallier and Jefferson, both this volume), which is to be expected, because the basement or volcanic pedestal rocks of southern Hess Rise probably were being eroded at the same time the carbonate was being deposited.

\section{Pelagic-Clay Facies}

Pelagic clays were recovered from northern Hess Rise (Site 464) and the central platform (Site 310). At Site 464, upper Miocene and Pliocene greenish-gray clay grades downward into 53 meters of yellowish-brown to dark-brown clay. Sediments in the brown-colored clay of Site 464 contain no siliceous or calcareous microfossils, but have been tentatively dated by ichthyoliths (Doyle and Riedel, this volume) as Late Cretaceous to early Miocene. Pelagic clay containing early and middle Eocene calcareous nannofossils comprises a section about 10 meters thick in Hole 310 (Larson, Moberly, et al., 1975).

Linear sedimentation rates of these units range from about $2 \mathrm{~m} / \mathrm{m}$.y. for the nannofossil-bearing pelagic clay of Site 310 , to an average of $0.4 \mathrm{~m} / \mathrm{m}$.y. for clay at Site 464. The section at Site 464 , however, likely has several diastems that cannot be recognized in the recovered core material. Samples of pelagic clay from Site 464 have an average porosity of about $80 \%$, which, when converted to dry-bulk density $\left(0.52 \mathrm{~g} / \mathrm{cm}^{3}\right)$ and combined with the overall linear sedimentation rate, gives a mass-accumulation rate of $0.01 \mathrm{~g} \cdot \mathrm{cm}^{-2} \cdot 10^{-3} \mathrm{yr}^{-1}$, which is low even for deep-sea pelagic clay.

Illite and chlorite are the dominant clay minerals in the upper siliceous-clay unit and in the underlying brown-clay unit into Core 6, Hole 464 . Core 6 records a change from the illite- and chlorite-dominated Miocene clay to a smectite-dominated Paleocene clay. Older, Upper Cretaceous sediments show a slight increase in the amount of illite.

The authigenic fraction (oxides, hydroxides, opal, and zeolites) of the pelagic clay in Hole 464 is 30 to $35 \%$ of most samples, except in the Paleocene sediments, where it reaches a maximum of about $50 \%$ (Rea and Harrsch, this volume). Maximum amounts of authigenic material occur in the same places as the maximum amounts of smectite (Fig. 11). Fish remains, plagioclase, and volcanic glass are minor but constant compo-

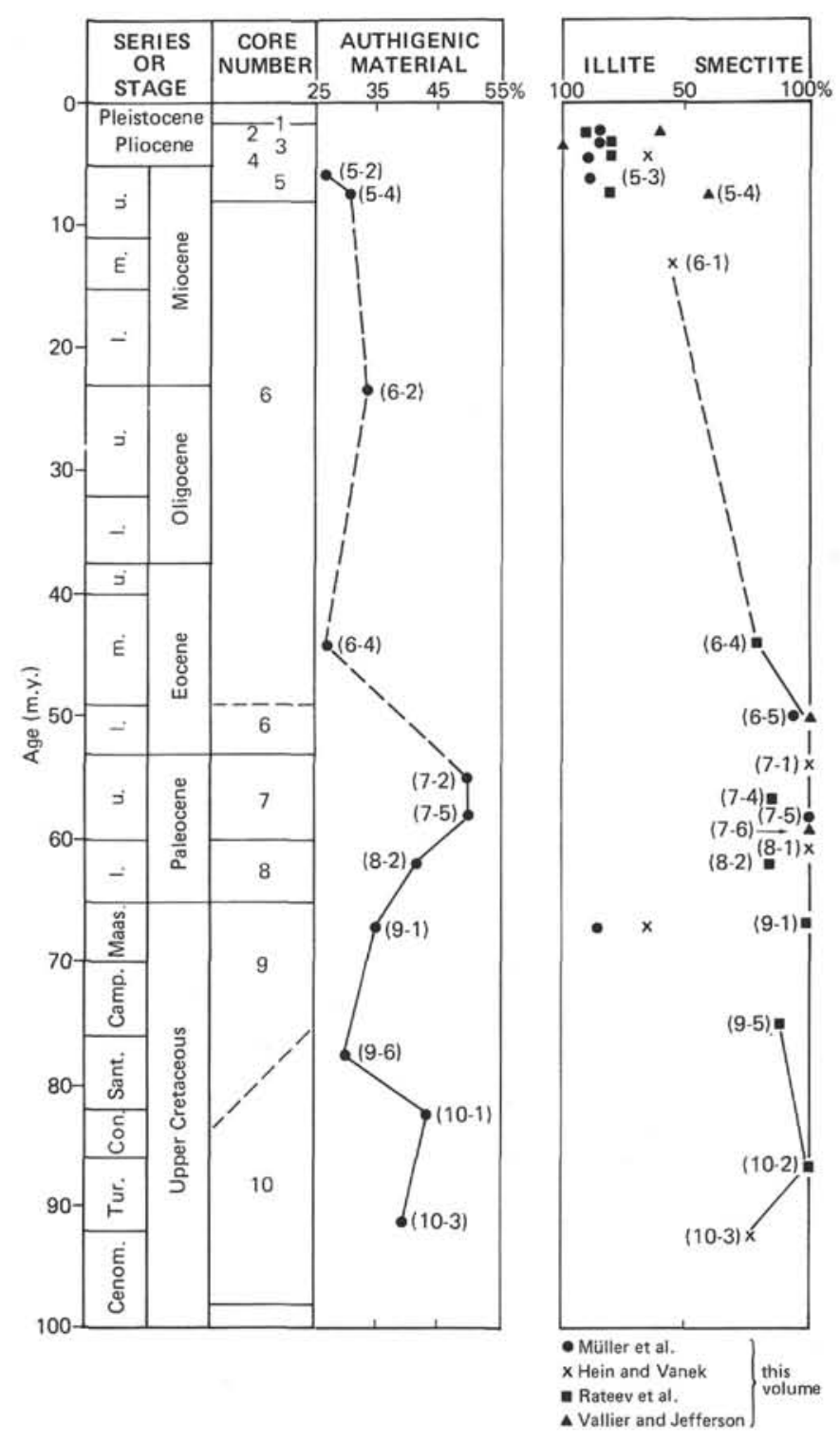

Figure 11. Approximate age, authigenic-material content, and illite/ smectite ratio of clay minerals in samples from Hole 464. Ages of Cores 6 to 10 are from Doyle and Riedel (this volume). Percentages of authigenic material are from Rea and Harrsch (this volume). Clay mineral data are from Müller et al., Hein and Vanek, Rateev et al., and Vallier and Jefferson, all in this volume. Samples from Cores 5 through 10 are identified by core and section numbers. 
nents of the pelagic clay facies in Hole 464 (Timofeev and Koporulin, this volume).

Major-, minor-, and trace-element chemistries show the heterogeneity of the pelagic-clay composition (Dean, this volume; Varentsov, this volume). Notable increases down-hole from the siliceous clay to the brown clay occur in the concentrations of iron, potassium, titanium, manganese, cobalt, chromium, copper, lanthanum, molybdenum, yttrium, and zinc. Other elements also show irregularities in concentration. The pelagic brown clay contains especially high concentrations of iron and manganese in hydrated oxides of iron and manganese, which are effective scavengers of trace metals, particularly nickel, copper, cobalt, and zinc, and to a lesser extent chromium, molybdenum, barium, and lead. As a result of this scavenging, the pelagic brown clay contains high concentrations of many trace elements, particularly in the basal, zeolite-rich part of the unit (Dean, this volume). The siliceous clay of Unit I, Site 464, is enriched in barium by a factor of about 10 relative to the underlying pelagic-clay unit (fig. 4 , table 5 of Dean, this volume). This is further evidence of concentration of barium by organisms in pelagic marine sediments, suggested by many investigators (see Dean and Schreiber, 1978, and Church, 1979, for reviews of this problem).

Because Site 464 is about 1500 meters above the surrounding deep ocean floor, and on the crest of a low rise, it is unlikely that much of the pelagic clay was deposited by bottom or nepheloid-layer processes that occur in the abyssal Pacific. We conclude that most of the material is probably eolian, although local reworking certainly is possible. The two main sources of eolian material are dry continental surfaces and volcanoes. The mineralogy and amount of authigenic material in the clays on northern Hess Rise (Fig. 11) suggest that both of these sources contributed eolian materials. The illite domination of Pliocene to Miocene siliceous clay and brown pelagic clay implies that these sediments were derived from an Asiatic continental source. Cores of approximately early Miocene to middle Eocene age contain a mixture of smectite and illite, suggesting a mixed continental and volcanic source, and lower Eocene and Paleocene pelagic clay is almost entirely smectite, indicating a significant volcanic input (Hein and Vanek, this volume). Upper Cretaceous brown clay is dominated by smectite, but contains some illite, which suggests a mixed but mostly volcanic source.

During the Paleocene, Site 464 would have been at about $25^{\circ} \mathrm{N}$ (using the plate-rotation scheme of Lancelot, 1978), near the northern edge of the northeast tradewind zone as presently defined. The site would have been far from a land source to the east $(8000-9000 \mathrm{~km}$; Firstbrook et al., 1979), but fairly close to the actively erupting volcanoes that now are the Emperor Seamounts (Hein and Vanek, this volume; Dalrymple et al., 1980). The high-smectite, high-authigenic-mineral Paleocene interval (Fig. 11) likely records this period of activity along the Emperor Seamount chain.

Continued northward migration would have placed Site 464 under the prevailing westerly winds sometime during the Eocene, thereby making more continent-de- rived eolian material available at the site. The increasing amount of illite in the younger sediments at Site 464 records the increasing importance of continent-derived materials, the increasing aridity of Neogene climates, and perhaps the increasing vigor of the late Cenozoic winds.

\section{Surface Sediments}

Surface and near-surface lithologies and the surface sediment distribution on Hess Rise (Figs. 12 and 13) were interpreted from brief descriptions of piston cores provided by Lamont-Doherty Geological Observatory and Scripps Institution of Oceanography, and from the DSDP drilling results. We have identified three major facies of surface sediment-pelagic clay, marl, and calcareous ooze-based on estimates of the amount of carbonate. One minor facies has abundant siliceous microfossils and variable amounts of calcareous fossils and clay.

The calcareous ooze generally is found only at water depths shallower than about 3000 meters, and pelagic clay is the dominant sediment below about 4000 meters. Sediment that lies between depths of about 3000 and 4000 meters is mostly marl $\left(30-60 \% \mathrm{CaCO}_{3}\right)$. The present CCD on Hess Rise lies below 4000 meters, which is in agreement with the 4400-meter depth estimated by Berger et al. (1976). Using these carbonate-depth relationships to define the facies boundaries, we constructed the lithofacies map (Fig. 13). The minor siliceous facies mainly occurs on northern Hess Rise (north of about $37^{\circ} \mathrm{N}$ ) and is related to surface-water productivity near the boundary between the central and subarctic water masses.

\section{SEISMIC STRATIGRAPHY}

A major contribution of the Deep Sea Drilling Project has been drilling results that can be related to seismic or acoustic stratigraphy. The early cruises were in large part directed toward determining the ages and characteristics of acoustic units and the boundaries between them. The four holes drilled on Hess Rise greatly aid our interpretations of the seismic stratigraphy. This section is written to show some of the major characteristics of the seismic stratigraphy on Hess Rise and to relate the seismic units to drilling results.

Seismic-reflection records discussed in this section (Fig. 2) were collected with single-channel air-gun seismic systems on Lamont-Doherty Geological Observatory cruises Vema 20 (1964), Conrad 10 (1966), and Vema 32 (1975), and on Scripps Institution of Oceanography cruise Aries 7 (1971) and Glomar Challenger Legs 32 (1973) and 62 (1978). Air-gun firing rates were at 10 -second intervals, and recording sweep rates were 10 seconds. Glomar Challenger Leg 62 utilized both 10and 5-second sweep rates.

Interpretations of seismic records in other parts of the world ocean have guided our interpretations to some extent. For example, pelagic ooze and pelagic clay generally are acoustically transparent. Volcanic ash layers, turbidites, some unconformities, clathrate horizons, and diagenetic changes such as the transition from mud 

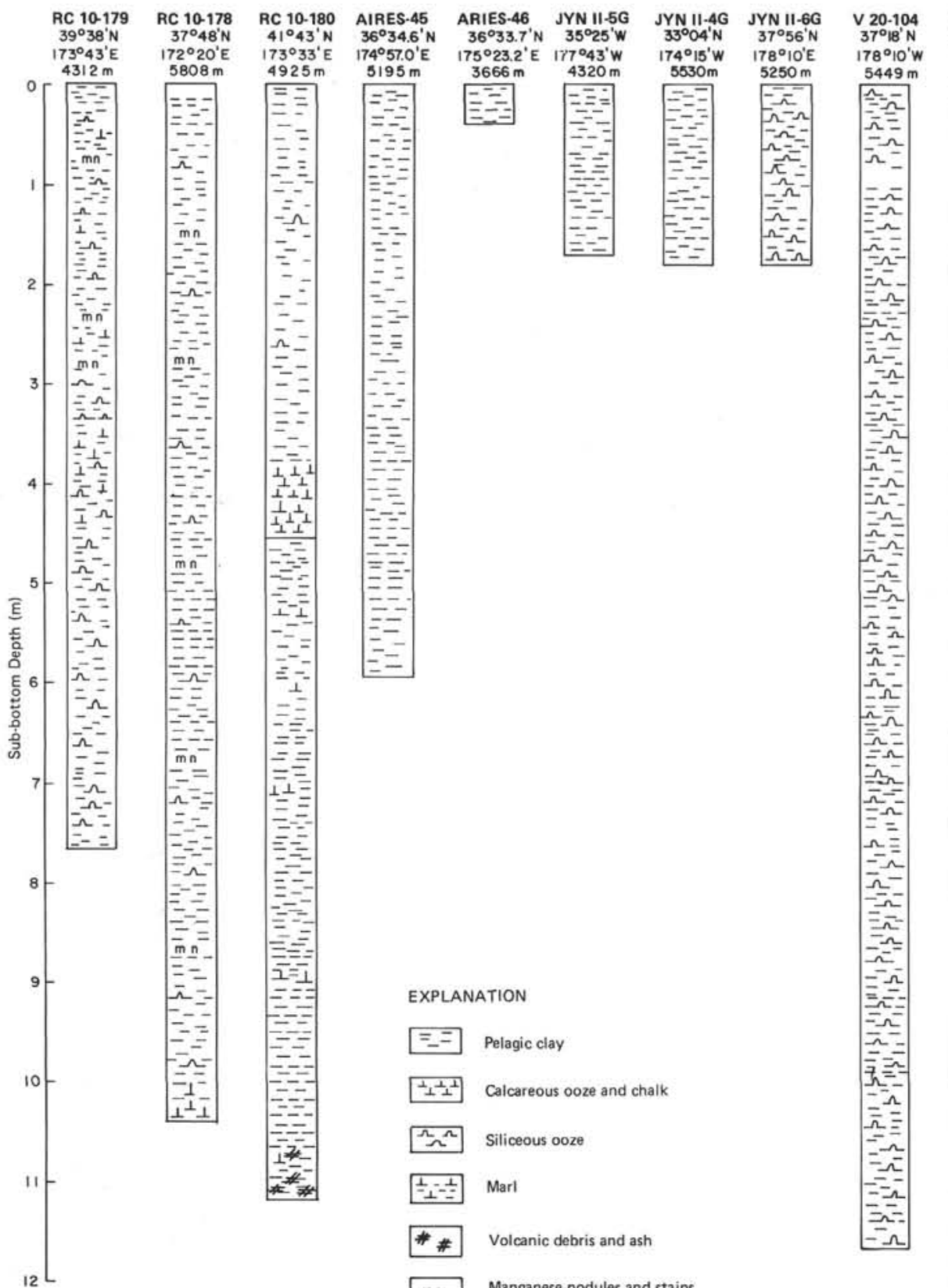

V 20-105
$39^{\circ} \mathrm{OO} / \mathrm{N}$

$\begin{array}{lllll}\text { AIRES }-48 & \text { AIRES }-46 & \text { V } 32.128 & \text { V } 32-127 \\ 36^{\circ} 33.4^{\prime} \mathrm{N} & 36^{\circ} 33.7 \mathrm{~N} & 36^{\circ} 27.5^{\prime} \mathrm{N} & 35^{\circ} 28.7^{\prime} \mathrm{N}\end{array}$

V 32.126 AIRES-49 V 20-103

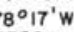

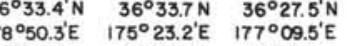

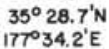

$35^{\circ} 19.1^{\prime} \mathrm{N}$

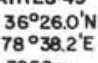

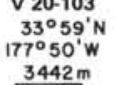

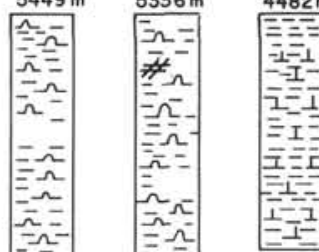

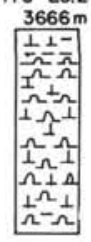

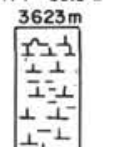

每

$3870 \mathrm{~m}$

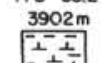

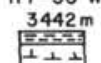




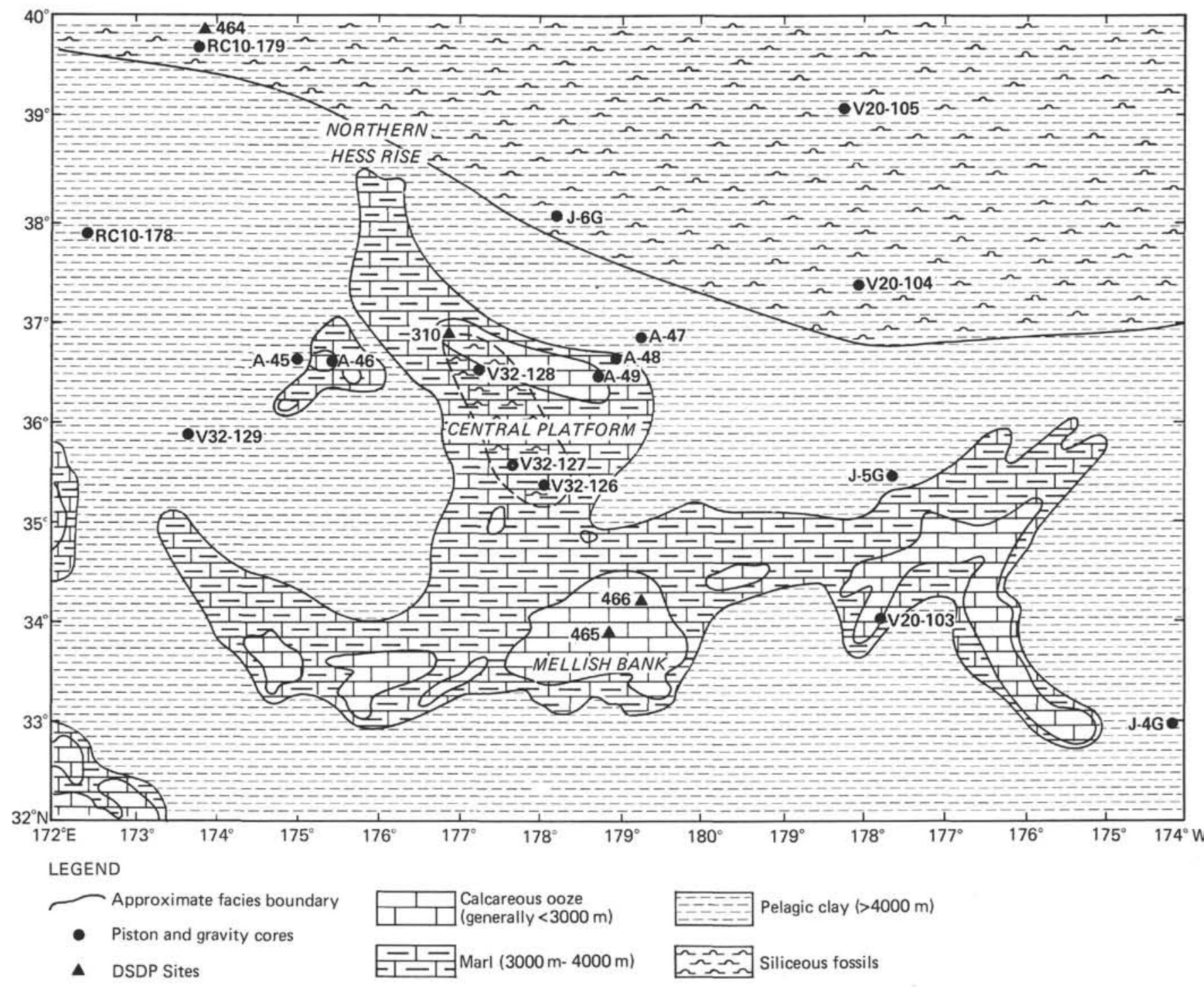

Figure 13. Generalized map of surface-sediment facies on Hess Rise and surrounding areas in the central North Pacific, determined by the compositions of surface sediments in piston cores (Fig. 12) and DSDP cores (Fig. 7).

to mudstone, calcareous ooze to chalk, and opal to chert often can be resolved acoustically and appear in seismic records as layers or seismic boundaries. Acoustic basement generally is volcanic rock. The definition of acoustic basement, however, depends on the power and type of seismic system used and, in places, it may correspond to limestone or chert. The difficulty in distinguishing volcanic rock from limestone on some seismic records is greatly influenced by the strong contrast in acoustic impedance between limestone and the overlying sediment, which causes most incident seismic energy to be reflected, so that seismic waves do not penetrate the volcanic rocks.

Figure 14 shows the relationships between drilling results and seismic stratigraphy on Hess Rise. In general, lithologic units correspond to the acoustic units, which assists in the interpretation of acoustic facies on the rise.

Three major acoustic units identified near Site 464 on northern Hess Rise can be related to the drilling results
(Figs. 7 and 14). These are (1) a lowest acoustic unit that shows coarse seismic layering, (2) a middle acoustic unit that has strong seismic layering, and (3) a top acoustic unit that is weakly layered to acoustically transparent. We recovered basalt $(16 \mathrm{~cm})$ from the top of the lowest unit, which strongly suggests that it corresponds to oceanic basement. The apparent seismic layering may have been caused by the seismic system. It is possible, however, that the basalt is the top sill in a sediment-sill sequence, and therefore that the layering may be real. The middle acoustic unit corresponds to a 219-meterthick sequence of nannofossil chalk and ooze, limestone, chert, and claystone. The top acoustic unit corresponds to the 89-meter-thick pelagic clay.

Drilling results at Site 310 (Larson, Moberly, et al., 1975) also can be correlated with the seismic stratigraphy (Figs. 7 and 14). The three acoustic units and their lithologies are (1) a bottom unit, not drilled, that probably corresponds to oceanic basement (volcanic rock), (2) a middle unit that acoustically is strongly layered, 

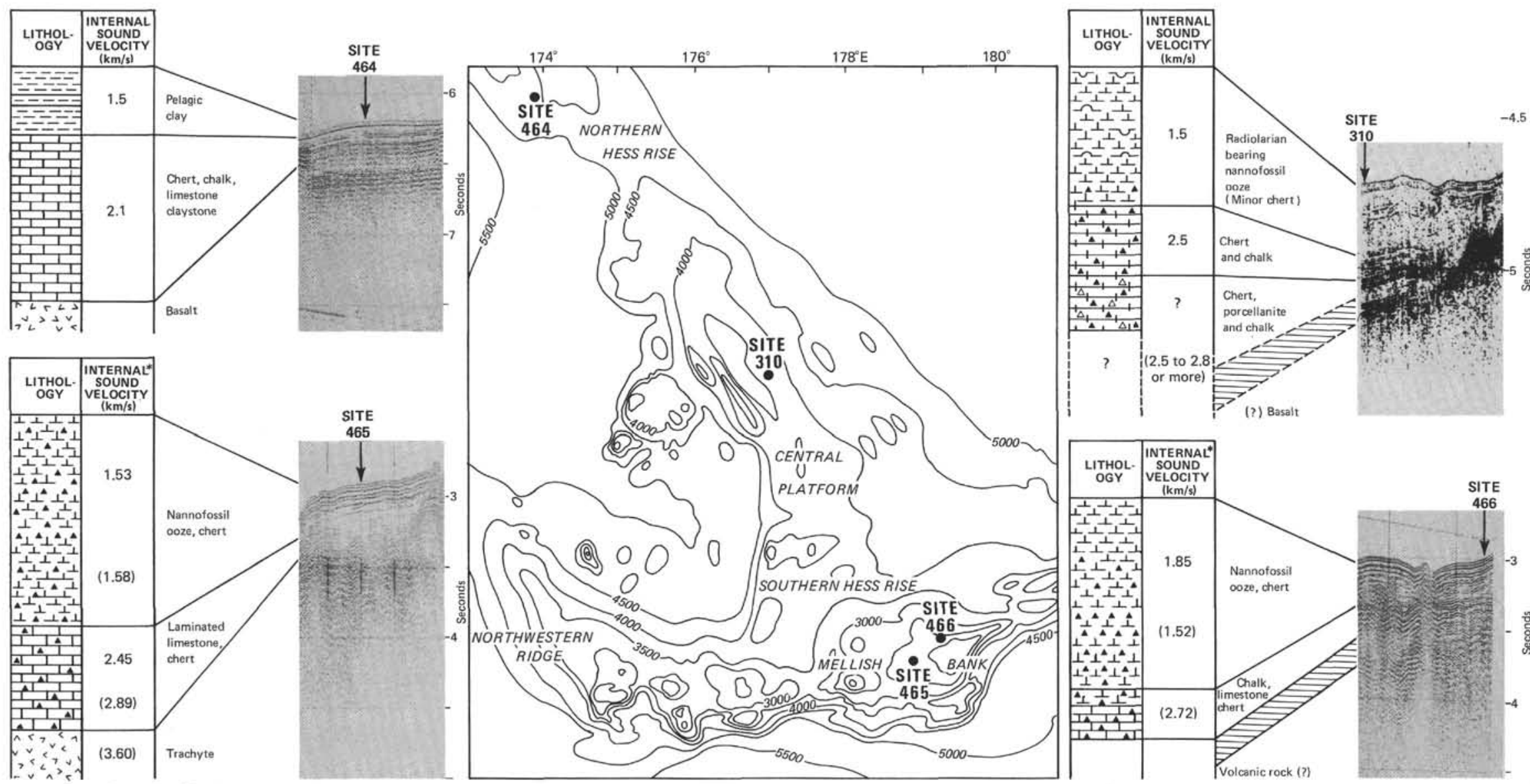

- Averages from laboratory

Figure 14. Correlation of seismic stratigraphy, interval sound velocity, and lithologies at sites drilled on Hess Rise. 
which is related to chert, porcellanite, and chalk lithologies, and (3) an upper unit, showing weak seismic layering, that relates to a sequence of nannofossil ooze with minor chert.

The two sites (465 and 466) drilled on Mellish Bank of southern Hess Rise are similar in that they have an irregular bottom unit that is nearly opaque acoustically, a middle unit that has strong reflecting layers, and an upper unit that ranges acoustically from nearly transparent to strongly stratified (Fig. 14). The consistent, strong acoustic stratification near the top of the upper unit is in part caused by reverberations, but some of the reflecting surfaces are real. The lowest unit (Fig. 7) is trachyte at Site 465 , and also probably is volcanic rock at Site 466 . The middle unit that has strong reflecting characteristics is limestone and chert at Site 465, and limestone, nannofossil chalk, and chert at Site 466. The upper unit at Site 466 corresponds to a thick sequence of nannofossil ooze and minor chert.

The seismic stratigraphy on Hess Rise, therefore, can be separated broadly into three major acoustic units that vary in composition, space, and time, based on the drilling results. The lowest unit corresponds to volcanic rock; it generally is acoustically opaque, although seismic reverberations make the unit appear layered in places. It is possible that the lowest unit may be welllithified limestone or chert on Hess Rise where the top reflector is extremely flat, but this has not been documented. A middle unit ranges widely in acoustic and thickness characteristics. Compositions are chert, chalk, limestone, and claystone (Site 464); chert, porcellanite, and chalk (Site 310); limestone and chert (Site 465); and limestone, chalk, and chert (Site 466). The top unit thickens and thins abruptly from place to place on Hess Rise. Compositions correspond to nannofossil ooze and minor chert (Sites $310,465,466$ ), and to pelagic clay (Site 464). These units can be traced across Hess Rise on the seismic-reflection records (Figs. 5 and 15-24), which are briefly discussed in the paragraphs that follow.

Leg 62 seismic-reflection records across northern Hess Rise show the changes in the acoustic units between the abyssal sea floor depths to the top of northern Hess Rise (Fig. 15, 0400Z to 1000Z, 16 August) and the changes in acoustic facies between northern Hess Rise and the central platform (Fig. 5). Particularly evident in Figure 5 is the change in thickness of the middle acoustic unit, which thickens or thins near faults. For example, this acoustic unit thickens between $0400 \mathrm{Z}$ and $0700 \mathrm{Z}, 22$ August (Fig. 5) and subsequently thins between $0700 \mathrm{Z}$ and $0730 \mathrm{Z}$, which indicates that the fault affected sediment accumulation. The strongly stratified unit that crops out along the sides of the graben (e.g., appproximately 2030Z, 21 August) probably is volcanic rock, and the apparent stratification would therefore be the result of seismic reverberations caused by the seismic system. Lithified limestone probably would have the same acoustic characteristics, and it is not possible to distinguish the two rock types (volcanic rock and limestone) on the seismic records. Figure 16 is the Conrad 10 seismic record across northern Hess Rise. The upper, nearly transparent unit thins over the rise and thickens northward in the basin.
Acoustic stratigraphy across the central platform is well portrayed on Figure 17. The middle and upper units both thicken and thin. Thickness changes in the middle unit are related to basement topography, which in turn is caused mostly by faulting. The upper unit shows the effects of local erosion (e.g., Fig. 17, 0200Z-0400Z, 23 August) and deposition (e.g., Fig. 17, 1200Z-1300Z, 22 August).

Figures 18,19 , and 20 show 10 -second-sweep seismicreflection profiles across northern Hess Rise and part of the central platform (Fig. 2). The western edge of northern Hess Rise is shown in Figure 18 at about 0300Z, 11 August. The upper acoustic unit on this record is separated from the middle unit by a strong reflector that may correlate with the youngest chert horizon. The middle unit has variable thickness, suggesting that there was significant relief and that sediment erosion, transport, and redeposition probably occurred. Figure 19 is a northeast-to-southwest seismic record between $38^{\circ}$ and $37^{\circ} \mathrm{N}$ that shows the gently sloping eastern side of Hess Rise (e.g., 0200Z-0600Z, 12 August) and the steep western escarpment. Grabens and horsts are well displayed on this record. Pinnacles that protrude above the sediments (e.g., 0330Z and 1000Z, 12 August, Fig. 19) probably are volcanic rocks. The small graben near 0900Z, 12 August (Fig. 19) has three distinct acoustic units that overlie an acoustically opaque basement. The unit that directly overlies acoustic basement is weakly stratified and has a constant thickness across the basin. The next overlying acoustic unit has a flat lower contact and a very irregular, undulating upper contact. The top acoustic unit is nearly transparent acoustically and more or less conforms to the top of the middle acoustic unit. It is apparent that the major relief (faulting?) formed after deposition of the lower, weakly stratified unit, probably during deposition of the next overlying unit. Judging from our drilling results, we speculate that the acoustic basement is basalt-or at least volcanic rock-and that the weakly stratified overlying acoustic unit is nannofossil chalk, limestone, and chert of Albian to latest Cretaceous age. The irregular acoustic unit is probably of latest Cretaceous and Paleogene age, and the upper unit is likely Neogene and Quaternary nannofossil ooze and marl.

The transition from the central platform to Mellish Bank on southern Hess Rise is shown in Figures 21 to 23. The Glomar Challenger Leg 32 and Vema 32 seismic records (Figs. 21 and 22) are of particular interest because the track lines (Fig. 2) progress across most of the central platform and over Mellish Bank. The seismically opaque basement probably is volcanic rock. The acoustic unit that directly overlies basement is both stratified and nearly transparent and, as elsewhere, thickens and thins depending on structural position. The middle and upper acoustic units, described above, can be distinguished in places (e.g., Fig. 21, 1400Z-1600Z, 24 September); in other parts of the seismic records (e.g., Fig. 21, 0600Z, 24 September) the separation is not as straightforward. All acoustic units become irregular on Mellish Bank. The irregularity of acoustic basement is particularly evident along the Leg 62 seismic record (Fig. 23, 1400Z1800Z, 23 August). Limestone, as determined by Site 

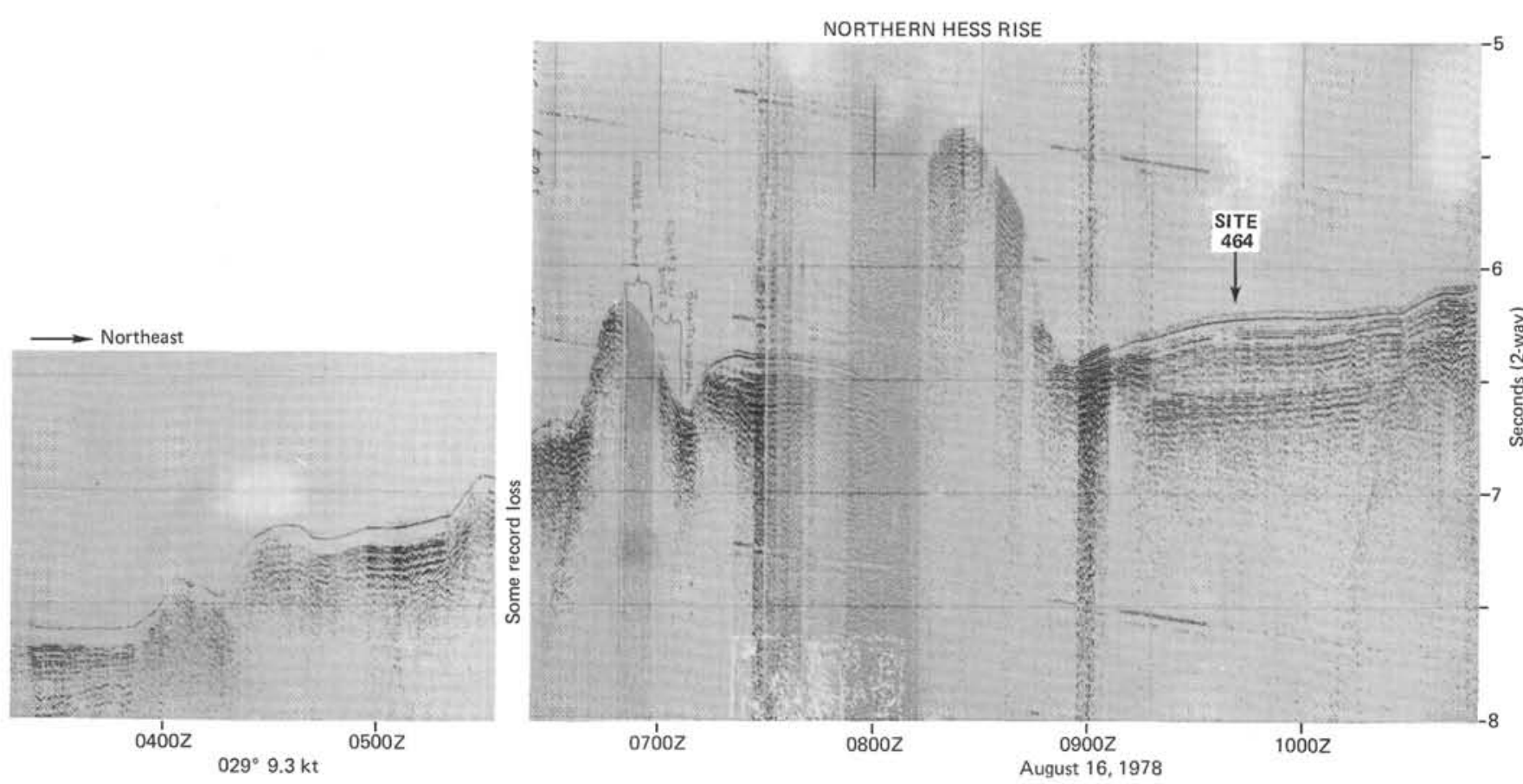

Figure 15. Five-second-sweep seismic-reflection record from Glomar Challenger Leg 62, showing Site 464 and the approximately south-to-north $\left(029^{\circ}\right)$ approach across northern Hess Rise.

465 drilling results, apparently filled basement lows and thereby decreased local relief during accumulation. The overlying nannofossil ooze and chert unit is thick near the crest of the rise (Fig. 22, 0000Z, 27 July; Fig. 23, $2100 \mathrm{Z}, 23$ August) and is mostly absent where the topography is rugged (Fig. 23, 1400Z-1800Z, 23 August), suggesting prolific erosion by bottom currents on and around the bathymetric highs.

The volcanic pinnacles on southern Hess Rise (Fig. 24) indicate the local relief across Mellish Bank. The small basin between the two pinnacles (Fig. 24, 0700Z, 16 August) contains sediment in the thick middle acoustic unit that probably was deposited from debris flows that cascaded off the sides of the surrounding pinnacles and escarpments.

Figure 25, a profile across part of Mellish Bank near Sites 465 and 466 , shows some topographic and seismic complexities. Irregular pinnacles are nearly sedimentfree, and intervening basins contain thick sediment bodies. The limestone unit (Albian-Cenomanian at both sites) can be traced acoustically through the basins and consistently has a nearly flat upper contact. The overlying nannofossil ooze and chert unit (Fig. 14) thickens and thins and changes in acoustic characteristics across Mellish Bank.

Figure 26 is a Vema 20 seismic record from south to north across the eastern ridge of southern Hess Rise to the Emperor Trough. The track line (Fig. 2) crosses southern Hess Rise, a deep basin, and Emperor Trough. Emperor Trough reaches a depth of more than 6750 meters at 0700Z, 31 May (Fig. 26). Hess Rise slopes down to the north through a series of block faults and volcanic pinnacles and reaches abyssal depths $(7 \mathrm{sec})$ at 0700Z-0800Z, 30 May. The topographic expression along this seismic record is extremely irregular and rough, particularly between $0000 \mathrm{Z}$ and $0800 \mathrm{Z}, 30 \mathrm{May}$.

\section{PALEOENVIRONMENTS}

Paleoenvironmental aspects of sediments recovered from sites on Hess Rise have been discussed in other parts of this paper, particularly in the section on lithofacies. In this section we specifically concentrate on the paleogeography and paleobathymetry of Hess Rise and discuss changes that occurred in the depositional environments during late Mesozoic and Cenozoic times.

The evolution of depositional environments of the central North Pacific Ocean, especially of its aseismic rises, can be described in sufficient detail only after reconstructions of paleobathymetry and paleogeography are considered. We have reconstructed the paleogeographic and paleobathymetric evolution based on proposed late Mesozoic and Cenozoic plate movements and from the probable subsidence history of Hess Rise (Fig. 27). The plate rotations have been carried out following the model of Lancelot (1978), because magnetic properties of the Leg 62 rocks from Hess Rise (Sayre, this volume) are in better agreement with this model than with previously published models (Winterer, 1973; van Andel et al., 1975).

Hess Rise is part of the Pacific Plate and has moved along a north-northwestward path for more than 100 m.y. The rise, now situated at approximately 35 to $45^{\circ} \mathrm{N}$ latitude, was at one time south of the equator; it moved north at rates which have been estimated from the model of Lancelot (1978). Its northern part must have crossed the equatorial region more than 100 m.y. ago. The concomitant large increase in accumulation rates just above the volcanic basement at Site 464 (Thiede and 

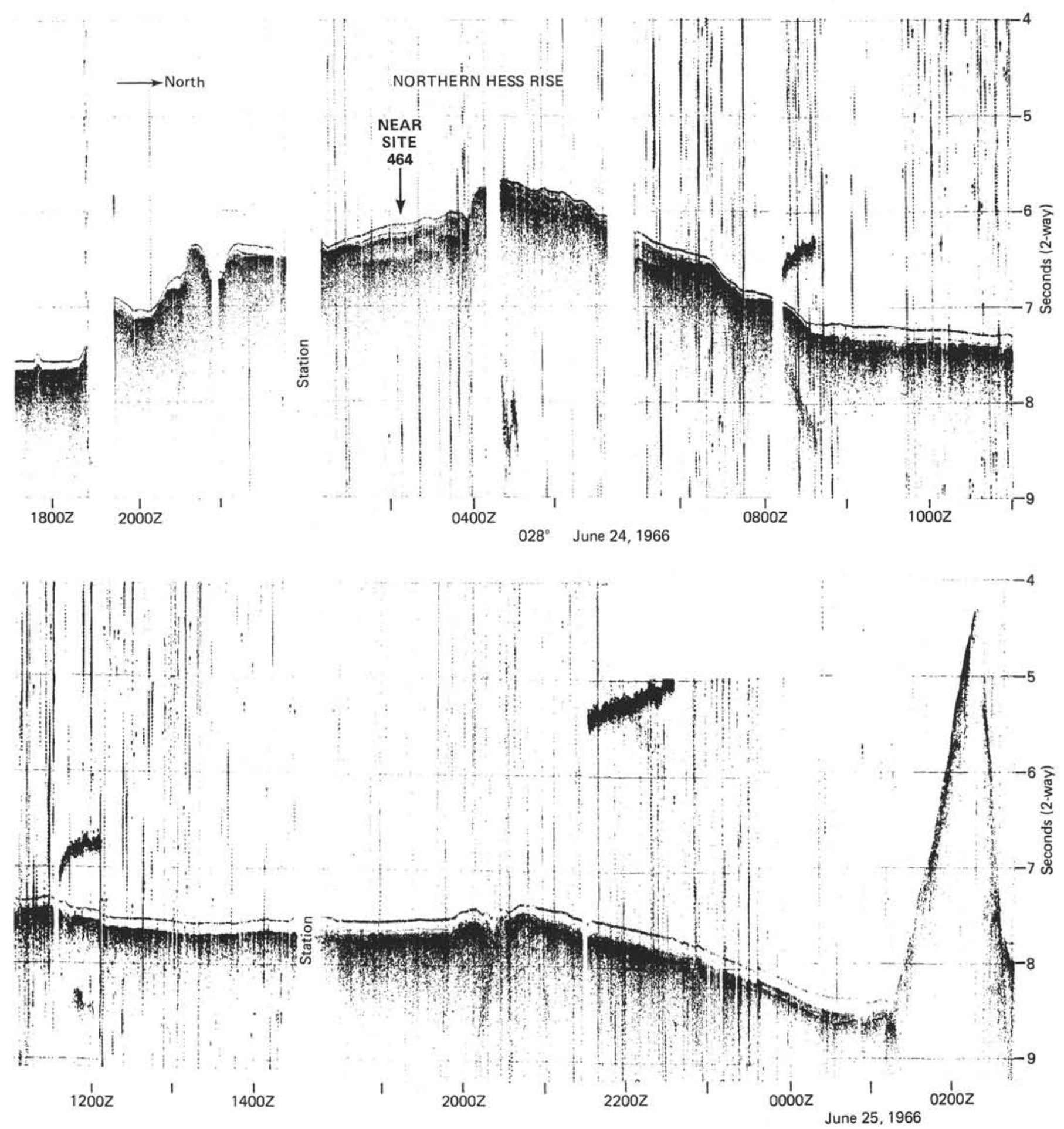

Figure 16. Ten-second-sweep seismic-reflection record from Conrad 10 across northern Hess Rise.

Rea, this volume) probably reflects the location of this site under the equatorial current regime where productivity was high (van Andel et al., 1975) and where the CCD was depressed more than usual in response to the high flux of calcareous particles to the sea floor (Berger and Winterer, 1974).

The sediments drilled on Hess Rise also suggest that this oceanic plateau subsided since initiation of its northward movement. We have attempted to quantify (Fig. 28) the rate of subsidence to determine the paleodepth of the depositional environments at different times (Thiede and Rea, this volume). These data suggest that the southern part of Hess Rise must have risen above the sea surface to form an archipelago of tropical islands during its early history (Fig. 27). Most of these islands sank below sea level during the Late Cretaceous 

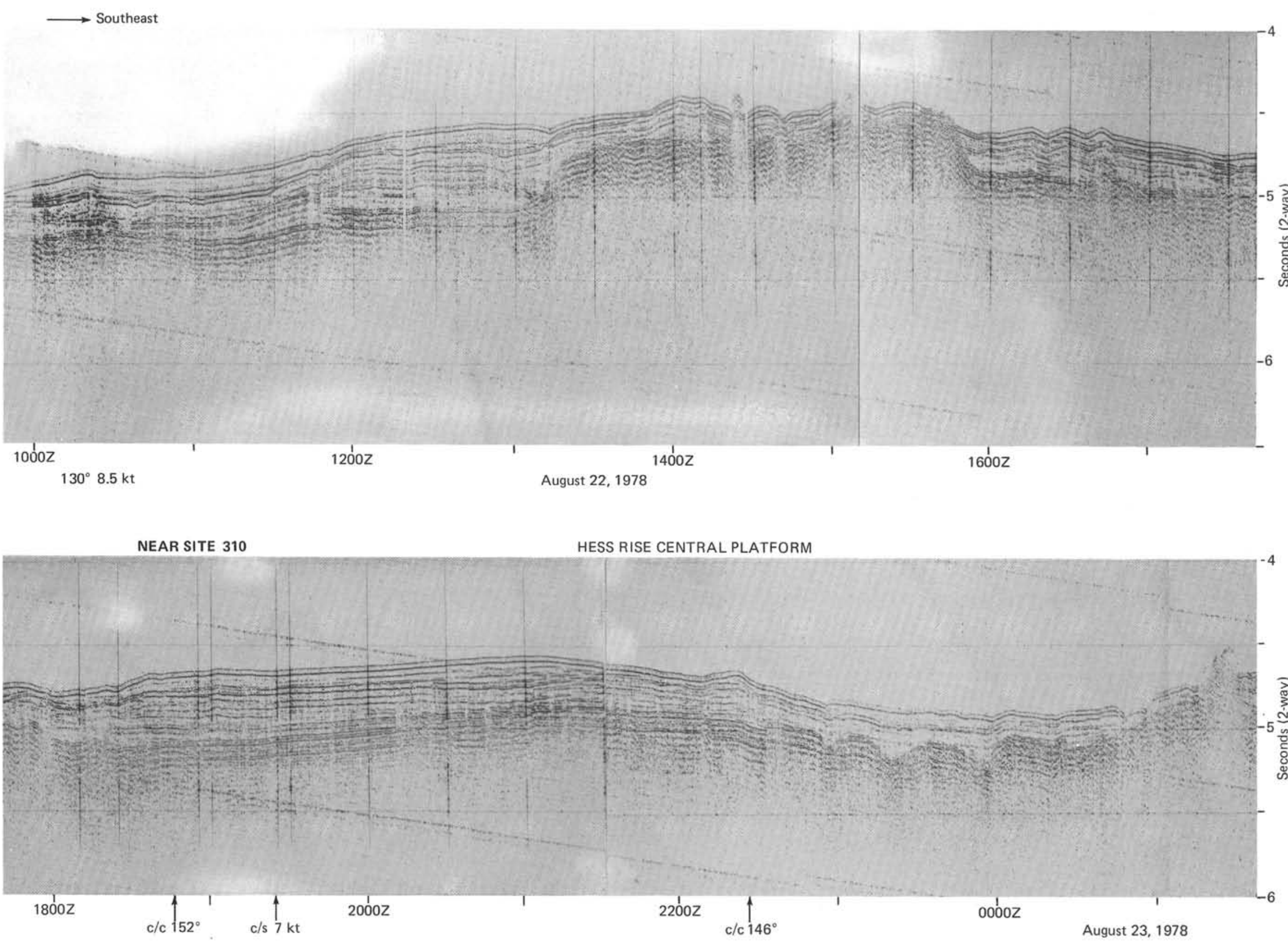


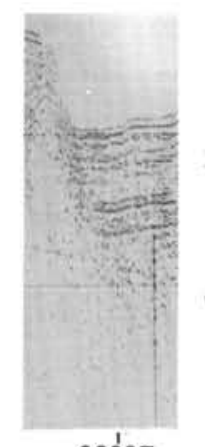

$020 \dot{0} z$

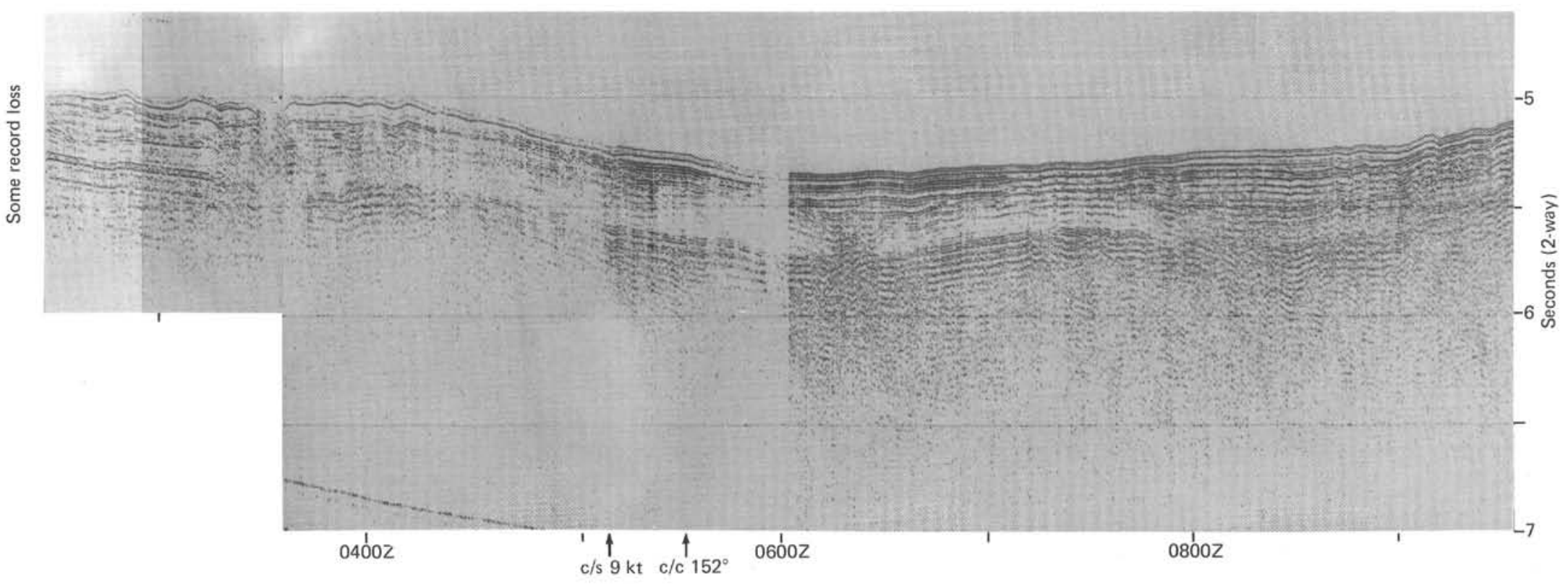

Figure 17. Five this profile. 

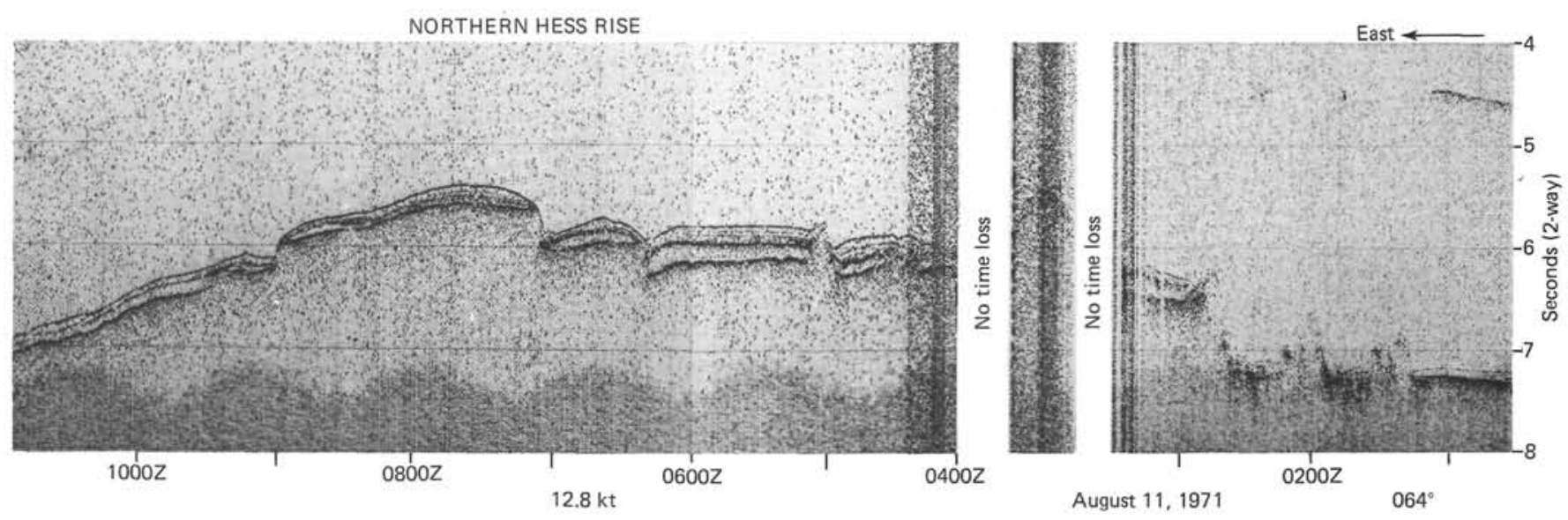

Figure 18. Ten-second-sweep seismic-reflection record from Aries Leg 7 across northern Hess Rise, showing the characteristic normal faults and acoustic stratigraphy.

as Hess Rise crossed the equatorial zone. Only individual volcanic peaks might have existed as islands until the early Tertiary.

The presence first of a chain of large islands and later of extensive shallow bank areas, must have disturbed the equatorial current regime as Hess Rise moved northward, and may have caused the development of a wide area of high surface-water productivity. This condition would have existed until the rise moved out of the region with continuing northward plate movement (Lancelot, 1978). Calcareous sediments with high concentrations of organic carbon (Dean et al., this volume) were deposited along the flanks of southern Hess Rise at relatively shallow water depths during this time, as documented by the benthic foraminifers (Boersma, this volume).

All four sites on Hess Rise had reached a position under an essentially sterile subtropical gyre during the Cenozoic, where accumulation rates were low and extensive erosion created long hiatuses. A thick pelagic clay sequence of Cretaceous to Miocene age (Doyle and Riedel, this volume; Sancetta, this volume) documents the position of Site 464 well below the CCD for long periods of time. Dissolution of calcareous material was also important at the other sites on Hess Rise at intermediate depths $(1500-2500 \mathrm{~m})$. These intermediate depths were expected to have been much less prone to calcite dissolution than they in reality proved to be.

Mass-accumulation rates of the sediment components (Thiede and Rea, this volume; Rea and Harrsch, this volume) are helpful for interpreting paleoenvironments. Calcareous components dominate the shallower parts of Hess Rise. However, at Site 464, on northern Hess Rise, more than 50 meters of carbonate-free pelagic clay represents a time span of as long as 88 m.y. (98 m.y. to 10 m.y. ago maximum), when the depositional surface was below the CCD and under low-productivity surface waters of the central North Pacific subtropical gyre.

Accumulation rates of the bulk sediment, as well as the dominant calcareous fraction, are highly variable and fluctuated from near 0 to more than $10 \mathrm{~g} \cdot \mathrm{cm}^{-2} \cdot 10^{-3}$ $\mathrm{yr}^{-1}$. The sites reveal a common pattern of high accumulation rates in the older part of the penetrated sequences. The transition from high to low accumulation rates is preserved only at Sites 464 and 465 , whereas hiatuses accompany the abrupt decreases in accumulation rates at Site 466. The values in the younger Cenozoic parts of the sedimentary sections are low (e.g., well below $\left.1 \mathrm{~g} \cdot \mathrm{cm}^{-2} \cdot 10^{-3} \mathrm{yr}^{-1}\right)$, but the records of these time spans are incomplete at all four sites, because of the hiatuses.

Accumulation rates during the earliest phases of rapid sediment deposition are variable from site to site. They reach the highest values at Site 465 and fluctuate widely, revealing considerable variability for the flux of calcareous material to the sea floor. Although it is clear that the detail of stratigraphic information available is not always sufficient to establish a precise timing of these fluctuations, and although data coverage of the different time units is uneven because of the variability of the sedimentation rates, the rapidity and frequency of changes are of themselves interesting. The significant fluctuations of accumulation rates, the sedimentary structures in the organic-matter-rich limestones at Sites 465 and 466 , and the reworked shallow-water material at the unconformity atop the Mesozoic section at Site 466 all document the variability and instability of this depositional environment.

Data for the siliceous components are more sparse than for the calcareous material, because siliceous fossils have not been preserved in many cores. Siliceous fossils at Site 464 accumulated relatively rapidly from 107 to $100 \mathrm{~m} . \mathrm{y}$. ago; they are absent in the pelagic-clay interval, but they occur again in modest amounts in the late Neogene. Siliceous fossils only sporadically occur in sediments of Sites 465 and 466.

Organic carbon rapidly accumulated in certain intervals during Early and mid-Cretaceous times at Sites 465 and 466. Fluxes of organic carbon, in terms of the average values calculated here, never exceeded $1 \mathrm{~g} \cdot \mathrm{cm}^{-2}$ $\cdot 10^{-3} \mathrm{yr}^{-1}$, and organic-carbon concentrations change rapidly over short intervals (Dean et al., this volume). It is possible that the flux rates of organic carbon to the 

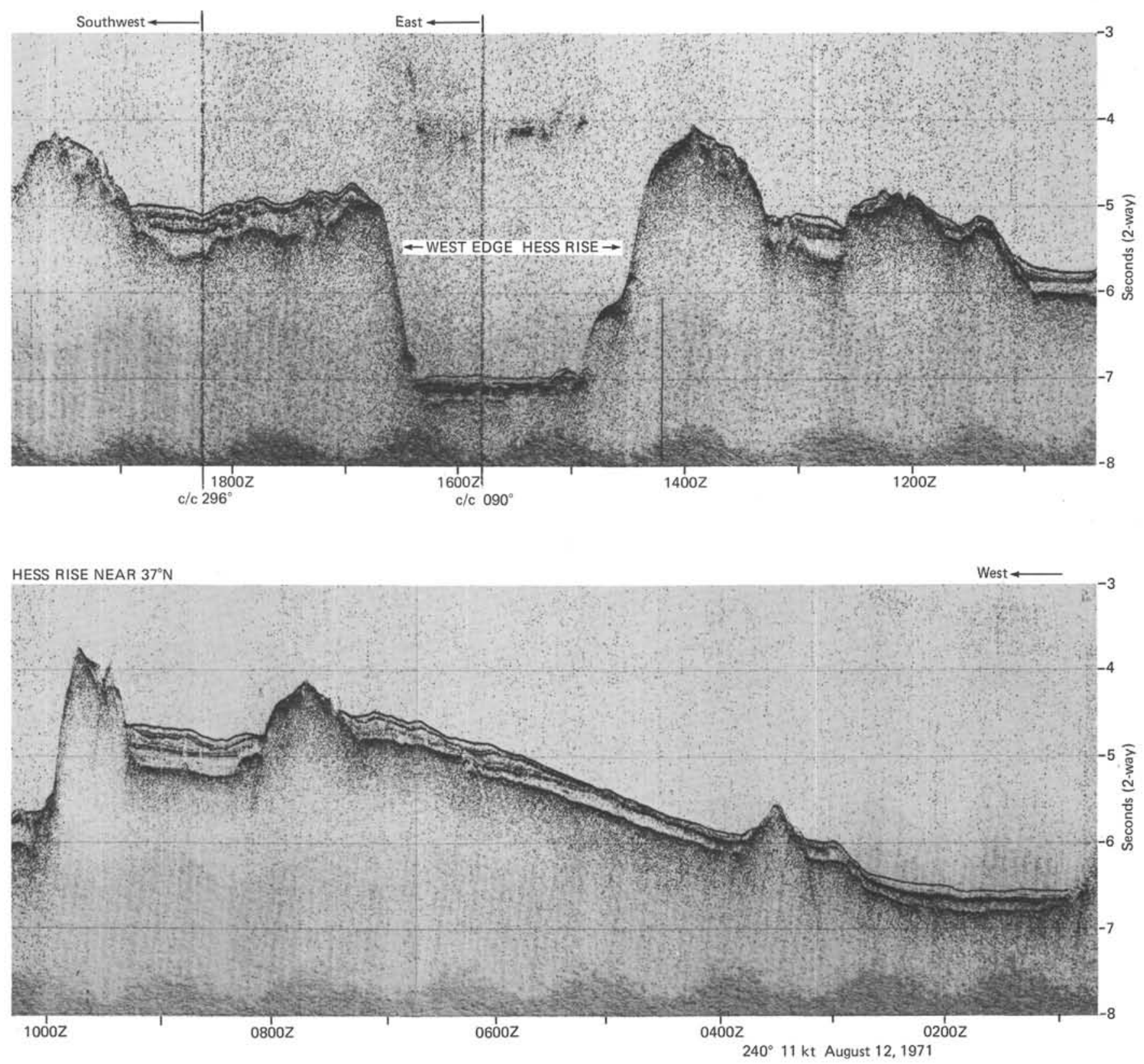

Figure 19. Ten-second-sweep seismic-reflection record from Aries Leg 7 across Hess Rise near $37-38^{\circ} \mathrm{N}$.

sediment were occasionally much higher than these data indicate.

Fluxes of biogenic material reflect more than the original production of either siliceous or calcareous components-or even of organic carbon-because reworking, dissolution, and diagenetic changes have altered their original values. We presume that the major preserved trends allow us to make inferences about the late Mesozoic and Cenozoic paleoenvironments of the central North Pacific Ocean. Anomalously shallow regions of the older parts of the Pacific basin occur near volcanic aseismic rises that approach and in places break through the sea surface. These anomalous regions create obstacles to the current regimes of the surface water masses, generating a region of greatly enhanced and higher-than-normal surface-water productivity. Local upwelling of nutrient-enriched waters to the sea surface and additional nutrient influx from large island runoff support this high productivity. If these bathymetric highs reach into the photic zone, or if parts rise above sea level as islands, they can support highly productive neritic depositional environments with local rapid and strong bottom currents. They also can receive erosional products from the adjacent subaerial volcanic islands. A modern analogy of such an environment probably can be observed in the depositional regime around the Galapagos Islands (Moore et al., 1973) in the eastern tropical Pacific Ocean.

The sedimentary sections recovered during Leg 62 on Hess Rise document the depositional history of a large 


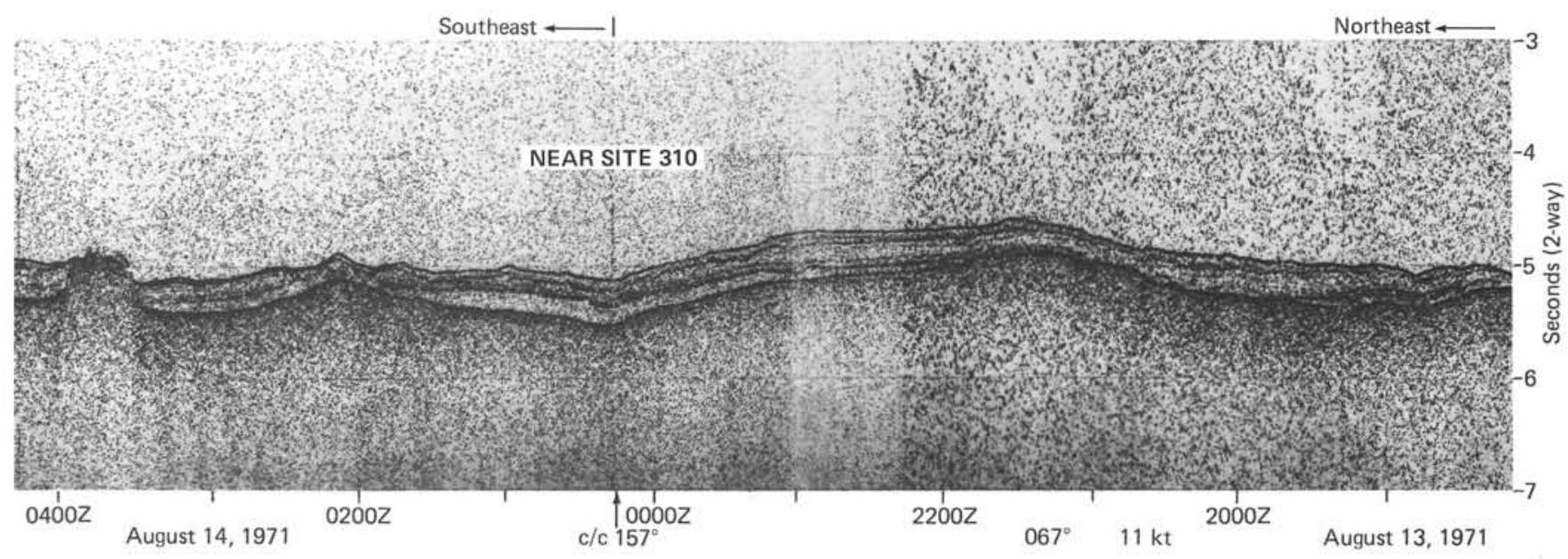

Figure 20. Ten-second-sweep seismic-reflection record from Aries Leg 7 across the central platform of Hess Rise near Site 310.

central Pacific oceanic plateau or aseismic rise, built during a phase of intensive Early Cretaceous volcanic activity south of the equator, which once represented a large tropical volcanic archipelago (Fig. 27). These islands rapidly subsided after their formation, but parts of the aseismic rise apparently had shoal areas for a long time as this part of the Pacific Plate moved northward across the Equator, into the central subtropical and temperate North Pacific Ocean.

The bulk-accumulation rates of the sediments were high during the middle Cretaceous history of the southern part of Hess Rise (Sites 465 and 466), because this region was situated far above the CCD and because it received an additional input of displaced shallow-water material. The traverse of the shallow regions across the westward-flowing equatorial current generated a timetransgressive pelagic depositional environment. This was characterized by highly variable accumulation rates (Site 465), development of hiatuses (Sites 465 and 466), and accumulation of sediment with high concentrations of siliceous fossils typical of highly productive surface water masses, which in part resulted in the common occurrence of chert in the Upper Cretaceous sequences. The depositional environment during passage beneath the equatorial zone is expressed in the sedimentary record of all Leg 62 sites by higher-than-usual accumulation rates of calcareous pelagic sediment. The effect of the equatorial crossing can be documented best at Site 464 , on northern Hess Rise. This site occupies the deepest and the northernmost location drilled during Leg 62 . The zone of high-carbonate accumulation rates is therefore 100 to $110 \mathrm{~m} . \mathrm{y}$. old, and it is accompanied by high accumulation rates of siliceous fossils, whereas during approximately the past 100 m.y. the depositional environment of Site 464 has been characterized by very slow accumulation of pelagic and siliceous clay.

Thick, laminated, organic-carbon-rich, limestone and chalk deposits penetrated near the bottom of Holes $465 \mathrm{~A}$ and 466 document the traverse of southern Hess Rise under the equatorial divergence. A strong midwater oxygen minimum had developed as a result of the high surface-water productivity, and at the same time bottom-water currents flowed at speeds sufficient to erode and sort the soft, fine-grained pelagic sediments (Dean et al., this volume).

The sites on Hess Rise had subsided into intermediate and deep waters by the time they reached the sterile subtropical to temperate central North Pacific. The calcareous, pelagic components of the Cenozoic sediment are therefore either dissolved (Site 464) or moderately well preserved (Sites 310, 465, and 466). At the latter three sites, climatically induced shifting of water masses throughout the Neogene are recorded in planktonic faunal assemblages (Vincent, this volume). The siliceous microfossils recovered in the Neogene section of Site 464 document the arrival of this site at an area close to the temperate to cool water masses of the northern North Pacific Ocean (Sancetta, this volume). The continuity of the Cenozoic sedimentary sequences was interrupted by erosion.

\section{TECTONIC EVOLUTION OF HESS RISE}

The evolution of the western Pacific during the Cretaceous and early Tertiary was complicated by changes in spreading-ridge orientations, ridge jumping, rapid growth and movement of triple junctions, formation of large oceanic plateaus, and mid-plate volcanism that overprinted older crust (Larson and Pitman, 1972; Winterer, 1973; Moberly and Larson, 1975; Lancelot and Larson, 1975; Winterer, 1976; Hilde, Isezaki, and Wageman, 1976; Hilde, Uyeda, and Kroenke, 1977; Lancelot, 1978; Watts et al., 1980; among many others). The long Cretaceous magnetic quiet period (about 110-85 m.y. ago) added to the complications, because magnetic-anomaly patterns cannot be used to map sea floor that formed during that time interval.

We must rely on studies of present-day topography, seismic-reflection records, gravity data, drilling results, and magnetics of surrounding younger ocean floor to reconstruct the geologic history of Hess Rise. Ambiguities are caused by the position of the rise near the intersection of the Emperor Trough and Mendocino Fracture Zone, and by the structural and possibly thermal overprinting by volcanism of seamount chains. The major 

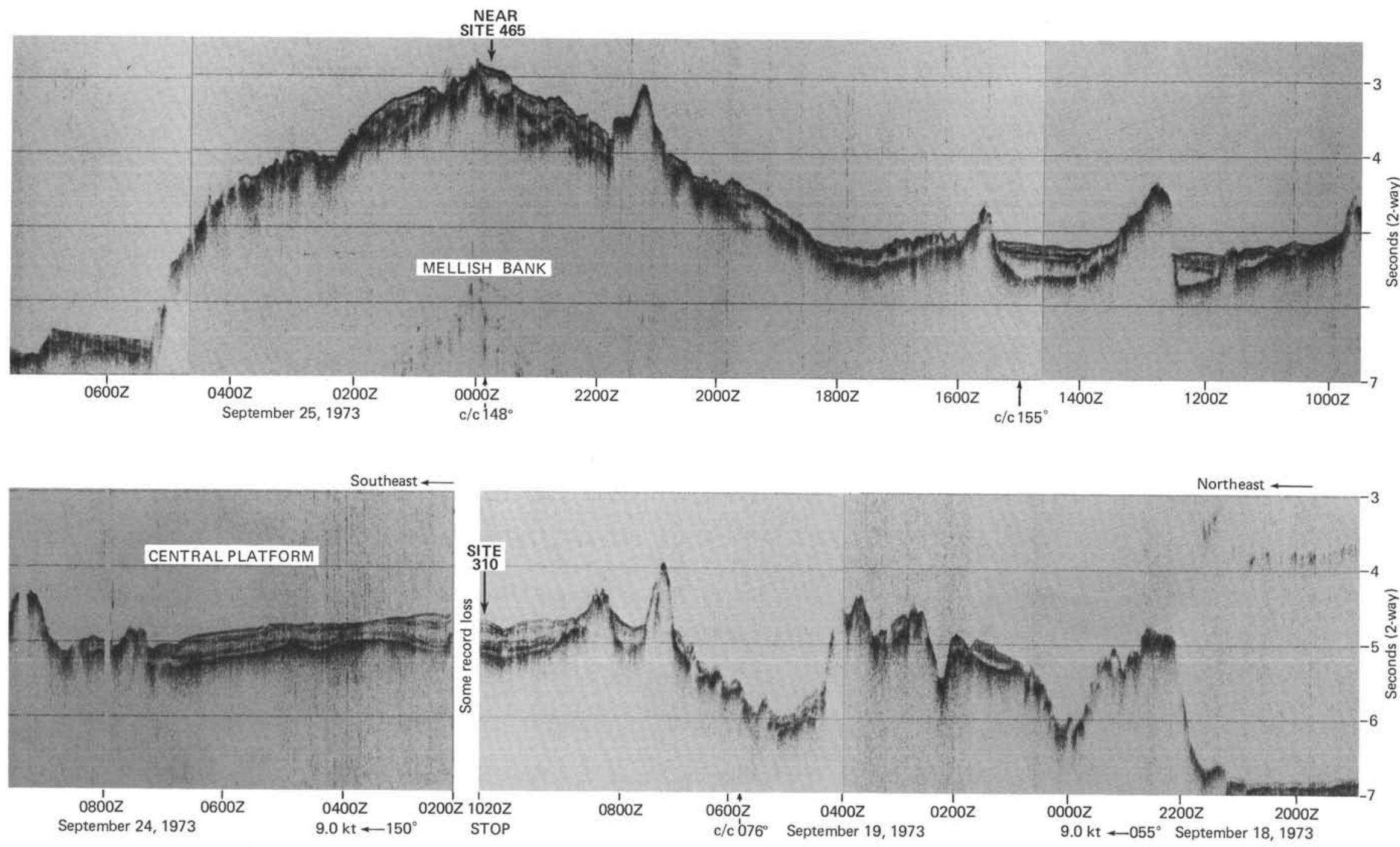

Figure 21. Ten-second-sweep seismic-reflection record from Glomar Challenger Leg 32 across Hess Rise from the central platform to Mellish Bank near Site 465. 


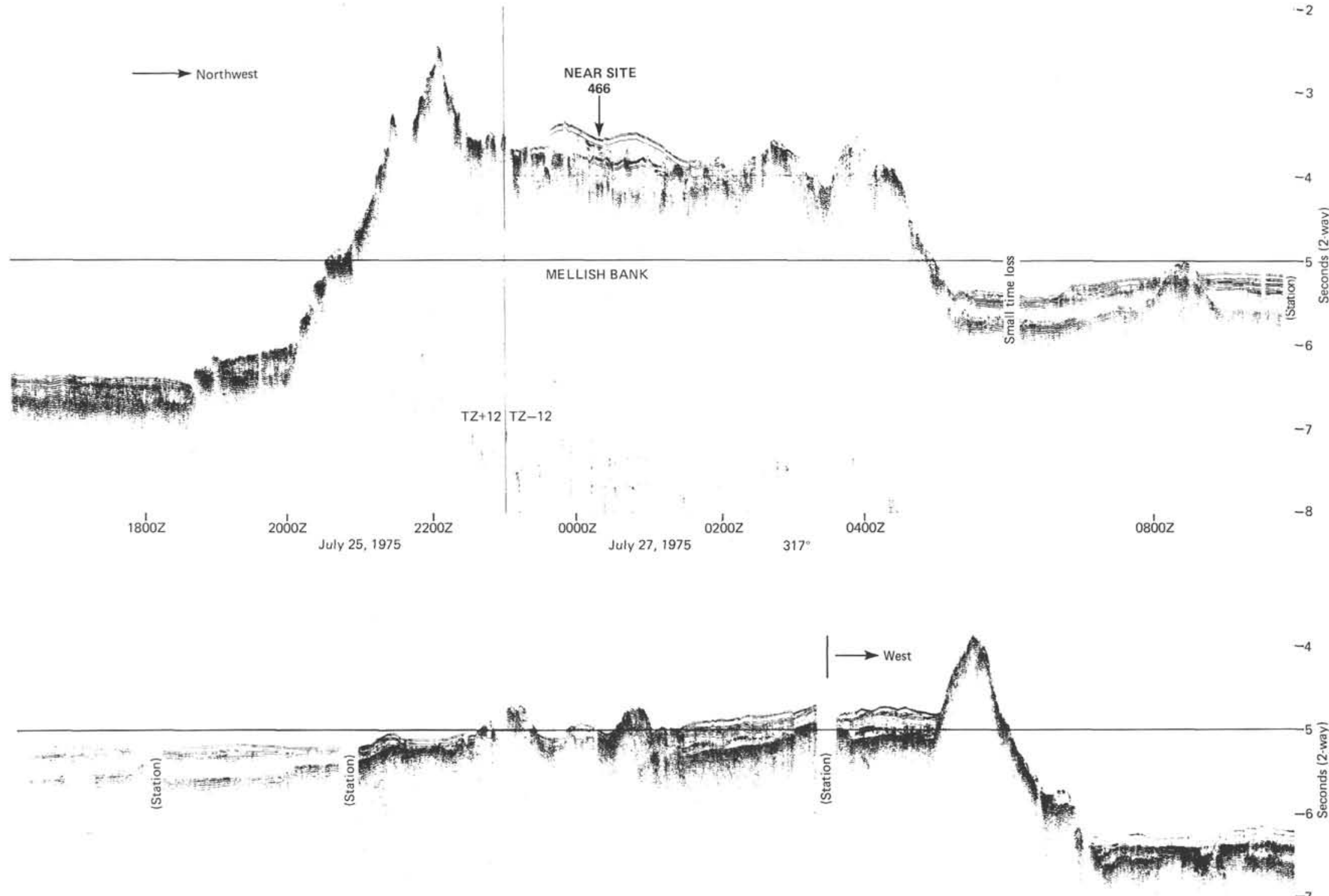



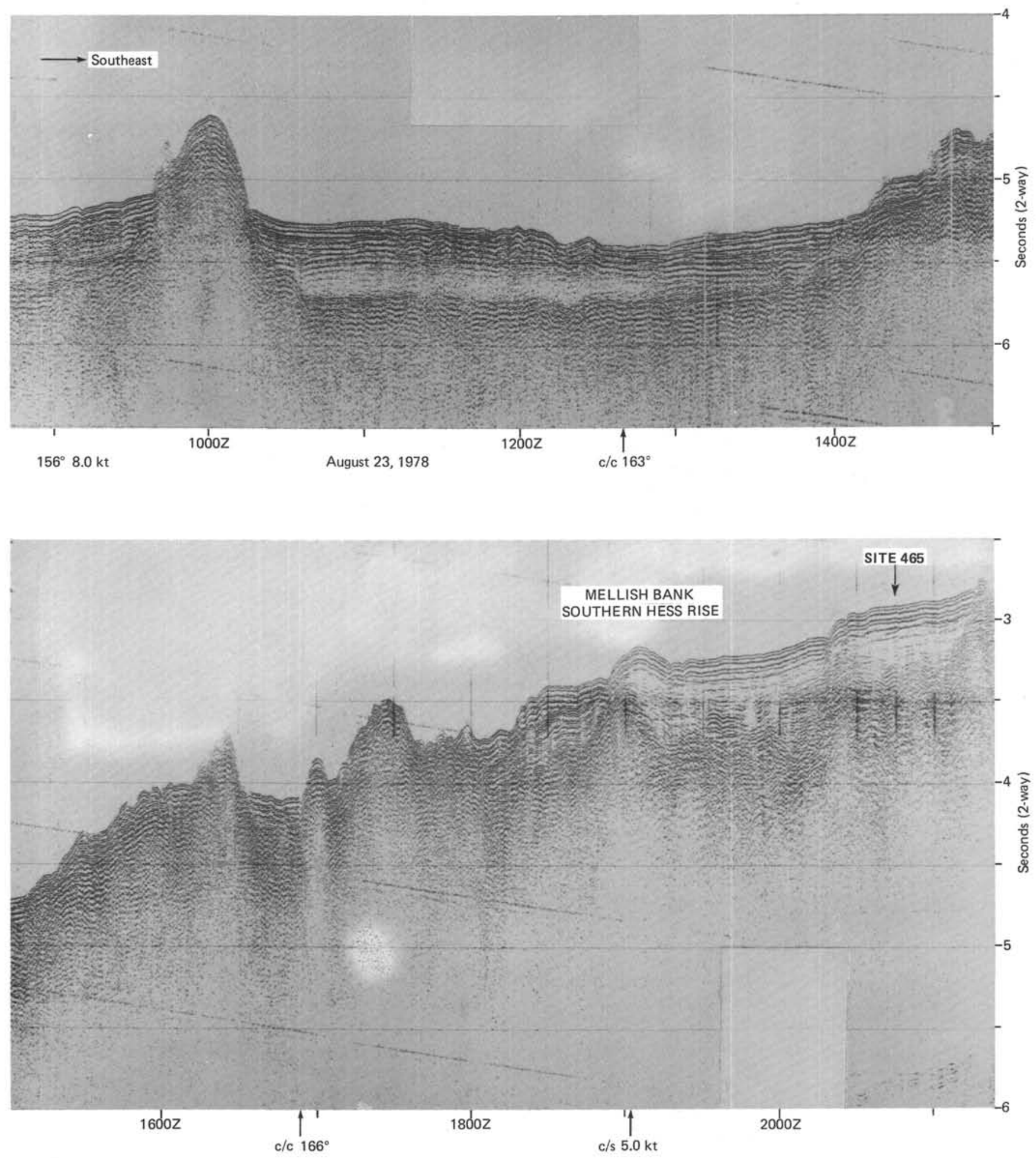

Figure 23. Five-second-sweep seismic-reflection record from Glomar Challenger Leg 62 across the central platform of Hess Rise to Site 465.

age relationships and structures of the North Pacific Ocean (Figs. 29 and 30) were described and discussed by Hilde, Isezaki and Wageman (1976) and Hilde, Uyeda, and Kroenke (1977). The data we obtained from the sites drilled on Hess Rise are compatible with the interpreted origin of Hess Rise suggested by Hilde, Isezaki, and Wageman (1976, pp. 222-226); they based their interpretations on patterns of magnetic anomalies in the northwest Pacific Ocean (Fig. 29), some dredge-haul data from Shatsky Rise, and the DSDP cores from Shatsky Rise and Hess Rise. Their interpretations, summarized here, present a possible mechanism for the 

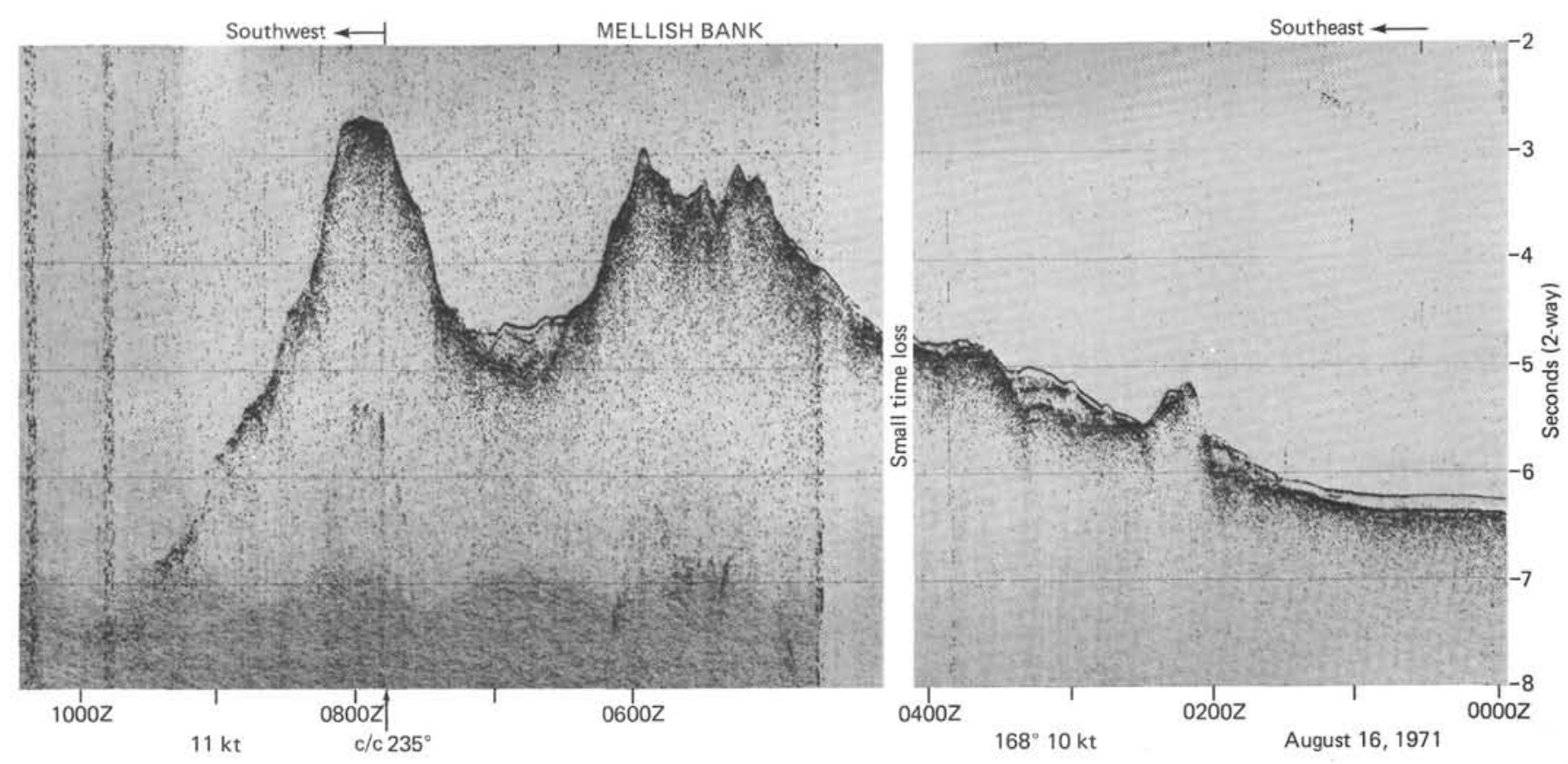

Figure 24. Ten-second-sweep seismic-reflection record from Aries Leg 7 across Mellish Bank, southern Hess Rise.

early evolution of Hess Rise, and also review the early evolution of the northwest Pacific Ocean basin.

Hess Rise probably formed along a ridge-ridge-ridge $(r-r-r)$ triple point, at the junction of the Kula, Farallon, and Pacific Plates. This origin is similar to that proposed for Shatsky Rise (Hilde, Isezaki, and Wageman, 1976), except that Shatsky Rise formed earlier (142-116 m.y. ago) than Hess Rise (116-95 m.y. ago). Figure 31 shows the proposed origin of Shatsky and Hess Rises. Shatsky Rise evolved along a r-r-r triple junction between the Kula, Farallon, and Pacific Plates, in the time interval between Magnetic Anomalies M-26 and M-20, followed by separation of the two ridges (Kula-Pacific and Pacific-Farallon) by a transform fault where they previously have joined at the time of Anomaly M-20. The transform fault increased in length along the long axis of Shatsky Rise as spreading continued. Separation of the two ridges increased with time as the Pacific Plate accreted more rapidly along its northwest side. The Kula-Pacific Ridge then grew from its northeast end as spreading continued after the time of Magnetic Anomaly M-20 with the formation of several northweststriking transform faults, until about the time of Anomaly M-13 to M-10, when the Pacific-Farallon Ridge changed spreading direction by $25^{\circ}$ clockwise. The Pacific-Farallon Ridge subsequently migrated more readily to the northeast along the Shatsky Rise transform fault, until the northwest end of this ridge caught up with the northeast end of the Kula-Pacific Ridge and the r-r-r triple junction formed at the northeast end of Shatsky Rise at about the time of Anomaly M-4.

The new r-r-r triple junction was disrupted at the north end of Shatsky Rise sometime after the time of Anomaly M-4, and during this time the Pacific-Farallon Ridge was separated from the Kula-Pacific Ridge by a southeast-trending transform fault. The triple junction migrated to the southeast until about 95 to 110 m.y. ago. Hess Rise was formed sometime between 116 and 95 m.y. ago, probably during the triple-junction migration.

While the north end of the Pacific-Farallon Ridge was migrating to the southeast, the Kula-Pacific Ridge continued to migrate to the northwest as the Pacific Plate accreted along its northwestern edge. The KulaPacific Ridge was probably subducted in a trench to the northwest about this time, which left the Kula-Farallon Ridge and the Pacific-Farallon Ridge either joined directly or connected by a transform fault in the vicinity of what is now the southeastern edge of Hess Rise. A third ridge developed, the new Kula-Pacific Ridge, extending west from the junction of the other two ridges, again forming an $\mathrm{r}-\mathrm{r}-\mathrm{r}$ triple junction (see imaginary QZ-2 on Fig. 31). This junction then migrated to the northeast as an r-r-r triple junction during the Cretaceous magnetic quiet period and continued into the Cenozoic. Meanwhile, the western end of the new KulaPacific Ridge moved to the north-northwest, forming the Emperor Trough. Therefore, according to the interpretation of Hilde, Isezaki, and Wageman (1976), the Emperor Trough was a left-lateral transform fault between the Kula Plate to the east and the Pacific Plate to the west.

Emperor Trough (Erickson et al., 1970) is an important feature for understanding the tectonic evolution of the Pacific Plate. Larson and Chase (1972) speculated that the Emperor Trough is a former spreading center that changed to a transform fault about 100 m.y. ago, when the northern part of the Hawaiian spreading center was approximately coincident with the Emperor Trough. The northeast auxiliary spreading center jumped to the southeast, intersecting the Hawaiian spreading center at 


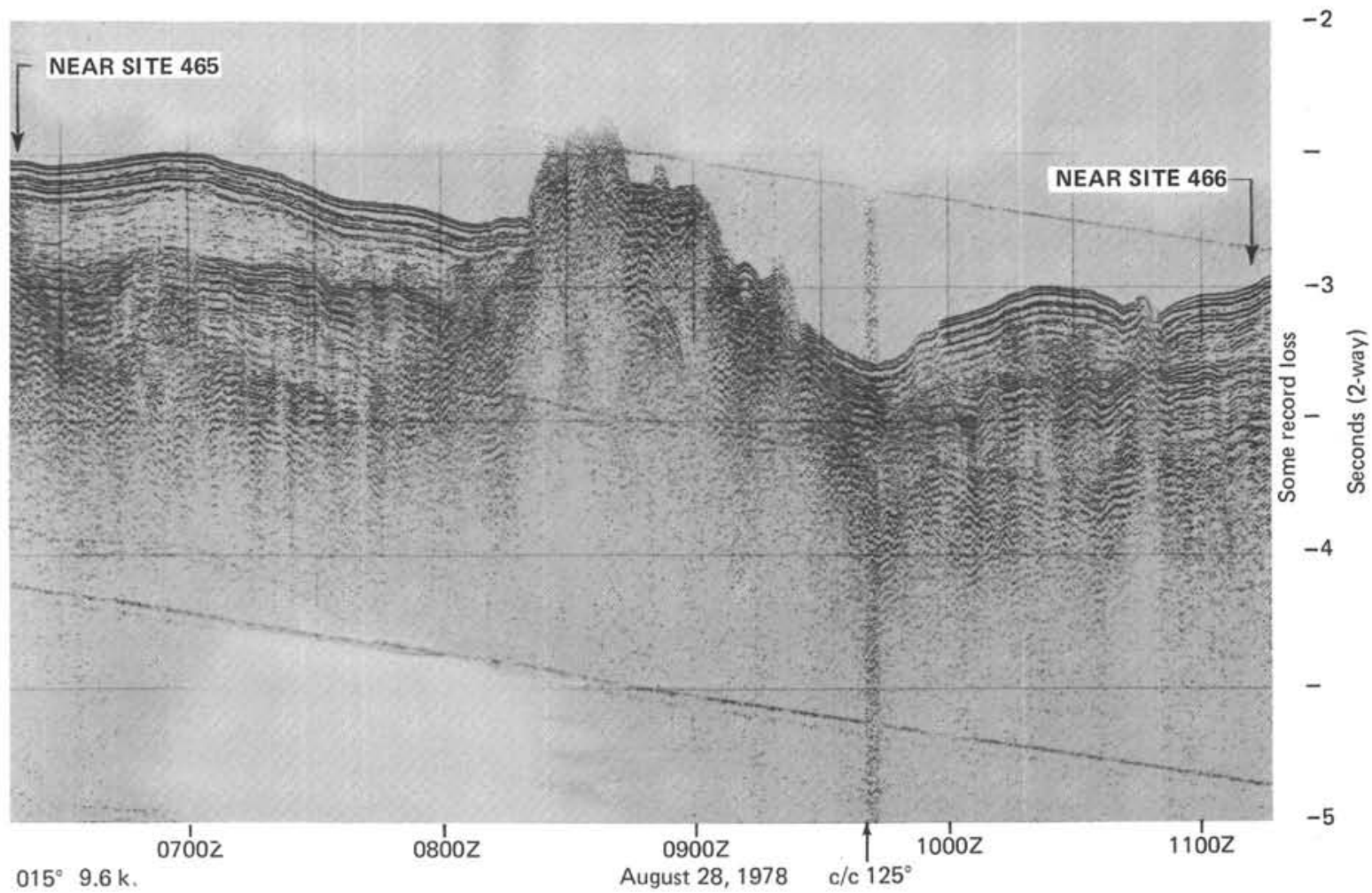

$-2$

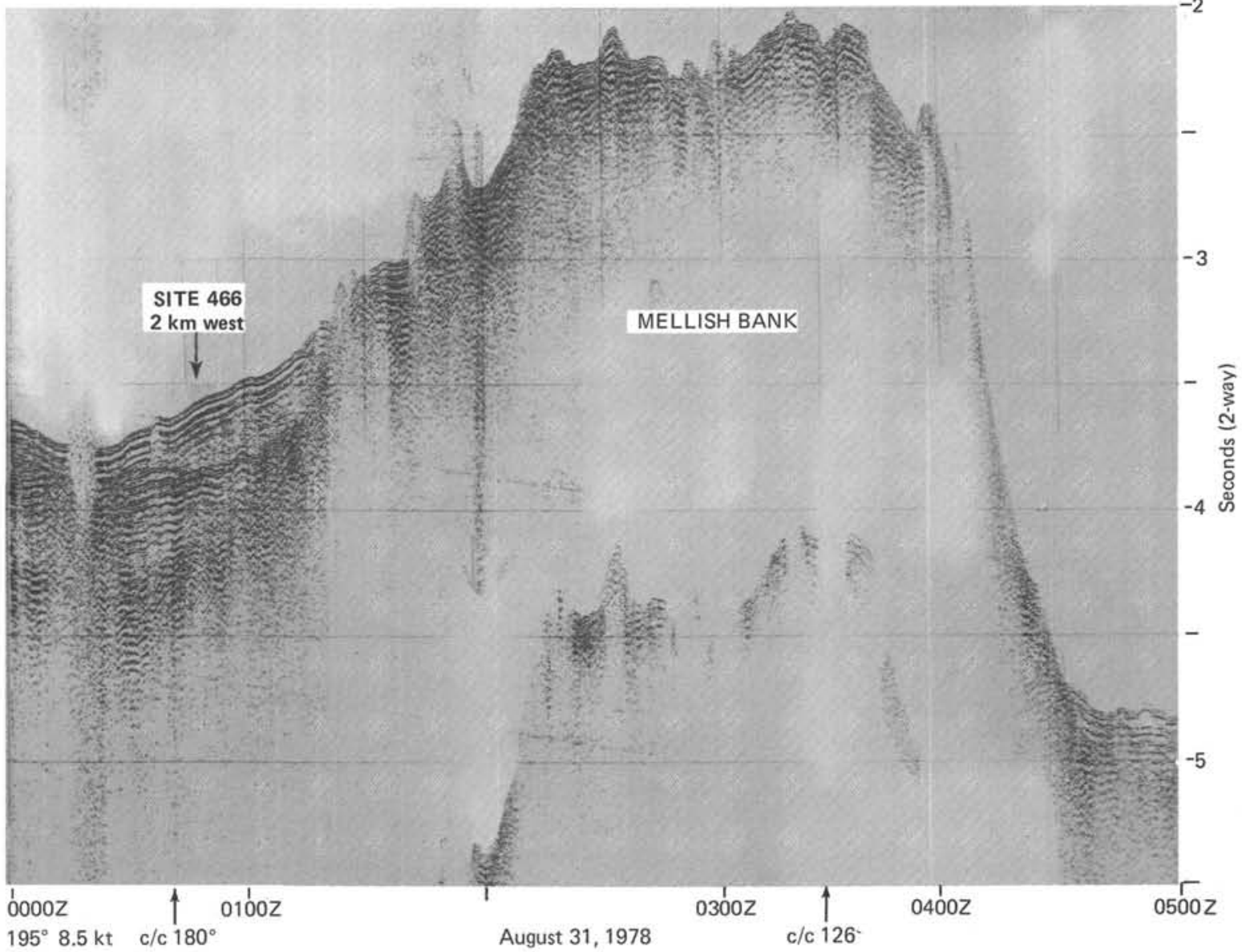

Figure 25. Five-second-sweep seismic-reflection record from Glomar Challenger Leg 62 between Site 465 and Site 466 and a north-to-south crossing of Mellish Bank. 

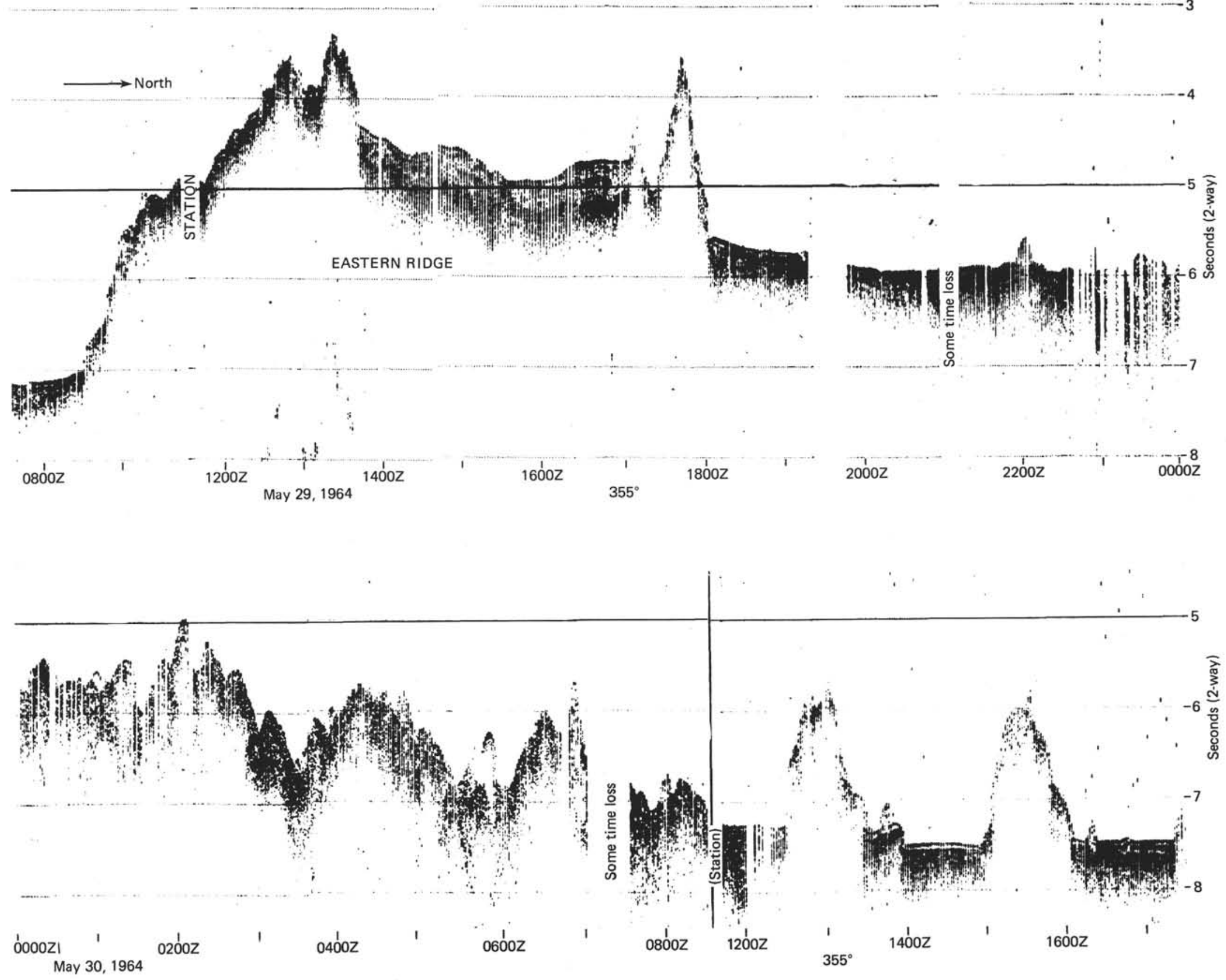


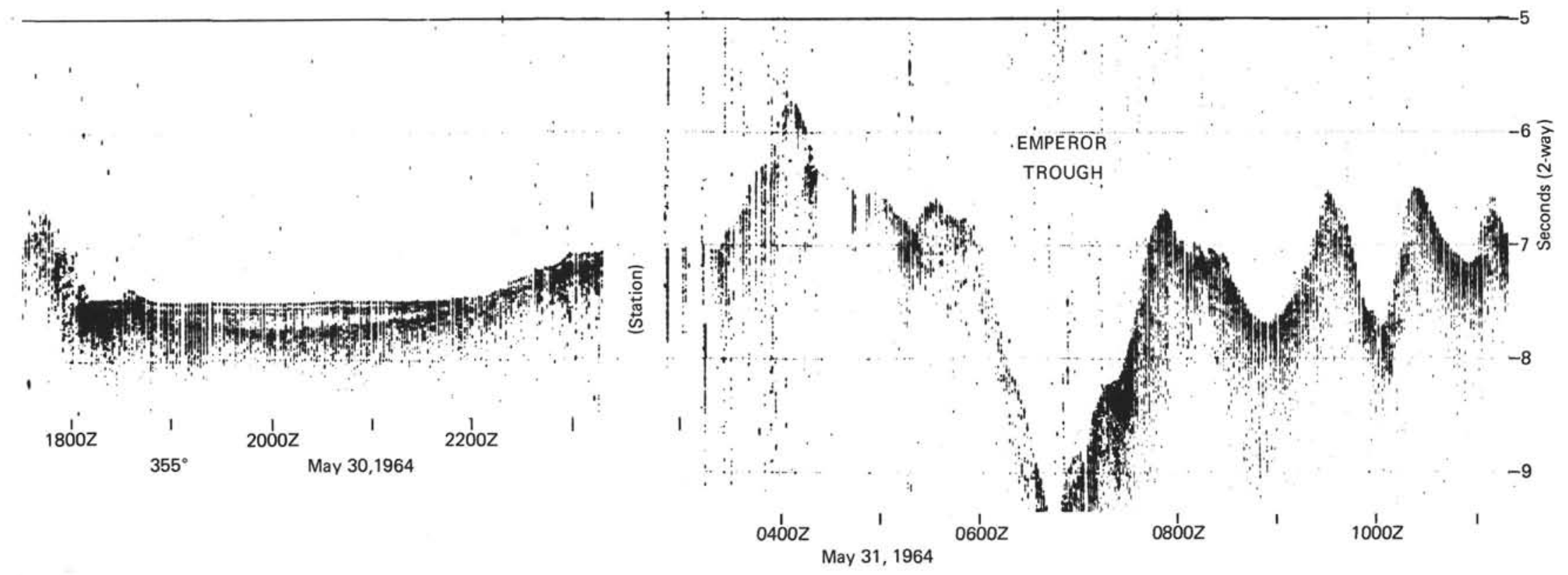

Figure 26. Ten-second-sweep seismic-reflection record from Vema 20 across Hess Rise and Emperor Trough from south to north. 

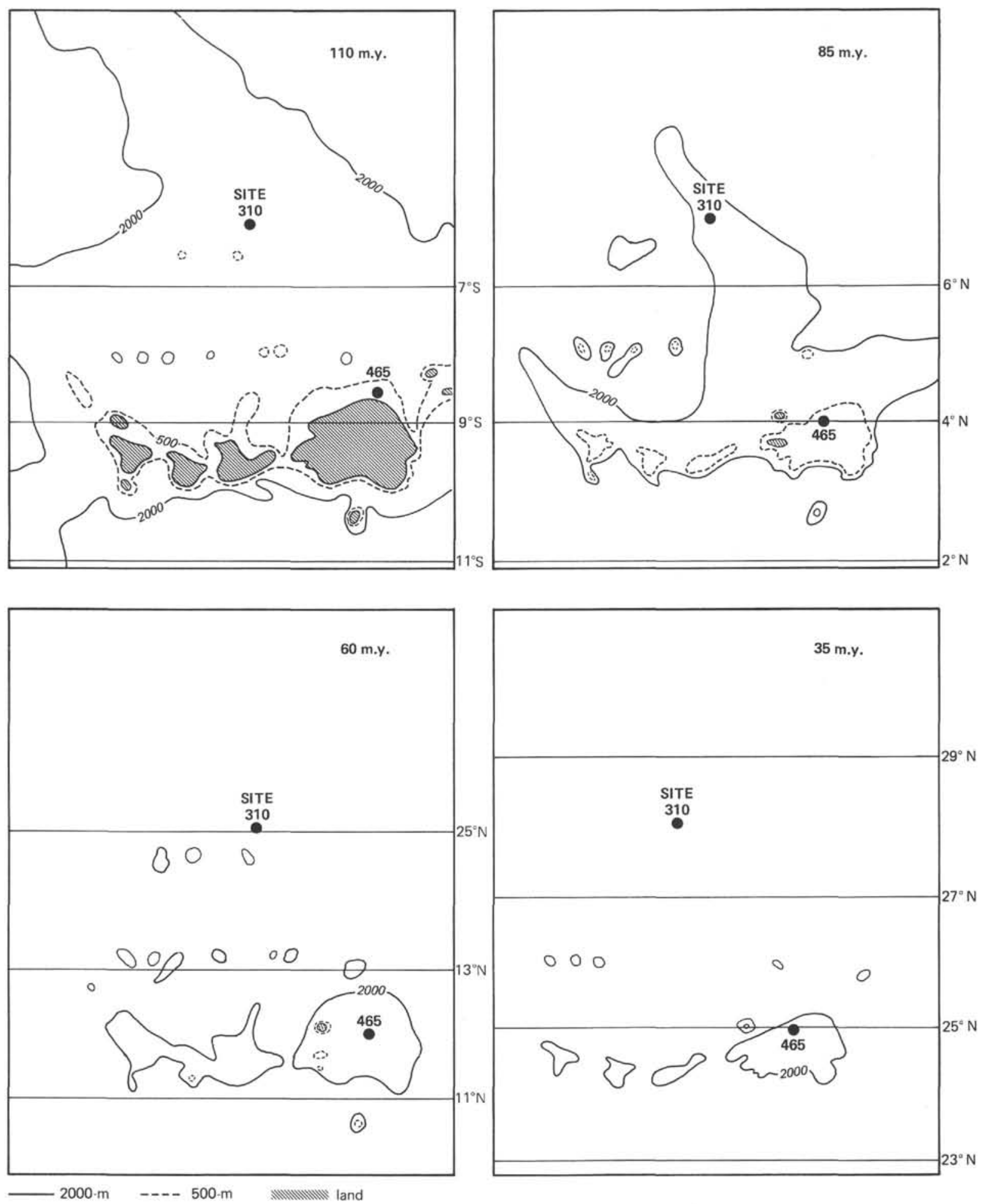

Figure 27. Paleogeographic and paleobathymetric position of Hess Rise during the past 110 m.y. The paleolatitude of Hess Rise has been reconstructed based on the plate-rotation model of Lancelot (1978). For modern bathymetry, see Figure 3.

the Mendocino Fracture Zone, which changed Emperor Trough from a spreading center into a long transform fault, and the triple junction changed from $r-r-r$ to ridge-fault-fault ( $\mathrm{r}-\mathrm{f}-\mathrm{f}$ ) (see fig. 14B of Larson and Chase, 1972). This configuration could remain stable only if the rates of slip on both transform faults (Emperor Trough and Mendocino Fracture Zone) were iden- tical. Apparently, the stability criteria were not satisfied, and the $\mathrm{r}-\mathrm{f}-\mathrm{f}$ triple junction subsequently evolved into another stable r-r-r triple point $80 \mathrm{~m}$.y. ago (see fig. 14C of Larson and Chase, 1972).

Carlson (1979) pointed out that the model proposed by Hilde, Isezaki, and Wageman (1976) was untenable, because it requires two simultaneous directions of mo- 

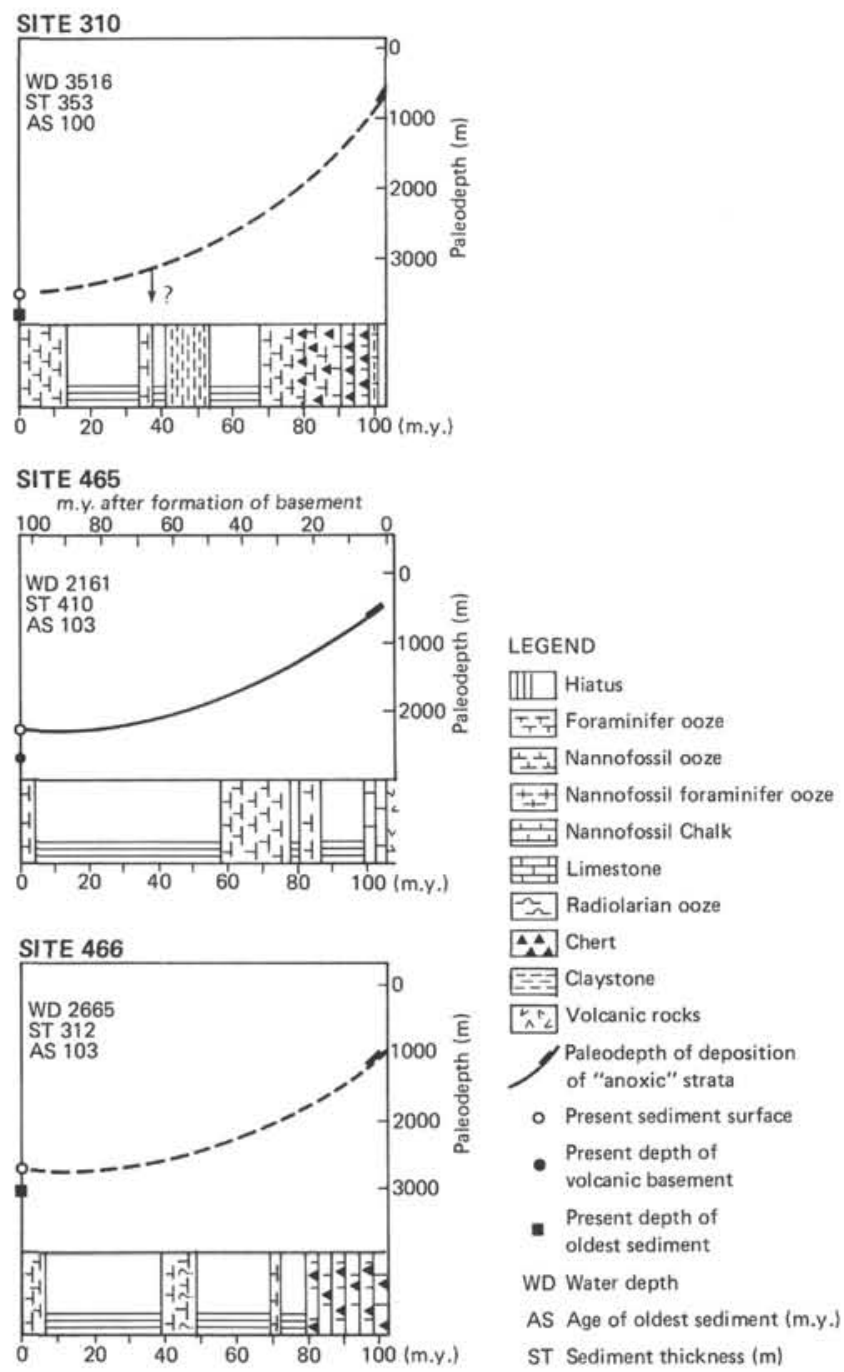

Figure 28. Reconstruction of the paleodepth of deposition of three deep-sea drill sites on Hess Rise. Reconstruction of the paleodepth of deposition is tentative, because we do not known when Hess Rise was formed in relation to the surrounding normal ocean crust; therefore, we do not know at which rate this oceanic plateau subsided. Paleontological evidence from Sites 465 and 466 (Boersma, this volume) suggests that the southern part of Hess Rise subsided considerably slower than young oceanic crust close to oceanic spreading centers.

tion between the Kula and Pacific Plates. For example, north-south spreading on the Kula-Pacific Ridge is well constrained by the north-south trends of the fracture zones south of the Aleutian Trench. Consequently, if Emperor Trough marks a plate boundary, then it must have been a spreading center (similar to that envisioned by Larson and Chase, 1972). There are no data to support such a model. Carlson's model satisfies the geometric constraints and has an additional plate, the three plates (Kula, Pacific, and unnamed plate) meeting at a stable ridge-trench-fault triple junction. This model requires that the Pacific Plate was consumed along a trench which grew longer at a rate of $5 \mathrm{~cm} / \mathrm{yr}$ because of the migration of the triple junction. The difficulty with this model is that 2000 to $2500 \mathrm{~km}$ of Pacific Plate would have been consumed by subduction along Emperor Trough between 110 and $60 \mathrm{~m} . \mathrm{y}$. ago, and an island arc should have developed in the approximate position of Hess Rise. We do not believe that Hess Rise was an island arc similar to those rimming the Pacific Ocean basin at the present time.

Farrar and Dixon (in press) proposed that Emperor Trough is much younger, and that it is part of a long transform fault system which split the Pacific Plate 67 to $40 \mathrm{~m} . \mathrm{y}$. ago, resulting in $1700 \mathrm{~km}$ of dextral offset. The entire system, named the Emperor Fracture Zone (EFZ) system, consisted of segments along the present trace of the Emperor Trough, along the Line Islands, and along the line of seamounts between southern Hess Rise and Hawaiian Ridge named the Volador lineament. These segments were joined by east-west spreading ridges along what are now southern Hess Rise, Necker Ridge, and the lineament capped by Horizon Guyot. The finite-angular-velocity vector describing the relative motion between the eastern and western Pacific plates is about $0.6^{\circ} / \mathrm{m}$.y. about a pole at $36^{\circ} \mathrm{N}, 70^{\circ} \mathrm{W}$; thereby, according to their calculations, the Meiji-Emperor and Emperor-Hawaiian bends date, respectively, the initiation (67 m.y. ago) and cessation (40 m.y. ago) of spreading on the Emperor Ridge system. Hypotheses presented by Farrar and Dixon are attractive because their model can account for (1) the present misalignment of the two sets of magnetic bights (Fig. 29), which is best explained by dextral offset along the Emperor Trough, (2) the abrupt truncation of eastern Pacific bathymetric lineaments against the Emperor Trough and Line Islands, and (3) the contrast in paleolatitude between the eastern and western Pacific indicated by paleomagnetic and sedimentologic studies. However, several weaknesses in their arguments can be pointed out. For example, they chose to align the Molokai Fracture Zone to the east with the prominent fracture zone system through the Hawaiian magnetic lineations (Fig. 29) that previously has been interpreted to be the western end of the Mendocino Fracture Zone. They considered the present-day alignment of this fracture zone in the Hawaiian lineations with the Mendocino Fracture Zone to be fortuitous. The ages of several features, both unknown and known, are possible additional weaknesses. For example, the age of the Volador Seamount Chain is not known, and there also should be lower Tertiary rocks along the south edge of Hess Rise where an east-west spreading-ridge segment was located. As they reported, the Line Island chain as a hotspot trace has not been documented by available data (e.g., Winterer, 1976), but the Cretaceous ages reported for that feature indicate that it is, at least for the most part, older than the early Tertiary ages needed to make it a transform fault on the Emperor Fracture Zone system. The known age of Horizon Guyot (Larson, Moberly, et al., 1975) also precludes its being part of an early Tertiary spreading ridge.

The event in the evolution of the North Pacific in the Cretaceous most challenging to explain is the migration of triple junctions from the northwest Pacific to the 


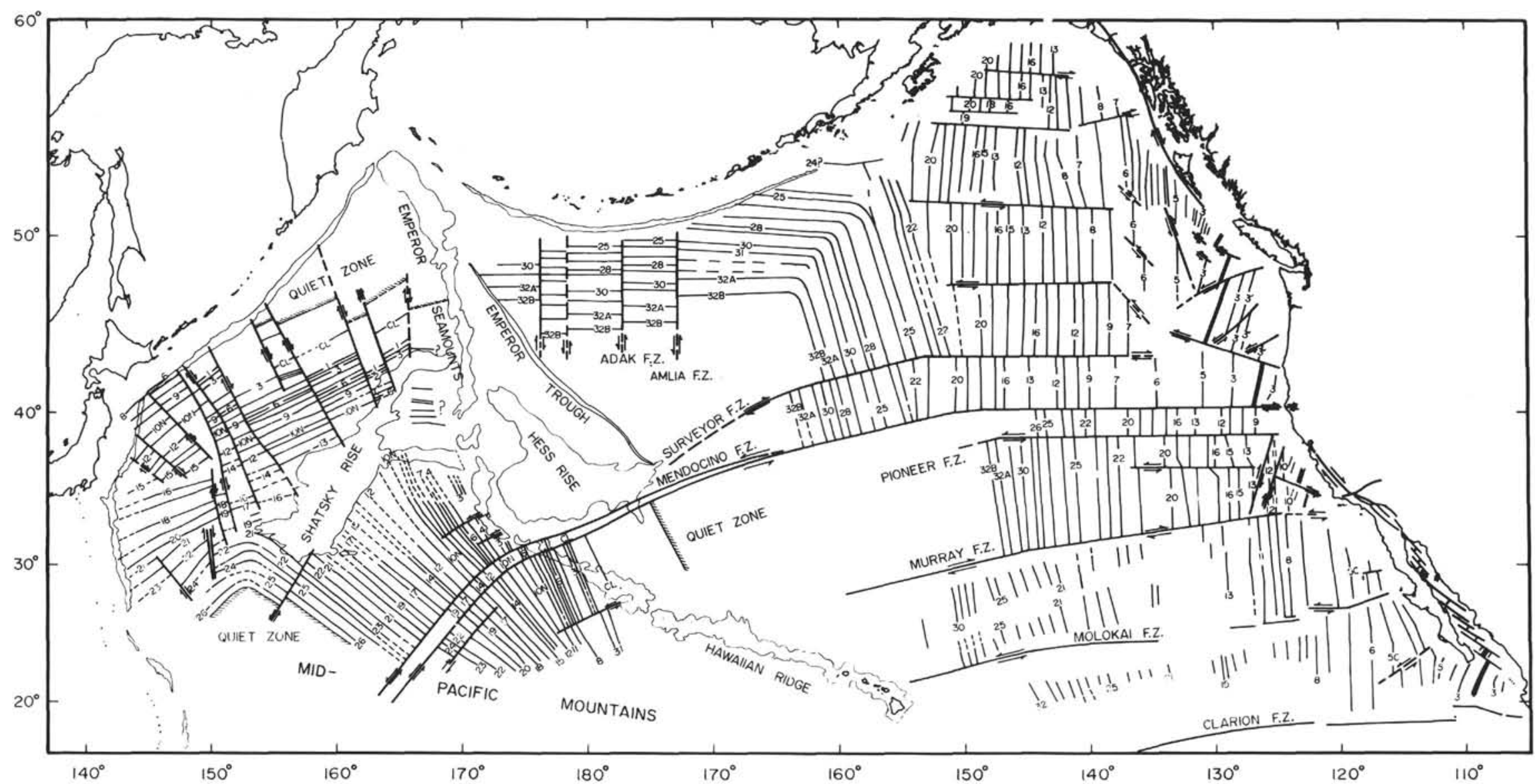

Figure 29. Magnetic-anomaly lineations in the North Pacific (from Hilde, Isezaki, and Wageman, 1976; permission to use the figure was granted by Hilde and the American Geophysical Union). 


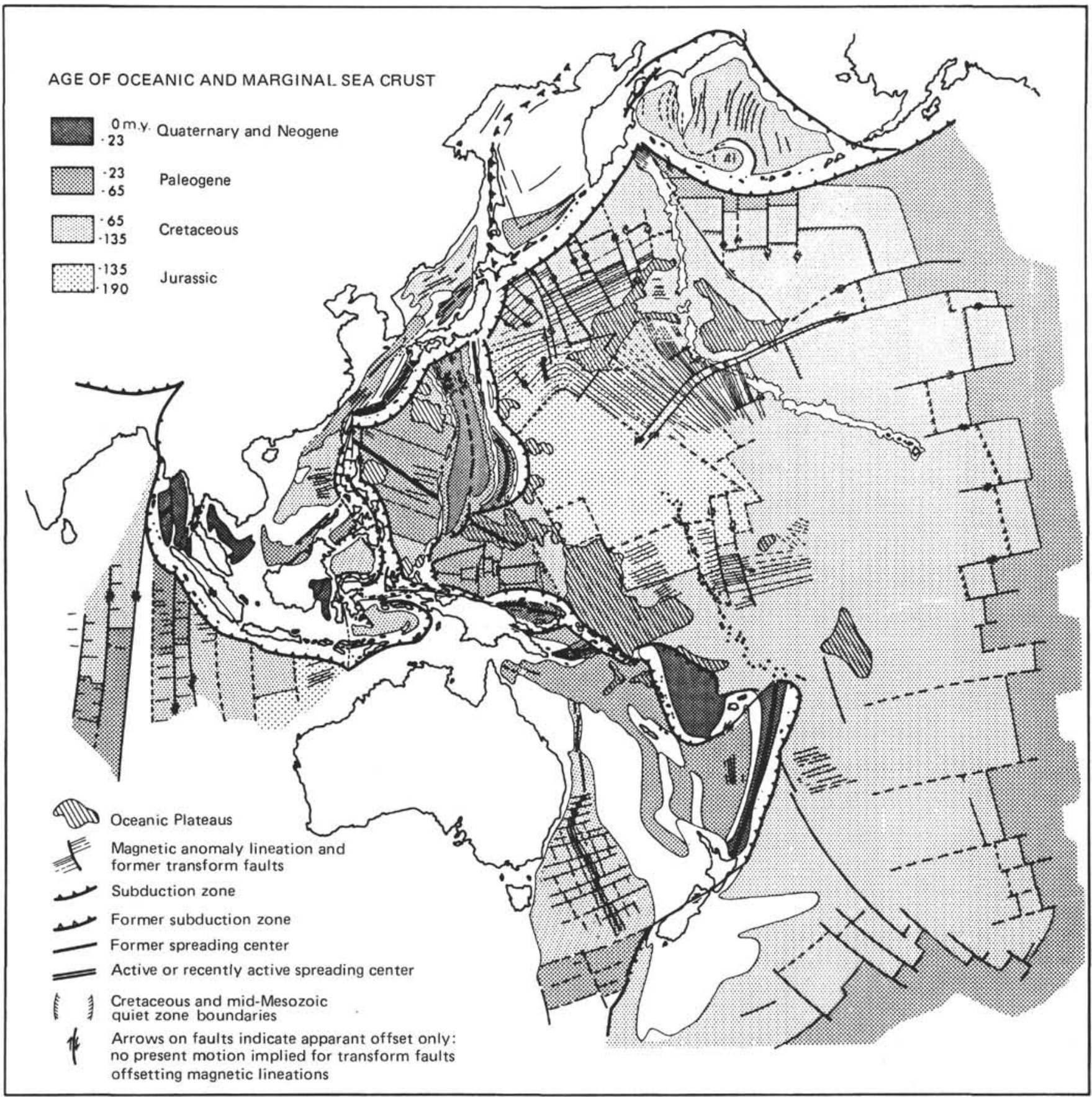

Figure 30. Age of the oceanic and marginal sea crust in the western Pacific (from Hilde, Uyeda, and Kroenke, 1977; permission to use the figure was given by Hilde and the Elsevier Scientific Publishing Company). Primary sources of data are the magnetic lineations and DSDP results.

northeast Pacific (Figs. 29 and 31). The Emperor Trough must have been a transform during at least part of the migration, but we do not understand its origin.

It would be presumptuous to throw out any model that can be used to explain the evolution of the North Pacific in general and Hess Rise specifically. Certainly, more data are needed before a truly acceptable model is proposed. At this time, the most acceptable model for the early evolution of Hess Rise is tied to a build-up of extrusives and attendant Layer 3 thickening at or near a triple junction, perhaps in association with a transform fault to account for the off-ridge alkalic volcanism (Windom et al., in press). Exactly how the triple junction migrated from the northwestern Pacific bight to the southeast is not known, but the least complicated way would be migration of the triple junction along a transform fault now either overprinted by the Emperor Seamount chain or part of the northwest-southeast arm of 


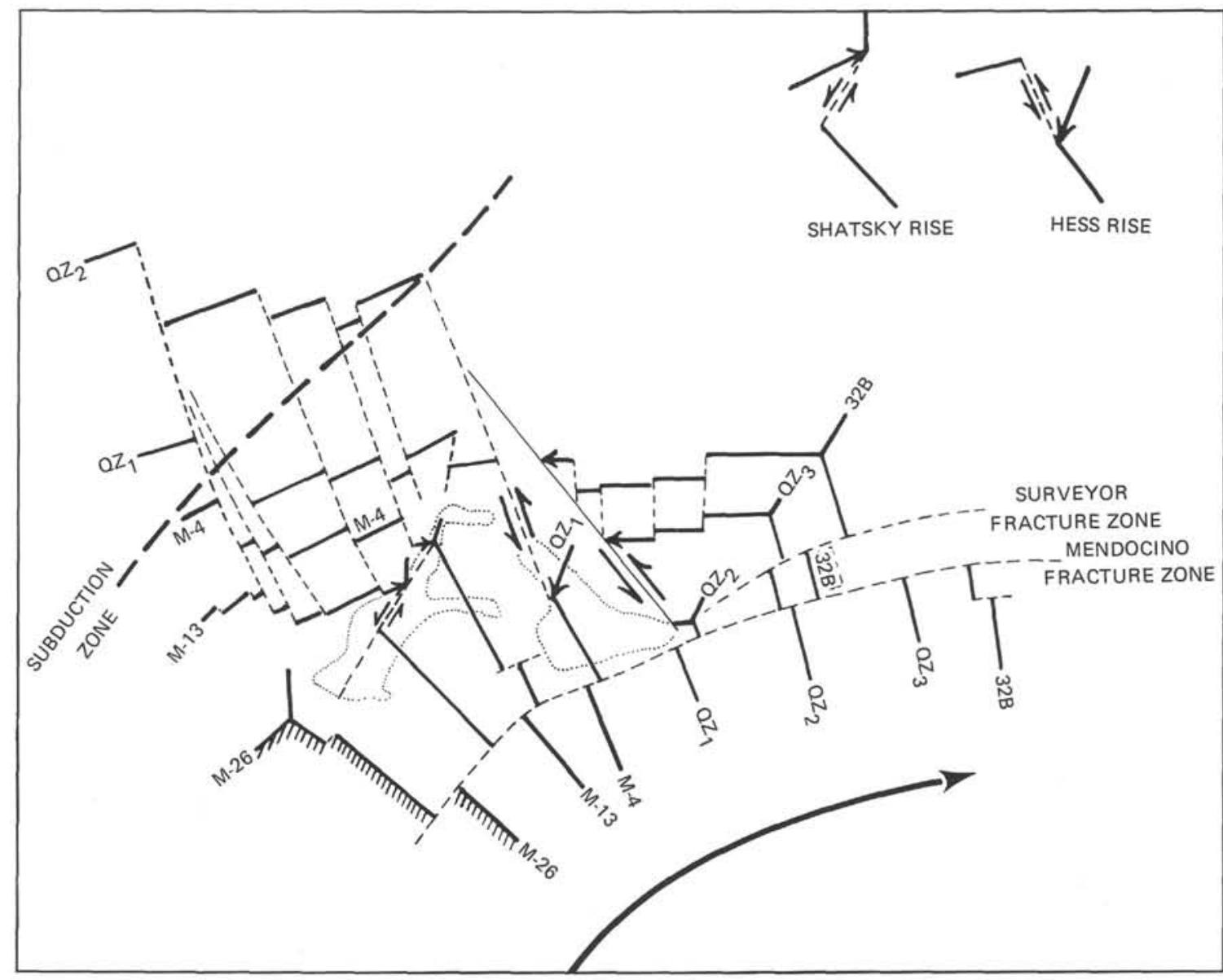

Figure 31. Proposed evolution of the North Pacific from mid-Mesozoic to Cenozoic time (from Hilde, Isezaki, and Wageman, 1976; permission to use the figure was given by Hilde and the American Geophysical Union). Quiet-zone lineations $\left(\mathrm{QZ}_{1}, \mathrm{QZ}_{2}\right.$, and $\left.\mathrm{QZ}_{3}\right)$ are imaginary. Arrows on Shatsky Rise and Hess Rise transform faults indicate motion for times $\mathrm{M}-13$ and $\mathrm{QZ} \mathrm{Z}_{1}$, respectively. The arrow on the Emperor Trough indicates motion of the Kula Plate on the east relative to the Pacific Plate on the west after time $\mathrm{QZ}_{2}$. The curved arrow indicates rotation of spreading directions relative to the northern Pacific Plate from mid-Mesozoic to Cenozoic time.

Hess Rise (Fig. 1). Thereby Emperor Trough would have to be a later feature and not important during the early tectonic evolution of Hess Rise.

\section{CONCLUSIONS}

Hess Rise probably formed at a triple junction between 116 and 95 m.y. ago, south of the Mid-Cretaceous equator. Parts of Hess Rise were above sea level as volcanic islands during the early part of its history; these islands were eroded and subsided below sea level as the Pacific Plate moved northward. Sediments that accumulated on the igneous crust of Hess Rise reflect both the subsidence and the northward movement as Hess Rise successively moved under tropical, subtropical, central, and subarctic surface water masses.

The topography of Hess Rise is closely related to the structure, which is dominated by normal faults. Grabens and horsts are common features, and the west and south sides of Hess Rise are bounded by steep fault scarps. Dominant fault trends are about $345^{\circ}$ on northern Hess Rise, and 039 to $060^{\circ}$ on southern Hess Rise. Many of the structures probably originated during the early development of Hess Rise, but changes in sediment thickness along some faults indicate continued movement during sediment accumulation. A major tectonic event may have occurred in the Late Cretaceous or early Tertiary, but the exact timing cannot be pinpointed.

Igneous rocks recovered from Hess Rise drill sites are similar to igneous rocks from several other oceanic plateaus and from many oceanic islands. A small amount of tholeiitic basalt was recovered from Site 464 on northern Hess Rise, but the highly altered nature of the rock made the chemical attributes nondiagnostic for distinguishing the original tectonic setting. Middle Cretaceous (Albian or older) igneous rocks recovered at Site 465 on southern Hess Rise consist of altered trachyte erupted either in shallow water or subaerially. Altered clasts of alkali basalt clasts at Site 466 apparently were recovered along an Upper Cretaceous-lower Eocene unconformity, although most of the clasts occurred within Upper Cretaceous calcareous ooze. Drilling may have caused down-hole contamination. The volcanic rocks probably were eroded from nearby islands that 
either had been tectonically uplifted to a position above sea level or were built by Late Cretaceous and(or) early Tertiary volcanism.

Major lithofacies recovered from the sites drilled on Hess Rise are limestone, pelagic clay, and calcareous ooze and chalk, with varying amounts of chert and siliceous microfossils. The pelagic clay was recovered from Sites 310 and 464, on central and northern Hess Rise, respectively. Most material in the pelagic-clay facies may be eolian, derived both from arid continental areas and island volcanoes. Excellent examples of progressive diagenetic changes from ooze to chalk to limestone were recovered on central (Site 310) and southern Hess Rise (Sites 465 and 466). Limestone of middle Cretaceous age contains as much as $8.6 \%$ organic carbon at Sites 465 and 466, on southern Hess Rise. These limestones accumulated on a part of the rise that was above the CCD and was also within a mid-water oxygen minimum as the rise crossed under the highly productive equatorial divergence.

Surface sediment on Hess Rise can be divided into three major facies: pelagic clay, marl, and calcareous ooze. A minor siliceous-fossil facies contains abundant diatoms and radiolarians mixed with variable amounts of calcareous microfossils and clay. Calcareous ooze generally occurs above about $\mathbf{3 0 0 0}$ meters water depth, and pelagic clay is found below 4000 meters; marl covers the sea floor between about 3000 meters and 4000 meters.

From correlations of the drilling and seismic-reflection data, it is apparent that there are three major acoustic units on Hess Rise which vary in composition, time, and space (thickness and geographic distribution). The lowest unit, which is generally opaque to the seismic systems used, corresponds to volcanic basement. Volcanic basement is basalt of Albian or Aptian age on northern Hess Rise (Site 464), and trachyte of Albian or Aptian age on southern Hess Rise (Site 465). The middle acoustic unit is Albian and Cenomanian chert, nannofossil chalk and ooze, limestone, and claystone at Site 464, and Albian and Cenomanian limestone, nannofossil chalk, and chert on southern Hess Rise at Sites 465 and 466 . On the central platform, the middle and upper acoustic units are difficult to separate; nannofossil ooze, nannofossil chalk and chert are the major lithologies and range from Albian or Cenomanian to present. The thin Eocene pelagic-clay unit cored at Site 310 probably separates the middle and upper acoustic units. The upper acoustic unit correlates with Upper Cretaceous to Recent nannofossil ooze, chalk, and chert on southern Hess Rise; on northern Hess Rise, it correlates with Upper Cretaceous to Recent pelagic clay. The upper unit probably is Eocene to Recent pelagic clay, nannofossil ooze, and marl on the central platform.

The presence of a large archipelago may have disturbed the equatorial current regime as Hess Rise moved northward thereby causing a wide area of high productivity in the surface waters. There would have been an increase in upwelling and, because of the large islands, a probable increase in nutrients from erosion.

\section{ACKNOWLEDGMENTS}

We are particularly grateful to the ship's crew, drilling crew, and DSDP scientific staff, who assisted us on the Glomar Challenger during Leg 62, and the shore-based DSDP staff who helped us during all stages of manuscript production. We thank Tom Aitken (LamontDoherty Geological Observatory) and Stuart Smith (Scripps Institution of Oceanography) for providing photographs of seismic-reflection profiles from cruises that traversed Hess Rise and Floyd McCoy (Lamont) and Phyllis Helms (Scripps) for providing piston-core descriptions. We appreciate the critical reviews of an early draft provided by James V. Gardner and Michael A. Fisher, which improved the manuscript. We also thank Lola Boyce, Louise Reif, and Juanita Mascardo for typing copies of this manuscript, and Myrtali Anagnostopoulos for drafting the illustrations.

\section{REFERENCES}

Alvarez, L. W., Alvarez, W., Asaro, F., et al., 1980. Extraterrestrial cause for the Cretaceous-Tertiary extinction. Science, 208:10951108.

Andrews, A. J., 1977. Low temperature fluid alteration of oceanic layer two basalts, DSDP Leg 37. Can. J. Earth Sci., 14:911-926.

Arthur, M. A., Dean, W. E., and Polastro, R., 1980. Oxic-anoxic and carbonate cycles in Cretaceous organic carbon-rich marine strata. Am. Assoc. Petrol. Geol. Bull., 64:671-672. (Abstract)

Arthur, M. A., and Schlanger, S. O., 1979. Cretaceous "oceanic anoxic events"' as causal factors in development of reef-reservoired giant oilfields. Am. Assoc. Petrol. Geol. Bull., 63:870-885.

Bass, M. N., 1976. Secondary minerals in oceanic basalt, with special reference to Leg 34, Deep Sea Drilling Project. In Yeats, R. S., Hart, S. R., et al., Init. Repts. DSDP, 34: Washington (U.S. Govt. Printing Office), 393-432.

Berger, W. H., Adelseck, C. J., and Mayer, L. A., 1976. Distribution of carbonate in surface sediments of the Pacific Ocean. $J$. Geophys. Res., 81:2617-2617.

Berger, W. H., and Winterer, E. L., 1974. Plate stratigraphy and the fluctuating carbonate line. In Hsü, K. J., and Jenkyns, H. C. (Eds.), Pelagic Sediments on Land and Under the Sea: Sedimentology, Spec. Publ., 1:11-48.

Brongersma-Sanders, M., 1957. Mass mortality in the sea. In Hedgpeth, J. W. (Ed.), Treatise on Marine Ecology and Paleoecology: Geol. Soc. Am. Mem., 67 (Pt. 1):941-1010.

1966. The fertility of the sea and its bearing on the origin of oil. J. Am. Assoc. Adv. Sci., 23:41-46.

Byers, C. W., and Larson, D. W., 1979. Paleoenvironments of Mowry Shale (Lower Cretaceous), western and central Wyoming. Am. Assoc. Petrol. Geol. Bull., 63:354-361.

Calvert, S. E., and Price, N. B., 1971. Upwelling and nutrient regeneration in the Benguela current, October, 1968. Deep Sea Res., 13; 505-523.

Cann, J. R., 1971. Major element variations in ocean-floor basalts. Philos. Trans. Roy. Soc. London, 268A:495-505.

Carlson, R. L., 1979. The Emperor Trough as a plate boundary: a kinematic problem. Papers presented at the Symposium on oceanic Plateaus, Texas A and M University, College Station, Texas, pp. 25-26.

Church, T. M., 1979. Marine barite. In Burns, R. G. (Ed.), Marine Minerals: Washington (Mineral. Soc. Am.), Short Course Notes, 6:175-209.

Dalrymple, G. B., Lanphere, M. A., and Clague, D. A., 1980. Conventional and ${ }^{40} \mathrm{Ar} /{ }^{39} \mathrm{Ar}$ ages of volcanic rocks from Ojin (Site 430), Nintoku (Site 432), and Suiko (Site 433) Seamounts and the chronology of volcanic propagation along the Hawaiian Emperor Chain. In Jackson, E. D., Koizumi, I., et al., Init. Repts. DSDP, 55: Washington (U.S. Govt. Printing Office), 659-676.

Davies, T. A., Clague, D. A., and Wilde, P., 1971. Preliminary report on Leg VII of ARIES expedition: geological investigations in the western North Pacific, July-August, 1971. Scripps Inst. Oceanogr. Ref. Ser., 71-27.

Dean, W. E., Barron, E. J., Boyce, R. E., et al., in press. Cretaceous black-shale deposition within an oxidized red clay, turbidite environment, southern Angola Basin, south Atlantic Ocean. Am. Assoc. Petrol. Geol. Bull. (Abstract) 
Dean, W. E., Gardner, J. V., Jansa, L. F., et al., 1978. Cyclic sedimentation along the continental margin of northwest Africa. In Lancelot, Y., Seibold, E., et al., Init. Repts. DSDP, 41: Washington (U.S. Govt. Printing Office), 965-989.

Dean, W. E., and Schreiber, B. C., 1978. Authigenic barite, Leg 41 Deep Sea Drilling Project. In Lancelot, Y., Seibold, E., et al., Init. Repts. DSDP, 41: Washington (U.S. Govt. Printing Office), 915-931.

Degens, E. T., and Ross, D. A. (Eds.), 1974. The Black Sea-geology, chemistry and biology. Am. Assoc. Petrol. Geol. Mem., 20.

Demaison, G. J., and Moore, G. T., 1980. Anoxic environments and oil source bed genesis. Am. Assoc. Petrol. Geol. Bull., 64: 1179-1209.

Detrick, R. S., Sclater, J. G., and Thiede, J., 1977. The subsidence of aseismic ridges. Earth Planet. Sci. Lett., 34:185-196.

Douglas, R. G., and Savin, S. M., 1975. Oxygen and carbon isotope analyses of Tertiary and Cretaceous microfossils from Shatsky and other sites in the North Pacific Ocean. In Larson, R. L., Moberly, R., et al., Init. Repts. DSDP, 32: Washington (U.S. Govt. Printing Office), 509-521.

Erickson, B. H., Naugler, F. P., and Lucas, W. H., 1970. Emperor Fracture Zone: a newly discovered feature in the central North Pacific. Nature, 225:53-54.

Farrar, E., and Dixon, J. M., in press. Early Tertiary rupture of the Pacific plate: $1700 \mathrm{~km}$ of dextral offset along the Emperor troughLine Islands lineament. Earth Planet. Sci. Lett.

Firstbrook, P. L., Finnell, B. M., Hurley, A. M., et al., 1979. Paleoceanic Reconstructions 160-0 Ma: Washington (National Sci. Found.).

Fischer, A. G., and Arthur, M. A., 1977. Secular variations in the pelagic realm. In Cook, H. E., and Enos, P. (Eds.), Deep Water Carbonate Environments: Soc. Econ. Paleontol. Mineral. Spec. Publ., 25:19-50.

Ganapathy, R., 1980. A major meteorite impact on the earth 65 million years ago: evidence from the Cretaceous-Tertiary boundary clay. Science, 209:921-923.

Gardner, J. V., Dean, W. E., and Jansa, L. F., 1978. Sediments recovered from the northwest African continental margin, Leg 41, DSDP. In Lancelot, Y., Seibold, E., et al., Init. Repts. DSDP, 41: Washington (U.S. Govt. Printing Office), 1121-1134.

Greene, H. G., 1980. Geophysical observations collected underway on Glomar Challenger-Leg 55. In Jackson, E. D., Koizumi, I., et al., Init. Repts. DSDP, 55: Washington (U.S. Govt. Printing Office), 789-800.

Hart, S. R., 1971. K, Rb, Cs, $\mathrm{Sr}$, and Ba contents and $\mathrm{Sr}$ isotope ratios of ocean floor basalts. Philos. Trans. Roy. Soc. London, 268A: 573-587.

Hilde, T. W. C., Isezaki, N., and Wageman, J. M., 1976. Mesozoic sea-floor spreading in the North Pacific. Am. Geophys. Union, Geophys. Monogr., 19:205-226.

Hilde, T. W. C., Uyeda, S., and Kroenke, L., 1977. Evolution of the western Pacific and its margin. Tectonophysics, 38:145-165.

Jackson, E. D., Koizumi, I., et al., 1980. Init. Repts. DSDP, 55: Washington (U.S. Govt. Printing Office).

Jenkyns, H. C., 1980. Cretaceous anoxic events: from continents to oceans. J. Geol. Soc. London, 137:171-188.

Lancelot, Y., 1978. Relations entre évolution sédimentaire et tectonique de la Plaque Pacifique depuis le Crétacé Inférieur. Société Géologique de France, Mémoire, 134.

Lancelot, Y., and Larson, R. L., 1975. Sedimentary and tectonic evolution of the northwestern Pacific. In Larson, R. L., Moberly, R., et al., Init. Repts. DSDP, 32: Washington (U.S. Govt. Printing Office), $925-939$.

Larson, R. L., and Chase, C. G., 1972. Late Mesozoic evolution of the western Pacific. Geol. Soc. Am. Bull., 38:3627-3644.

Larson, R. L., Lancelot, Y., Gardner, J. V., et al., 1975. Magnetic bathymetric, seismic reflection, and positioning data collected underway on Glomar Challenger, Leg 32. In Larson, R. L., Moberly, R., et al., Init. Repts. DSDP, 32: Washington (U.S. Govt. Printing Office), 393-427.

Larson, R. L., Moberly, R., et al., 1975. Init. Repts. DSDP, 32: Washington (U.S. Govt. Printing Office).
Matter, A., Douglas, R. G., Perch-Nielsen, K., 1975. Fossil preservation, geochemistry, and diagenesis of pelagic carbonates from Shatsky Rise, northwest Pacific. In Larson, R. L., Moberly, R., et al., Init. Repts. DSDP, 32: Washington (U.S. Govt. Printing Office), 891-921.

Moberly, R., and Larson, R. L., 1975. Mesozoic magnetic anomalies, oceanic plateau, and seamount chains in the northwestern Pacific Ocean. In Larson, R. L., Moberly, R., et al., Init. Repts. DSDP, 32: Washington (U.S. Govt. Printing Office), 945-957.

Moore, T. C., Heath, G. R., Kowsmann, R. O., 1973. Biogenic sediments of the Panama Basin. J. Geol., 81:458-472.

Morris, K. A., 1979. A classification of Jurassic marine shale sequences: an example from the Toarcian (Lower Jurassic) of Great Britain. Paleogeogr., Paleoclimatol., Paleoecol., 26:117-120.

Nemoto, K., and Kroenke, L. W., in press. Marine geology of the Hess Rise. Part I: bathymetry, surface sediment distribution, and environment of deposition. J. Geophys. Res.

Nesteroff, W. D., 1973. Petrography and mineralogy of sapropels. In Ryan, W. B. F., Hsü, K. J., et al., Init. Repts. DSDP, 13: Washington (U.S. Govt. Printing Office), 713-720.

Nixon, R. P., 1973. Oil source beds in Cretaceous Mowry Shale of northwestern interior United States. Am. Assoc. Petrol. Geol. Bull., 57:136-161.

Ryan, W. B. F., 1972. Stratigraphy of Late Quaternary sediments in the eastern Mediterranean. In Stanley, D. J. (Ed.), The Mediterranean Sea: Stroudsburg, Pa. (Dowden, Hutchinson, and Ross), pp. 149-169.

Ryan, W. B. F., and Cita, M. A., 1977. Ignorance concerning episodes of oceanwide stagnation. Mar. Geol., 23:197-215.

Scheidegger, K. F., and Stakes, D. S., 1977. Mineralogy, chemistry, and crystallization sequence of clay minerals in altered tholeiitic basalts from the Peru Trench. Earth Planet. Sci. Lett., 36: 413-422.

Schlanger, S. O., Jackson, E. D., et al., 1976. Init. Repts. DSDP, 33: Washington (U.S. Govt. Printing Office).

Schlanger, S. O., and Jenkyns, H. C., 1976. Cretaceous oceanic anoxic events causes and consequences. Geologie en Mijnbouw, 55: 179-184.

Shido, F., Miyashiro, A., and Ewing, M., 1971. Crystallization of abyssal tholeiites. Contr. Mineral. Petrol., 31:251-266.

Smit, J., and Hertogen, J., 1980. An extraterrestrial event at the Cretaceous-Tertiary boundary. Nature, 285:198-200.

Sun, S. S., Nesbitt, R. W., and Sharaskin, A., 1979. Geochemical characteristics of mid-ocean ridge basalts. Earth Planet. Sci. Lett., 44:119-128.

Thiede, J., Dean, W. E., and Claypool, G. E., in press. Oxygen deficient depositional paleoenvironments in the mid-Cretaceous tropical and subtropical central Pacific Ocean. Cretaceous Res.

Thiede, J., and van Andel, Tj. H., 1977. The paleoenvironment of anaerobic sediments in the late Mesozoic South Atlantic Ocean. Earth Planet. Sci. Lett., 33:301-309.

Vallier, T. L., Windom, K. E., Seifert, K. E., et al., 1980. Volcanic rocks cored on Hess Rise, western Pacific Ocean. Nature, 286: 48-50.

van Andel, Tj. H., Heath, G. R., and Moore, T. C., Jr., 1975. Cenozoic history and paleoceanography of the central equatorial Pacific Ocean. Geol. Soc. Am. Mem., 143.

Watts, A. B., Bodine, J. H., and Ribe, N. M., 1980. Observations of flexure and the geological evolution of the Pacific Ocean basin. Nature, 283:532-537.

Weissert, H., McKenzie, J., and Hochuli, P., 1979. Cyclic anoxic events in the Early Cretaceous Tethys Ocean. Geology, 7:147-151.

Windom, K. E., Seifert, K. E., and Vallier, T. L., in press. Basalt and trachyte from Hess Rise: implications for the origin of oceanic plateaus. J. Geophys. Res.

Winterer, E. L., 1973. Sedimentary facies and plate tectonics of equatorial Pacific. Am. Assoc. Petrol. Geol. Bull., 57:265-282. 1976. Anomalies in the tectonic evolution of the Pacific. Am. Geophys. Union Monogr., 19:269-278.

Winterer, E. L., Ewing, J. I., et al., 1973. Init. Repts. DSDP, 17: Washington (U.S. Govt. Printing Office). 